University of Nebraska - Lincoln

DigitalCommons@University of Nebraska - Lincoln

Agronomy \& Horticulture -- Faculty Publications

Agronomy and Horticulture Department

10-1949

\title{
Soil-Root Relationships of Certain Native Grasses in Various Soil Types
}

J. E. Weaver

University of Nebraska-Lincoln

R. W. Darland

Follow this and additional works at: https://digitalcommons.unl.edu/agronomyfacpub

Part of the Plant Sciences Commons

Weaver, J. E. and Darland, R. W., "Soil-Root Relationships of Certain Native Grasses in Various Soil Types" (1949). Agronomy \& Horticulture -- Faculty Publications. 494.

https://digitalcommons.unl.edu/agronomyfacpub/494

This Article is brought to you for free and open access by the Agronomy and Horticulture Department at DigitalCommons@University of Nebraska - Lincoln. It has been accepted for inclusion in Agronomy \& Horticulture -Faculty Publications by an authorized administrator of DigitalCommons@University of Nebraska - Lincoln. 


\title{
SOIL-ROOT RELATIONSHIPS OF CERTAIN NATIVE GRASSES IN VARIOUS SOIL TYPES
}

\author{
J. E. WEAVER \\ AND \\ R. W. Darland \\ University of Nebraska
}

Contribution No. 153 from the Department of Botany, University of Nebraska. This study was aided by a grant from the University Research Council, University of Nebraska. 
TABLE OF CONTENTS

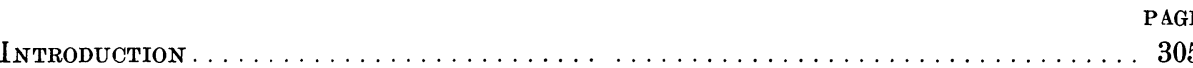

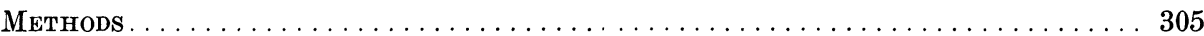

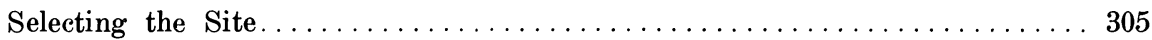

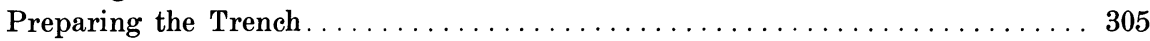

Marking Out the Monolith .......................... 306

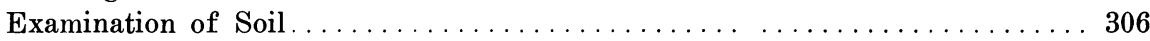

Preparing and Washing Away of the Soil .................. 307

Preparing the Roots for Photographing and Quantitative Study ......... 307

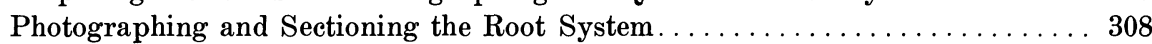

Examples of Root Distribution in Different Types of Soll. . . . . . . . . . . 308

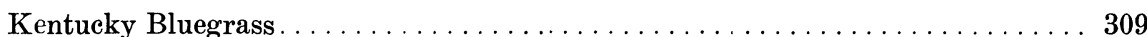

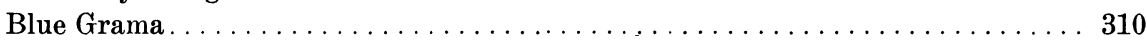

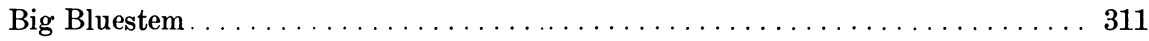

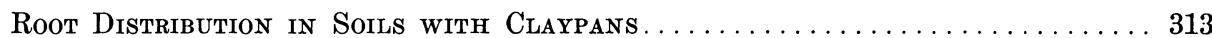

Western Wheat Grass in Crete Silty Clay Loam . . . . . . . . . . . . . . . 313

Western Wheat Grass in Butler Silt Loam . . . . . . . . . . . . . . . . . . . . 315

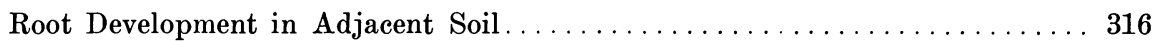

Western Wheat Grass in Scott Silty Clay Loam. . . . . . . . . . . . . . . 317

Western Wheat Grass in Rendzina Soil . . . . . . . . . . . . . . . . . . . 319

Root Distribution in Meliow Loess Soils. . . . . . . . . . . . . . . . . . 320

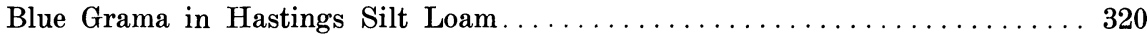

Blue Grama in Colby Silt Loam . . . . . . . . . . . . . . . . . . . . . . . . 321

Buffalo Grass in Holdrege Silt Loam. . . . . . . . . . . . . . . . . . . . . 322

Buffalo Grass in Wabash Silt Loam. . . . . . . . . . . . . . . . . . . . . . 323

Buffalo Grass in Sherman Silt Loam. . . . . . . . . . . . . . . . . . . . . . . . 324

Various Species in Azonal Soll of the Loess . . . . . . . . . . . . . . . . . . . 325

Blue Grama . . . . . . . . . . . . . . . . . . . . . . . . . . . . . 325

Buffalo Grass . . . . . . . . . . . . . . . . . . . . . . . . . . . . . . . . . 325

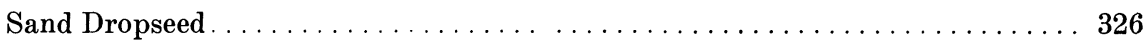

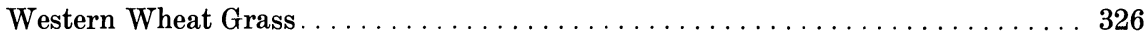

Purple Three-Awn . . . . . . . . . . . . . . . . . . . . . . . . . . . . . . . . 327

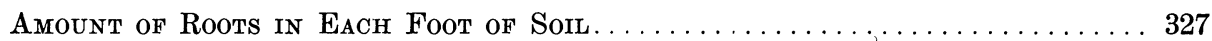

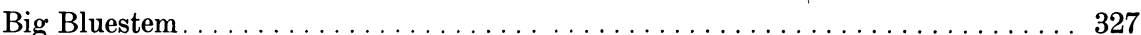

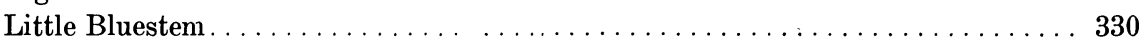

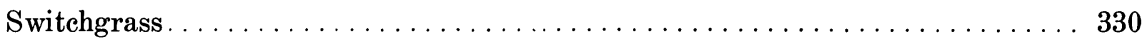

Side-Oats Grama . . . . . . . . . . . . . . . . . . . . . . . . . . . . . . . . . . . . 330

Kentucky Bluegrass . . . . . . . . . . . . . . . . . . . . . . . 331

Western Wheat Grass . . . . . . . . . . . . . . . . . . . . . . . . . 331

Blue Grama . . . . . . . . . . . . . . . . . . . . . . . . . . . . . . . . 331

Buffalo Grass . . . . . . . . . . . . . . . . . . . . . . . . . . . . . . 332

Percentage of Roots in Each Major Soll Horizon . . . . . . . . . . . . . . . 332

Drscussion $\ldots \ldots \ldots \ldots \ldots \ldots \ldots \ldots \ldots \ldots \ldots \ldots \ldots \ldots \ldots \ldots$

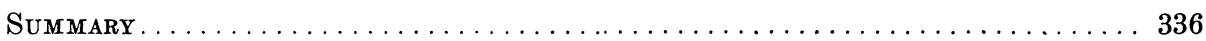

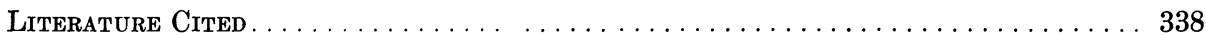




\section{SOIL-ROOT RELATIONSHIPS OF CERTAIN NATIVE GRASSES IN VARIOUS SOIL TYPES}

\section{INTRODUCTION}

Knowledge of the soil as a medium for the growth of roots has increased very greatly in the past three decades. Earlier studies on the root depth and distribution of native midwestern range and pasture grasses were made with only minor consideration of specific soil types or soil horizons (Weaver 1919, 1920 ; Sperry 1935; Albertson 1937). The objectives of these early studies were to ascertain the general relationships of roots to soil and to each other as regards spread, depth, and degree of development in the same community and in different and widely separated units of vegetation. Some attention was given to the response of root systems to the great drought (Weaver \& Albertson 1943). These studies formed a background for similar studies of crop plants (Weaver, Jean, \& Crist 1922; Jean \& Weaver 1924; Weaver 1926; Weaver \& Bruner 1927).

With the rapid development of soil science and much emphasis on the role of vegetation, especially grasses, in soil formation, a distinct need has arisen for a better understanding of the intimate relations of roots and soil. A beginning was made by Hanson \& Whitman (1938) in their study of the characteristics of major grassland types in western North Dakota. They observed the abundance and depth of roots in the several soil types. Study has been made of the quantities of organic materials provided to the soil by the mass of grass roots, and the rate at which they are formed (Weaver \& Zink 1946; Weaver, Hougen, \& Weldon 1935). The quantity of living underground materials, especially in the upper portion of the soil, has been ascertained (Weaver \& Harmon 1935; Shively \& Weaver 1939). Some information on the length of life of individual roots has been obtained (Weaver \& Zink 1946a) as well as the length of time required in grassland for roots to decompose and return to the soil (Weaver 1947). The effects of grazing on the root systems of several range grasses have also been ascertained (Weaver \& Darland 1947).

A new method has been devised which consists of obtaining representative samples of entire root systems, of studying the intimate relations of roots and soils, and of measuring root production quantitatively at various soil levels. This, together with more exact mapping of soils, a better understanding of the relationships of one soil type to another, and especially the greater accuracy and detail with which soil profiles are now described, makes it possible to ascertain more definite relationships between the roots of grasses and the soil in which they grow.

\section{METHODS}

The method of obtaining samples is a modification of the direct or trench method (Weaver 1926) which has been employed successfully over a period of several decades. It consists in the digging of a trench to the desired depth in a particular soil and the obtaining of a single undisturbed column or monolith of soil extending from the surface well into the "C" horizon and often of such length ( 3 to 5 feet) as to contain the longest roots of the native grasses in unbroken sod. The monolith should be of such dimensions that it can be removed from the trench and transported without special equipment. Particularly it should contain a representative sample of roots that are not too massive for careful separation from the soil by means of washing nor too abundant to reveal detailed distribution and density at the several soil levels.

Strong boxes without tops were made of $7 / 8$-inchthick planed boards of white pine. The bottom consisted of a single board a foot (actually $11.75 \mathrm{in}$.) in width and 3, 4, or 5 feet long. To this board, sides of similar material were fastened with nails and screws in such a manner that the 11.75-inch-wide box had an inside height of exactly 3 inches. One end was left open. Appropriate cleats of wood fastened to the bottom with screws effectually prevented warping and added much rigidity. The boxes were kept well painted. In use, a box was placed on end with the open end up, to contain the soil monolith which was 11.75 inches wide, 3 inches thick, and 3 to 5 feet in length.

\section{Selecting the Site}

Studies were made in arcas of native grassland in the eastern half of Nebraska and in northern Kansas. The histories of these prairies were well known by the writers. The prairie grasses were disturbed only by annual mowing, unless pasturing is indicated. Soil maps of the several counties were consulted and the type of soil, or its variation where samples were obtained, was carefully checked by professional soil examiners. The plan followed was to obtain monoliths within pure stands of certain species of grasses in a wide variety of soils. In all, 33 monoliths were taken with 10 species of grasses in 16 soil types.

\section{Preparing the Trench}

After a site with apparently normal development of vegetation was chosen, tarpaulins were spread on the ground by the sides of the place selected for digging. When soil was placed on these it greatly facilitated refilling the trench and reduced damage 
to the vegetation. The soil-root relations were observed as far as possible, and the root depth was noted as the soil was removed. Where a single monolith was taken, a trench 3 feet wide and about 4 feet long was convenient. But where two or more monoliths were to be taken, larger trenches were excavated. The depth, which was determined largely by the root length, was usually a foot deeper than the longest roots (3 to $5 \mathrm{ft}$.) in the monolith. The side walls were kept nearly vertical, despite the directions taken by some roots, since in prairie grasses most roots usually pursue a vertically downward course.

\section{Marking OUt the Monolith}

Beneath the particular sample of grass, previously selected and left undisturbed in the side wall, the wall of the trench was made smooth and vertical, as shown by a plumb line. A box was then placed on end, with the closed end downward. The open top was placed against the trench wall, the upper end just reaching the soil surface. An impression of the sides and end of the box was made on the wall of the trench by tapping the bottom of the box vigorously with a four-pound sledge hammer. The box was then removed and the soil column marked out with butchers' knives with rigid blades. Then the soil on the sides and below these marks was removed by means of knives and spades until the monolith protruded from the trench wall, the bottom and sides extending outward at least 3 inches. Next the box was fitted tightly over the monolith and the bottom and lower end of the box were braced to hold this soil mass in place. Finally the soil on the inner, attached face of the monolith was cut away by work- ing inward with knives and spades from each side. The soil was not cut close to the top of the box, but a V-shaped ridge of soil protruded throughout its length. This was a part of the sample when the braces were removed and the monolith was lifted out of the trench. The sample was placed in a truck, covered and kept damp to avoid serious eracking, until it was taken to the laboratory for an examination of the profile. Usually several monoliths were obtained on a single field trip.

\section{Examination of Soll}

The V-shaped ridge of soil protruding from each monolith was used in an examination of the profile. A complete description included not only the depth of the main soil horizons and the subdivision of these into their minor parts, but also the color, texture, structure, consistence, and $\mathrm{pH}$ of each subdivision. Complete descriptions were made of nearly all of the soil types; a few were somewhat abbreviated. The examination of a soil after some drying has distinct advantages. Soil may easily be moistened to compare its characteristics in a wet condition. Correlations of soils and descriptions of the profiles were made by James Thorp, W. I. Watkins, and B. H. Williams of the Division of Soil Survey, U. S. Department of Agriculture, and the Conservation and Survey Division, University of Nebraska. The authors are deeply grateful to them for this service. A photograph showing the root distribution in each of the soil types has been submitted to be filed with the official description of the soil. The soil types are numbered consecutively in this paper to permit ready reference to them. Table 1 contains data on a soil in monoliths with three

TABLE 1. Description of a monolith sample of (1) Sharpsburg silty clay loam, ${ }^{1}$ taken in a ravine in the ecological experimental prairie 3.5 miles northwest of the University of Nebraska in Lincolr.

\begin{tabular}{|c|c|c|c|c|c|c|c|}
\hline \multirow[b]{2}{*}{ Horizon } & \multirow[b]{2}{*}{ Depth } & \multicolumn{2}{|c|}{ CoLoR $^{2}$} & \multirow[b]{2}{*}{ Texture } & \multirow[b]{2}{*}{ Structure } & \multirow{2}{*}{$\begin{array}{c}\text { Consistence } \\
\text { (moist) }\end{array}$} & \multirow{2}{*}{$\begin{array}{l}\mathrm{pH} \text { by } \\
\text { Soiltex }\end{array}$} \\
\hline & & Dry & Moist & & & & \\
\hline$A_{1-1}$ & $0-7$ & $\begin{array}{l}\text { Very dark gray } \\
10 Y \mathrm{R} 3 / 1\end{array}$ & $\begin{array}{l}\text { Very dark brown } \\
\text { or black } \\
10 \mathrm{YR} 2 / 1.5\end{array}$ & Clay loam & $\begin{array}{l}\text { Fine } \\
\text { granular }\end{array}$ & Friable & 6.5 \\
\hline$A_{1-2}$ & $7-12$ & $\begin{array}{l}\text { Dark grayish } \\
\text { brown } \\
\text { 10YR } 2.5 / 2\end{array}$ & $\begin{array}{l}\text { Very dark brown } \\
10 \mathrm{YR} 2 / 2\end{array}$ & Clay loam & $\begin{array}{l}\text { Medium or } \\
\text { coarse } \\
\text { granular }\end{array}$ & Friable & 6.5 \\
\hline $\mathrm{B}_{1}$ & $12-18$ & $\begin{array}{l}\text { Grayish brown } \\
\text { 10YR 4/2 }\end{array}$ & $\begin{array}{l}\text { Dark grayish } \\
\text { brown } 10 \mathrm{YR} 3 / 2\end{array}$ & $\begin{array}{l}\text { Light }^{3} \text { silty } \\
\text { clay loam }\end{array}$ & Fine blocky & $\begin{array}{l}\text { Slightly } \\
\text { plastic }\end{array}$ & 6.5 \\
\hline $\mathrm{B}$ ? & $18-28$ & $\begin{array}{l}\text { Brown } \\
\text { 10YR 4/3 }\end{array}$ & $\begin{array}{l}\text { Dark brown } \\
10 \text { YR } 3 / 3\end{array}$ & $\begin{array}{l}\text { Silty clay } \\
\text { loam }\end{array}$ & Blocky & $\begin{array}{l}\text { Moderately } \\
\text { plastic }\end{array}$ & 6.5 \\
\hline $\mathrm{B}_{3}$ & $28-48$ & $\begin{array}{l}\text { Yellowish } \\
\text { brown 10YR 5/4 }\end{array}$ & $\begin{array}{l}\text { Dark yellowish } \\
\text { brown 10YR 4/4 }\end{array}$ & Silt loam & $\begin{array}{l}\text { Ill-defined } \\
\text { blocky }\end{array}$ & Friable & 6.5 \\
\hline$D_{1}$ & $48-66$ & $\begin{array}{l}\text { Yellowish } \\
\text { brown 10YR 5/4 }\end{array}$ & $\begin{array}{l}\text { Dark yellowish } \\
\text { brown 10YR 4/4 }\end{array}$ & $\begin{array}{l}\text { Silt loam con- } \\
\text { taining thin } \\
\text { lenses of } \\
\text { fine sand }\end{array}$ & $\begin{array}{l}\text { Massive or } \\
\text { somewhat } \\
\text { stratified }\end{array}$ & Friable & 6.5 \\
\hline
\end{tabular}

1This soil is mapped as Carrington soil, but can be considered only as a mapping inclusion; till from which the Carrington soils were formed lies below the solum

2Provisional Soil Survey color names, based on standard Munsell color charts; e.g., 10YR 5/2 means: hue is 10 yellow-red; value on lightness scale is 5; chroma saturation is 2 . The color names are those of common usage. 
different species taken from the walls of one trench. To conserve space the descriptions of soils that follow are presented in paragraph form rather than in tables.

Explanation of letters representing soil horizons are as follows:

$A_{1}$ The dark upper part of the uppermost horizon. Usually high in organic matter.

$A_{2}$ The lower part of the uppermost horizon of the soil that is leached, definitely lighter colored than the $A_{1}$, and lower in organic matter.

A $_{3}$ A transitional horizon, usually with more clay than horizons above and less clay than the $\mathrm{B}$ horizon. Usually thin.

$\mathrm{B}_{1}$ A transitional horizon with more clay than $\mathrm{A}$. Usually thin.

$B_{2} \quad$ A subsoil horizon with much more clay than the A horizon, and usually with much less organic matter.

$\mathrm{B}_{3} \quad \mathrm{~A}$ horizon transitional between the $\mathrm{B}_{2}$ and $\mathrm{C}$ or parent material.

$\mathrm{C}_{1}, \mathrm{C}_{2}$, etc. Parent material in various stages of weathering.

D horizons are materials beneath the soil that are different from parent material.

Each of the horizons may have subdivisions: e.g., $A_{1-1}, A_{1-2}, A_{2-1}, A_{2-2}, B_{2-1}, B_{2-2}$, etc.

One or more horizons are missing from some soils.

Preparing and Washing Away of the SoIl

Upon completion of the soil descriptions the excess soil was cut away even with the sides of the box so that the broad monolith was exactly 3 inches thick. It was then submerged in a large tank of water. Here it was suaked for a period of 2 to 5 days, depending upon soil type. Sometimes after the soil in the top of the box had been washed away the remainder was again soaked; then further washed, and soaked again. In washing, the box was placed at an angle of 10 degrees, the tops of the plants always being highest.

A flaring rose nozzle attached to a garden hose was employed. It spread the water uniformly through 107 small apertures and thus reduced the pressure of the water on the roots in any one place. The amount of water pressure used varied with the soil type and with the horizons in the same type. Too much pressure can easily ruin the root system. The rule was to use just enough pressure to gently remove the soil. The writers nearly always worked together in washing. Often it was necessary to wash the soil away under water and even then the more delicate roots had to be protected by the hand. All the soil removed was caught on a series of screens of 15 meshes per inch. Only a very few loose roots, usually a small fraction of 1 percent by weight, were found on the screen. These were roots that had entered the monolith from the side and did not intertwine with the main root mass sufficiently to be held in place. In fact, it was not the loss of roots but keeping the root pattern undisturbed that required the most careful attention.

The examination of soil-root relations under a shallow layer of water while washing reveals many features since the soil is slowly removed and new soil constantly comes into view. An exposed main root may be followed easily throughout its entire length, the branching being clearly revealed, and some of the details of soil-root relations examined.

Where the soil of the $C$ horizon was easily removed but that of the B horizon was very compact, it was sometimes necessary completely to remove the $A$ horizon by washing, then the refractory $B$ layer, leaving the roots in the- $\mathrm{C}$ horizon protected by the soil until this had been accomplished. Otherwise they would have been injured by the uverflow of soil and water. Sometimes the granules in a blocky soil structure could be removed more easily by carefully loosening them with an ice pick. Efficiency and success were gained only by experience. But one felt well repaid for the time spent when after 3 to 5 hours the complete root system alone was left in almost perfect sondition in the bottom of the box.

\section{Preparing the Roots for Photographing and Quantitative Study}

The network of roots was placed on a large, smooth, painted board which was kept wet and tilted at an angle of 10 degrees. One end of the board was placed in a sink. A thin sheet of water was kept flowing over the board continuously while any tangled roots were separated by means of dissecting needles and a hand spray. They separated readily and assumed their natural position only as long as they were kept under water. Sometimes this was accomplished by placing a weighted board in the bottom of a shallow tank of water and letting the roots spread into their normal position and then slowly siphoning off the water until the root system lay spread out on the board. In a few instances where there were tangled root fragments, it was necessary to float them in a separate container of water and then replace them in position on the root system. Of course, much time was saved by keeping the roots from getting tangled as the soil was removed by a proper system of washing.

All excess water was removed by means of blotters from the roots and the board. The roots were then covered with moist newspapers. At this stage and in this condition they could be kept for several days. A mounting board of light plywood, covered with black felt securely tacked in place, was inverted and placed over the root system after the newspapers were removed. The two boards were held firmly together while they were inverted. The end of the painted board near the top of the root system was then raised slightly. Usually the roots did not adhere to this board but lay on the black felt. If they did adhere they were loosened by using the smooth edge of a yardstick. After removal of the top board the roots were covered with damp paper and pressed firmly with the hand onto the felt. The crown was anchored by means of a few small nails driven into the mounting board. Then the entire mount was placed in a vertical position for photographing. 
Photographing and Sectioning the Root System

Photographs were made by the University of Nebraska Photographic Laboratory. The lighting was done by electro-flash units, one unit being placed

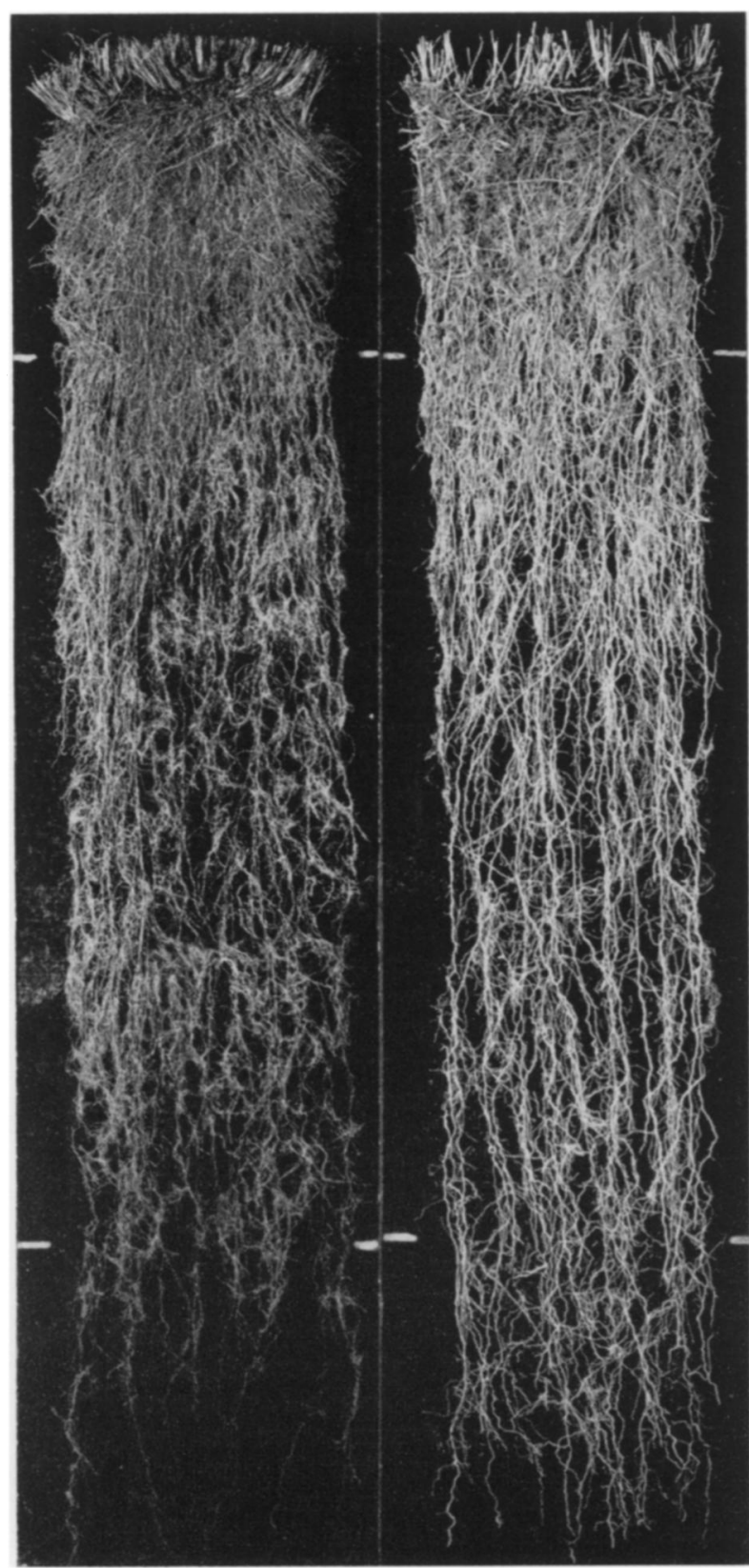

Fig. 1. Root system of little bluestem (Andropogor: scoparius) at left, and switchgrass (Panicum virgatum) at right, taken from 5 -foot monoliths with soil profile as shown in Table 1. The shallower rooted bluestem (about 5 feet) has a greater concentration of materials in the A horizon (0-12 in., above upper lines) than the 10foot-deep switchgrass. But bluestem has only 38 percent as much root-weight as switehgrass in the $B$ horizon (12-48 in., between the lines). In this and following figures, the width of the root system is 12 inches. on each side of the camera. The writers are greatly indebted to Mr. W. Hoffman and to others of his staff for this excellent service (Fig 1).

The root system was then sectioned in such a manner that the oven-dry weight at $100^{\circ} \mathrm{C}$. could be ascertained for each 6-inch or foot depth and also for each of the major soil horizons. For example, where the A horizon was between 0 and 7 inches and the $B$ between 7 and 22 inches, the root system was cut and weighed as follows: 0-6 inches, 6-7, 7-12, 12-22, 22-24, and 24-36 inches. In this work the underground materials in the surface 6 inches, whether roots, rhizomes, or stem-bases, are designated as roots. No attempt was made to separate roots from other plant materials.

In concluding the description of the method, the writers wish to state that it may seem long, tedious, and laborious. This we acknowledge. It must be judged solely by the results obtained.

\section{EXAMPLES OF ROOT DISTRIBUTION IN DIFFERENT TYPES OF SOIL}

The root distribution of three species of grasses in three different soil types near Lincoln, Nebraska, will be used first to illustrate some soil-root relationships. These were among the first of the 33 monoliths examined. The grasses are Kentucky bluegrass (Poa pratensis), blue grama (Bouteloua gracilis), and big bluestem (Andropogon furcatus) ${ }^{1}$

One group of monoliths was taken from an upland pasture adjoining Pioneer Park on the west and a second (except for blue grama) in an adjacent lowland. The third lot was taken from lowland in the ecological experimental prairie 3.5 miles northwest of the University of Nebraska.

The first monoliths were from Carrington silty clay loam. It is an old soil developed on glacial drift before the Peorian loess was deposited upon it. The A horizon is shallow (0-7 in.). The soil had been trampled by stock, and there was much compaction. Penetration of water was poor. The third foot in the reddish, clayey subsoil, except the upper two inches, was filled loosely with rock and pebbles from 2 inches to $1 / 16$-inch in diameter. Below 3 feet the hard, dry, pebble-filled soil was difficult to remove even with a hand pick.

\section{CARRINGTON SILTY CLAY LOAM}

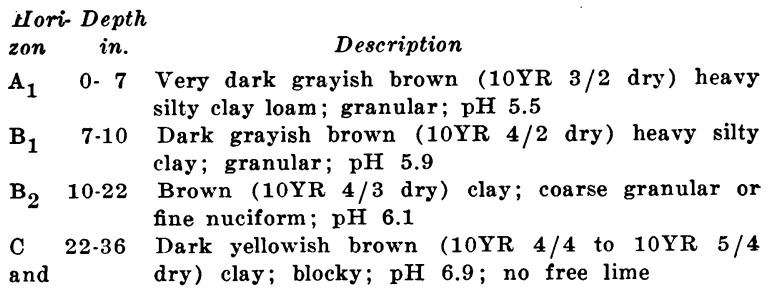

The monoliths were taken on the nearly level hilltop. Each kind of grass grew in locally pure stands. The two shorter grasses had been subjected to graz-

i Nomenclature of the grasses is according to Hitchcock's "Manual of the Grasses of the United States." 
ing, but big bluestem in a closely adjacent area had been protected from grazing.

The second excavations were made in a large, lightly grazed pasture at the foot of the hill and only a quarter of a mile distant. They were in Wabash silty clay loam. This is a young alluvial Wiesenboden (moist meadow) soil with only slight development of the profile. Changes are gradual with increase in depth.

\section{WABASH SILTY CLAY LOAM}

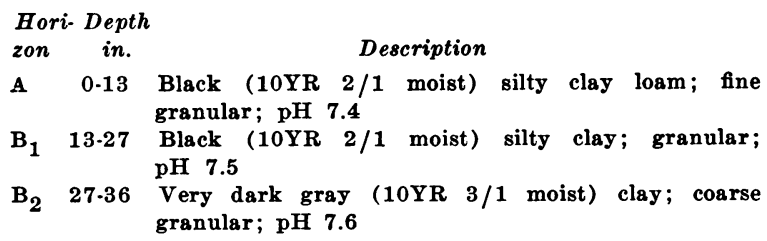

This soil had much fine material from deposits of calcareous loess which had been washed in from the upland. A weak columnar structure was found at depths of 26 to 36 inches. Nutlike blocks of soil usually 0.25 to 1 inch in the long axis, but often larger, occurred. The main cracks were vertical and often 12 to 14 inches long. This soil was moist throughout and was removed with little difficulty to a depth of 5 feet where it became wet.

A third lot of monoliths was taken from a well drained lowland in the experimental prairie in Judson silt loam. The native vegetation was not disturbed except by annual mowing in fall. The $A$ horizon of the granular silt loam is 20 inches deep. While it is a fairly "heavy" soil, a trench was dug to 5 feet in depth with no unusual difficulty. The soil is developed in silty colluvium and perhaps loess in the lower layers. It lies between the Sharpsburg soils developed from loess of the uplands, and Wabash soils of the alluvial bottomlands.

\section{JUDSON SILT LOAM}

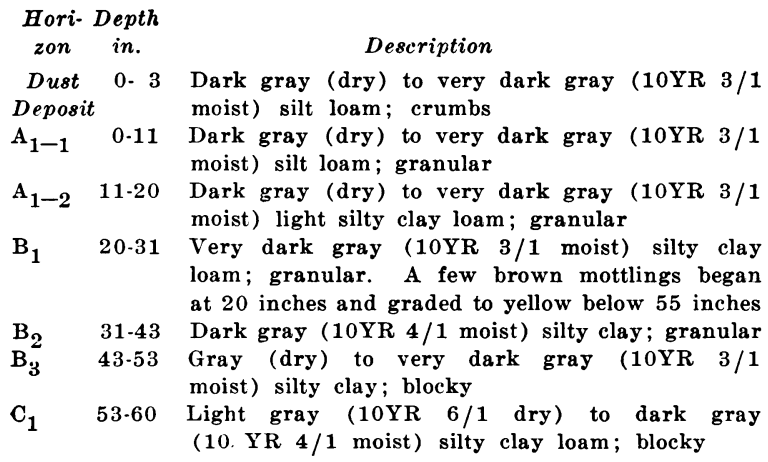
at 20 inches and graded to yellow below 55 inches

The soil is slightly acid to neutral in reaction.

\section{Kentucky Bluegrass}

In the Carrington silty clay loam, the root system of Poa pratensis was only 22 inches deep. The bulk of the roots was confined to the shallow A horizon, 7 inches in thickness. Although roots were still abundant in the 3 -inch transitional $B_{1}$ horizon, at greater depths they became noticeably less dense (Fig. 2). In the upper 3 inches of soil many of the

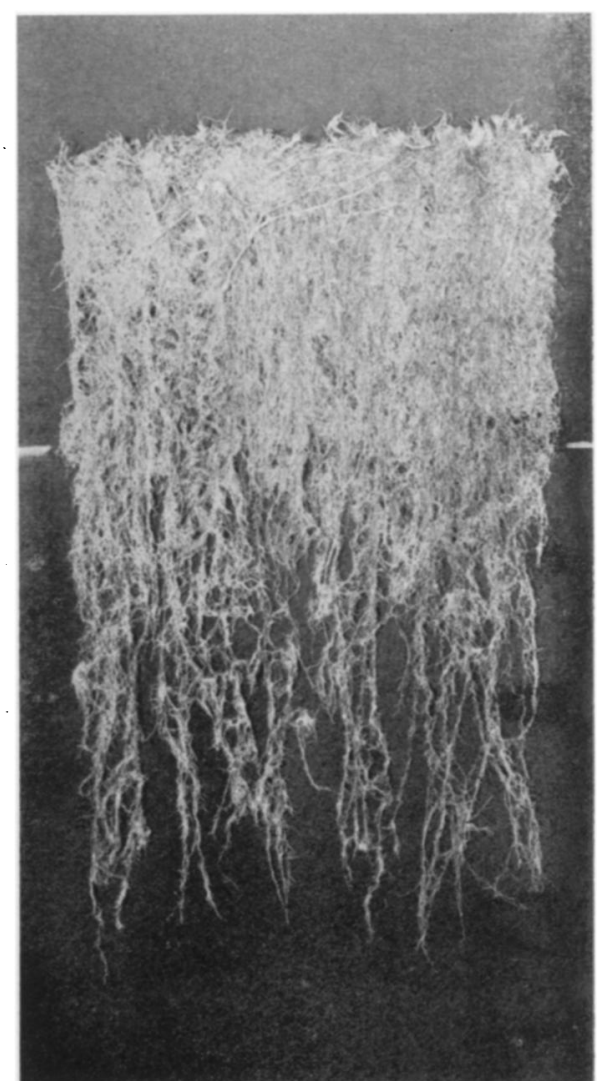

FIG. 2. Root system of Kentucky bluegrass (Poa pratensis) in Carrington silty clay loam. About 82 percent of the weight of roots was found in the upper 7 inches. The lines indicate this 7-inch depth of the A horizon. No roots penetrated into the $\mathrm{C}$ horizon which lay below the 22-inch level.

main roots spread laterally, or somewhat diagonally downward, and with the vertical ones they formed a felted mat. At greater depths most of the roots extended nearly vertically downward. A part of the shallowness of this root system may have been due to grazing and reduced vigor (Weaver \& Darland 1947 ) but undoubtedly the type of soil was a major factor.

Roots of bluegrass in the Wabash silty clay loam penetrated much deeper, some to 3 feet. The massive portion of the root system was slightly less dense, but it extended more deeply. Ninety-two percent of the roots' weight was in the A horizon which occupied the upper 13 inches of soil. Nearly all of the roots pursued an almost vertically downward course from their place of origin, quite in contrast to those in Carrington silty clay loam. There the lateral branches were far more numerous, usually longer, and much more branched than those in figure 3 .

Roots of bluegrass in the deep Judson silt loan were better developed than either of the preceding. The deep A horizon (0 to 20 inches) was well filled with a great mass of roots. But here, as in the preceding samples, they became much sparser in the B horizon. Some extremely well branched roots extended 


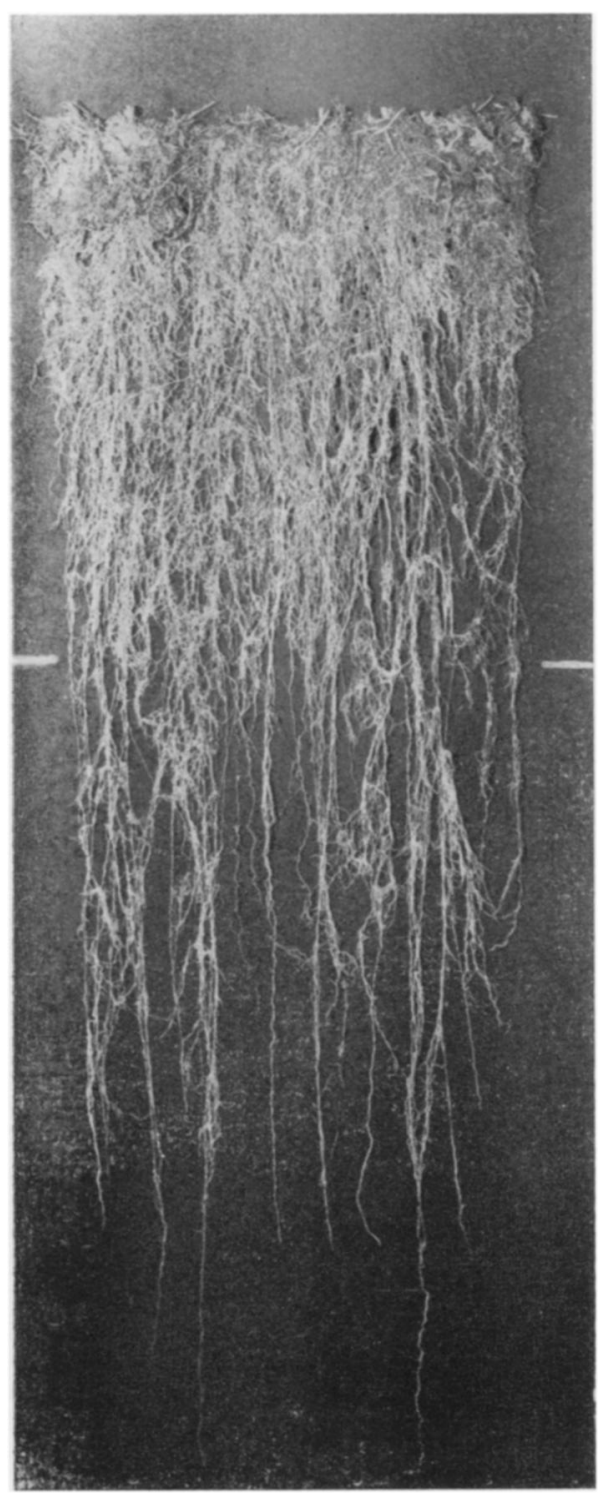

FIG. 3. Root system of Kentucky bluegrass in Wabash silty clay loam. The A horizon (above the lines at 13 inches depth) contains 92 percent of the roots by weight. The deepest roots ended in the B horizon (13-36 in.).

to 4 feet and ended deep in the B horizon (Fig. 4). While total oven-dry weight of the first two root systems was nearly the same, weight of the third was more than three times as great.

\section{Blue Grama}

Roots of Bouteloua gracilis were taken in a monolith from the same trench in Carrington silty clay loam as that used in obtaining Poa pratensis. A photograph of the monolith was taken when about half of the soil had been removed and many of the roots were exposed (Fig. 5). Even casual examina. tion shows clearly that the bulk of the roots are in the surface soil; actually 89 percent occurred in the 7-inch A horizon. Here they formed a dense mat of

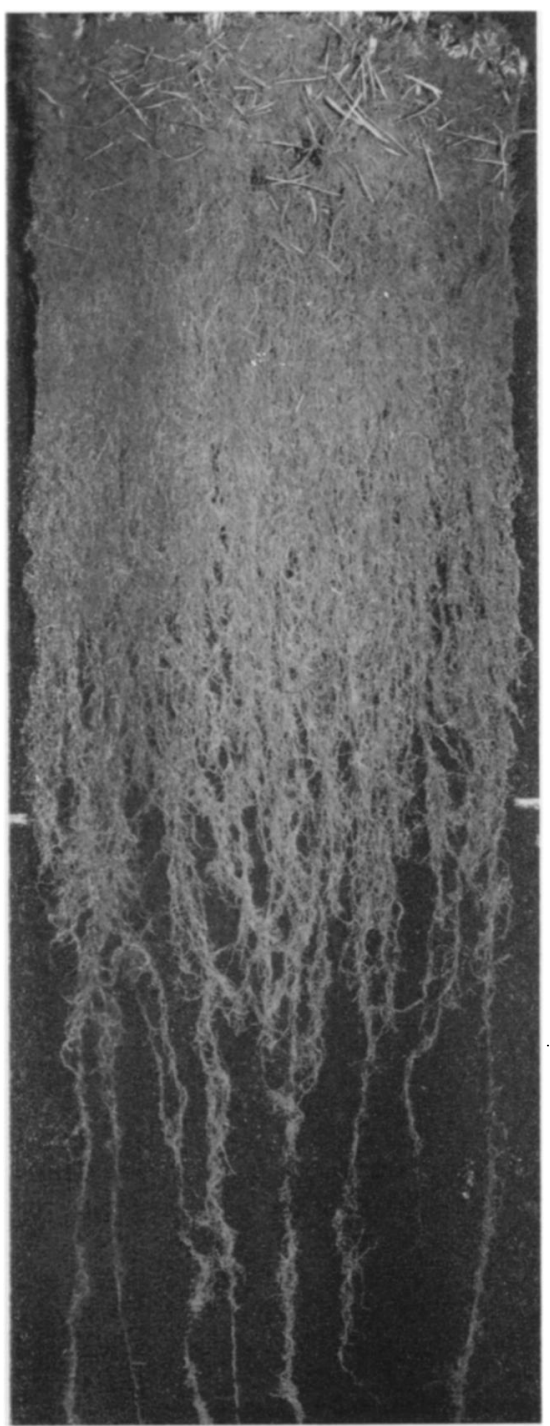

FIG. 4. Rhizomes and roots of Kentucky bluegrass in a deep, moist, but well drained Judson silt loam. The lines at 20 inches depth indicate the top of the $B$ horizon in which the number of roots greatly decreased. Total root depth was 48 inches.

crisscrossing threads. Rocts were fairly numerous in the upper part of the B horizon. Only a few reached a depth of 3 feet where they ended in the pavementlike compacted rebbles and soil.

No blue grama grew in the sccond site, but numerous well developed patchcs occurred in the Judson silt loam. Here they had become established during the great drought (Weaver \& Hansen 1941). The patches alternated with thcse of big bluestem and Kentucky bluegrass. The grass had flourished during a postdrought period of several years. Here again, the massive portion of the rcot systcm occurred in the deep A horizon (above 20 inches), although the transitional $B_{1}$ horizon (20-31 in.) was also fairly well occupied (Fig. 6). This root system was more than three times heavier than the preeeding. 


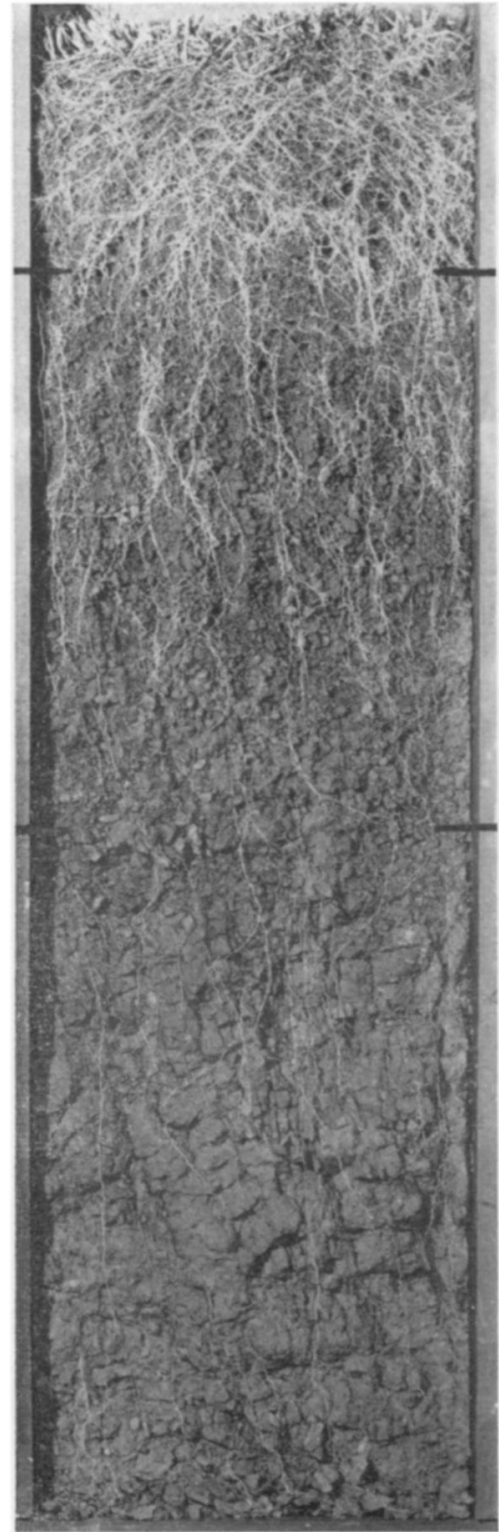

Fig. 5. A three-foot monolith of Carrington silty clay loam from which enough soil has bcen removed to reveal the roots of blue grama (Bouteloua gracilis). There is a close correlation, as in Kentucky bluegrass, between root distribution and the shallow A horizon.

\section{Big Bluestem}

The monolith of Andropogon furcatus was taken only about 50 feet distant from the trench on the level hilltop where the cther grasses were excavated in Carringten silty clay loam. The soil was more moist than in the preceding site, in part because of a better cover of mulch and vegetation, but also because of more rapid water infiltration under big bluestem than under most other species (Weaver 1942; Weaver \& Albertson 1943). Since this species is usually more deeply rooted also, it was not surprising to find a good distribution of roots in the third foot of

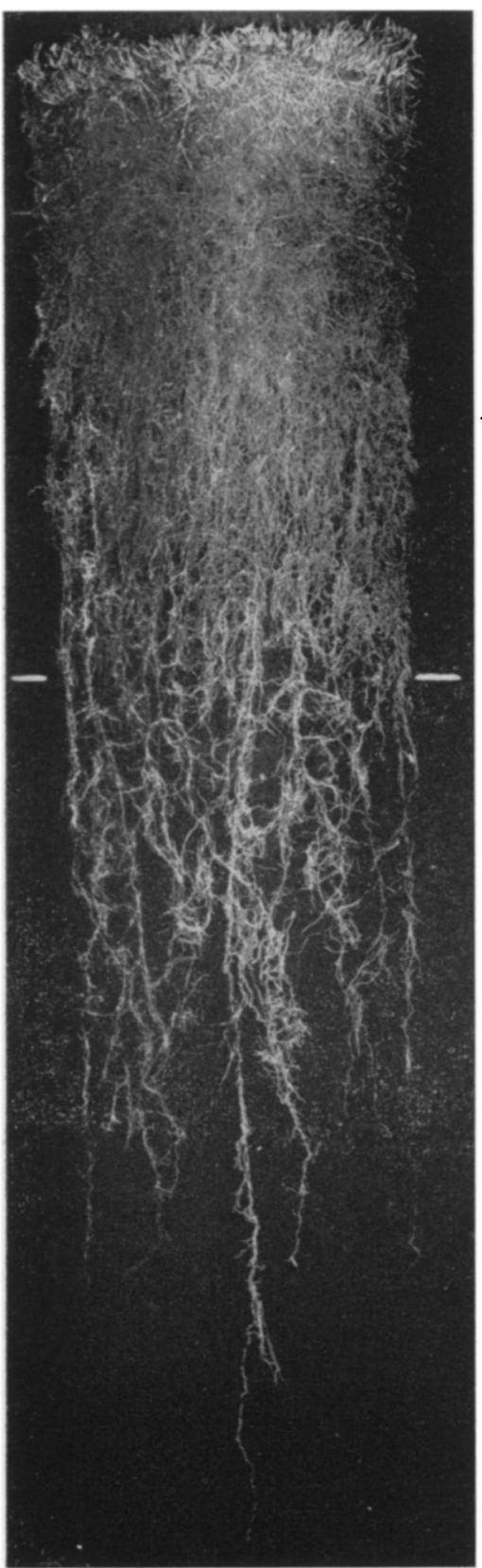

Fig. 6. Roots of blue grama from a 4-foot monolith of Judson silt loam. About 97 pereent of the roots were in the upper 20 inches (A horizon, indicated by lines). Only one or two roots reached a depth of 4 feet.

soil. A few cxtended even deeper. That the bulk of the underground parts is confined to the upper 7 inch:s of soil (A horizon) may be seen in figure 7 . Two striking characteristies were the fineness of the main roots and the high degree of branching.

In the Wabash silty clay loam of the lowland : great mass of roots occupied the A horizon. This lay between 0 and 13 inches depth in this trench, which was a few yards distant from the one in which Kentucky bluegrass was obtained. Roots were fewer in 


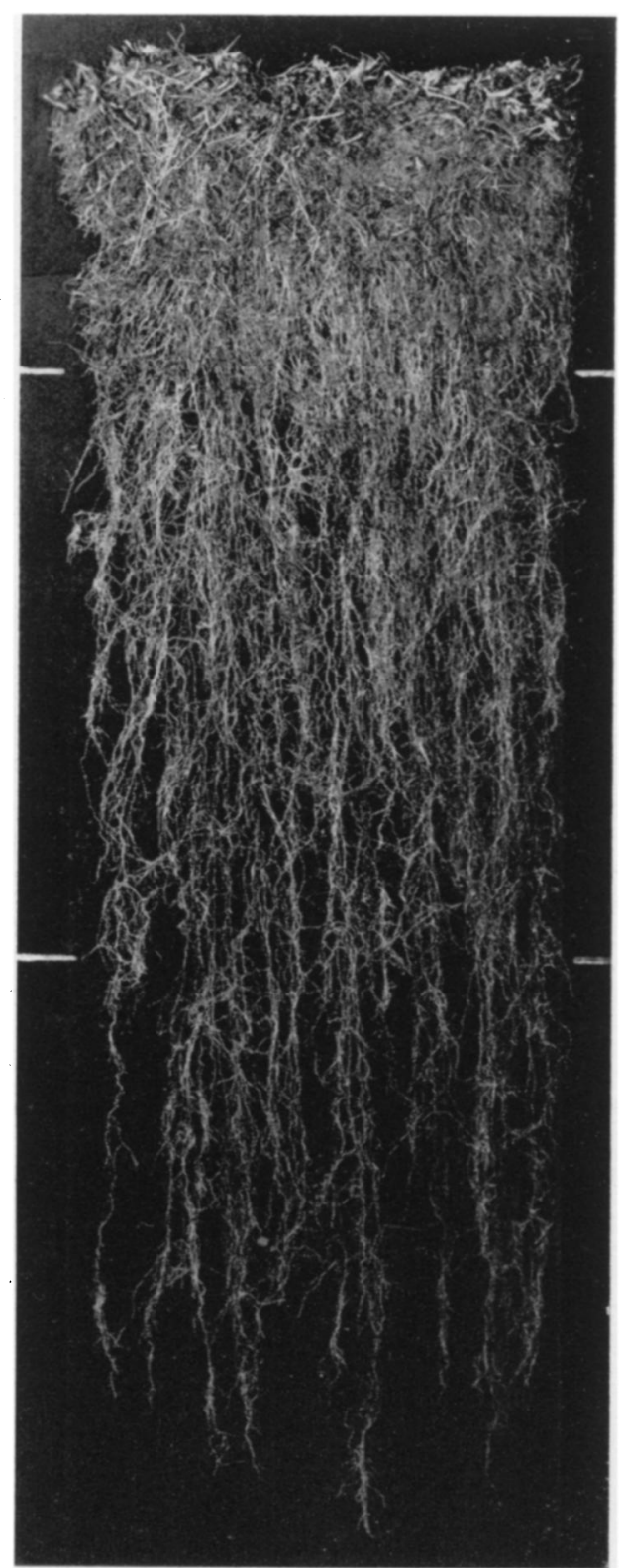

Fig. 7. Roots of big bluestem (Andropogon furcatus) from a 3-foot monolith of Carrington silty clay loam. Decrease in the root mass below the A horizon (0-7 in.) seems less marked than in Kentucky bluegrass and blue grama. Actually 78 percent of the root-weight is in the A horizon and only 18 percent in the B (7-22 in.).

the B horizon. Below 26 inches, where vertical cleavage occurred, the main roots followed the cracks downward, often to a depth greater than 3 feet. During washing, after the soil became very wet, the nutlike blocks ( 1 to 0.25 inch in the long axis) were easily separated. The branch roots were found almost entirely between these and only a few of the smallest roots ended in them.

Chief differences between the two samples were a denser mat of roots in the A horizon in the Carrington

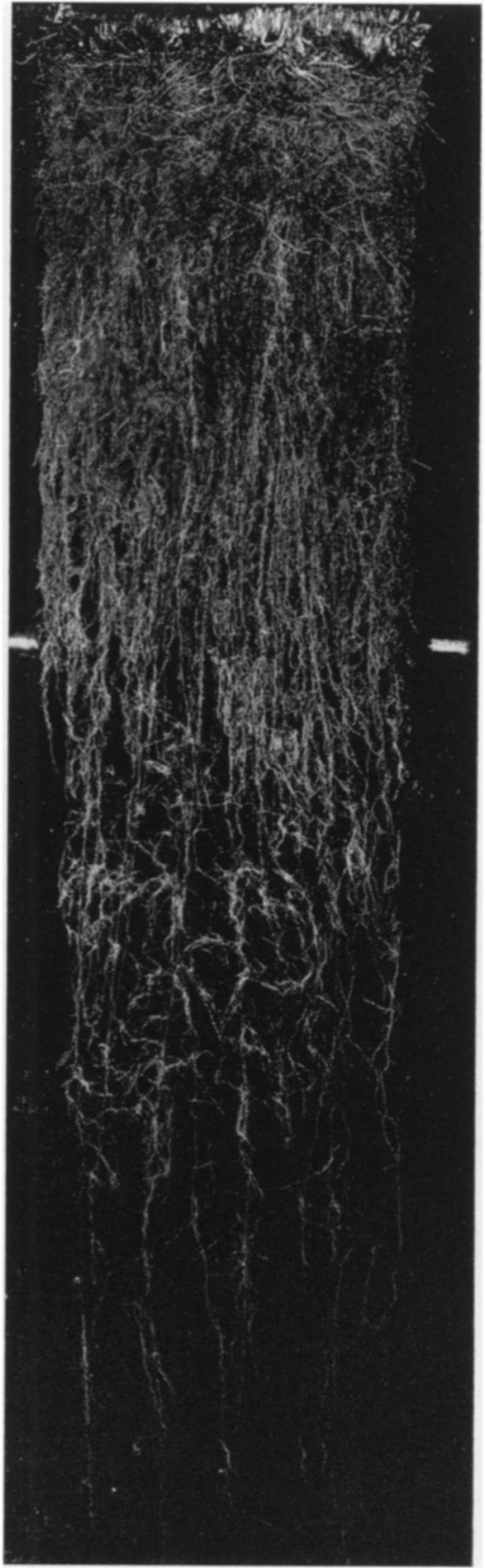

FIg. 8. About 4 feet of the roots of big bluestem in a 5 -foot monolith of Judson silt loam. Note the dense mat of roots in the upper 20 inches or A horizon above the horizontal lines. This mat diminished slowly in the deeper soil. Some roots penetrated beyond a depth of 5 feet.

silty clay loam than in Wabash silty clay loam. Many of the main roots were only $0.25 \mathrm{~mm}$. in diameter in the Carrington but $0.5 \mathrm{~mm}$. in the Wabash soil. Similar differences were found when the largest main roots were compared. The greater degree of branching of the roots in the Carrington soil was equally as pronounced as in Kentucky bluegrass. Although 
these differences were very marked, especially the greater penetration of the mass of roots to more than twice the depth in Wabash soil than in Carrington, yet the total dry weight was nearly the same in both sites.

The root system of big bluestem from the Judson silt loam, and from the same trench as the bluegrass, was far better developed than either of the preceding samples. The A horizon here was 20 inches deep. It contained an immense mass of heavy, thick roots (Fig. 8). This alone weighed approximately twice that of the entire root system of either of the other plants. As usual at greater depths, the number of roots and the amount of root materials decreased rapidly. But some main roots extended to 5 feet in this very deep, fertile, but moderately moist soil.

\section{ROOT DISTRIBUTION IN SOILS WITH CLAYPANS}

"One or more groups of soils within each soil zone have peculiar properties that set them apart from soils considered 'normal' for that zone. Usually one or more horizons of each of these zones is overdeveloped and in marked contrast to the normal soil. These are called intrazonal (within-zone) soils. Planosols of the Prairie and Chernozem soil zones, and claypan soils of drier regions are intrazonal soils characterized by grassy vegetation. The most extremely developed of the Planosols have very thin surface horizons of dark-colored material rich in organic matter. Beneath the thin dark horizon is light-colored, friable, platy material several inches thick, with little organic matter, and usually moderately to strongly acid in reaction. Beneath is a strongly developed clayey horizon, or claypan" (Thorp 1948).

\section{Western Wheat Grass in (5) Crete Silty Clay Loam}

The first monolith from soil with a claypan was taken from a hillside in Crete silty clay loam. It was located on a midslope in a pasture adjoining the experimental prairie 3.5 miles northwest of the University of Nebraska. The pasture had been lightly grazed for several years and the western wheat grass (Agropyron smithii) presented an excellent, uniform stand about 18 inches high and free from other vegetation. This species had been in complete possession of the site since about 1937.

The roots had three very different habitats. The first consisted of 12 inches of a black, well granulated silty clay loam which composed the A horizon. This included nearly two inches of topsoil blown from an upland field during the drought. It was finely granulated and slightly platy in structure. The soil beneath was mellow and composed of small granules mostly 1 to $4 \mathrm{~mm}$. in diameter. The granules became larger with depth and at 10 inches they ranged in diameter from 1 to $8 \mathrm{~mm}$. The $\mathrm{pH}$ was 6.8 .

At 12 inches depth there was a very distinct and abrupt transition to a blocky prismatic structure with a $\mathrm{pH}$ of 6.6. The clay content increased rapidly with depth and the soil was extremely hard when dry.

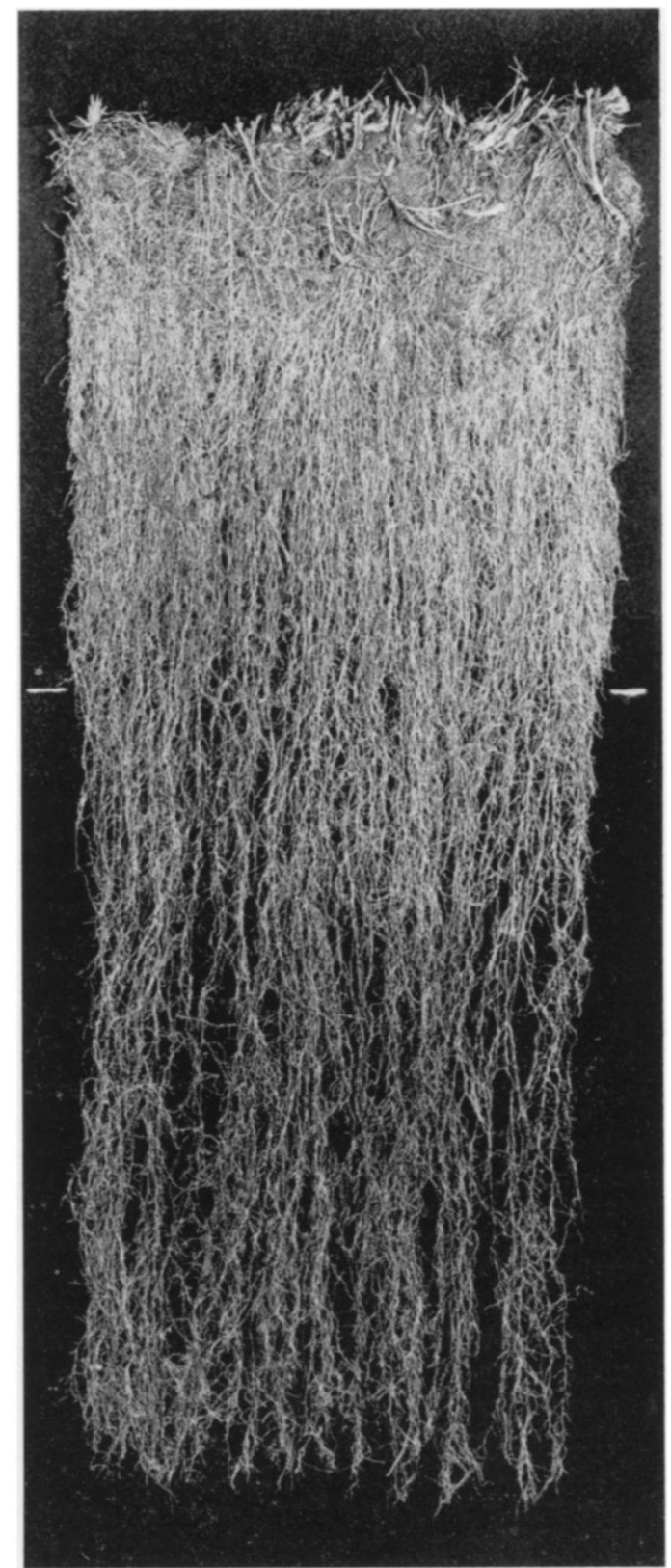

Fig. 9. Root system of western wheat grass (Agropyron smithii) in the $\mathrm{A}$ and $\mathrm{B}$ horizons from the upper 28 inches of a 4-foot monolith from Crete silty clay loam. Note the thinning of the root-mat at about 12 inches depth (horizontal lines) where it enters the B horizon. The dry weight of roots in the B horizon is less than a third of that in the layer above.

Vertical prisms varied in diameter from 3 to 4 inches; they were often 5- or 6-sided, and 8 to 12 inches long. They were sometimes broken by more or less horizontal cracks. In excavating the trench this clayey layer was removed only after much labor.

At a depth of 28 inches, the dark brown subsoil gave way to the $C$ horizon of yellowish loess which is a silty clay loam with massive structure. It had a 


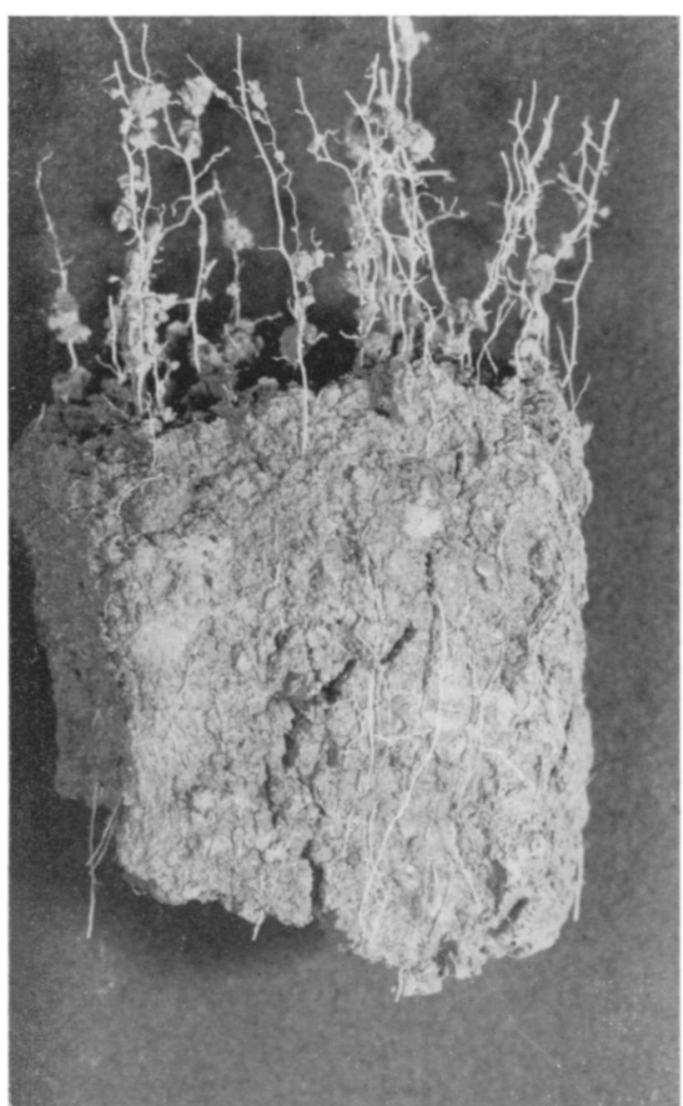

Fig. 10. Portion of a soil prism, about 3 inches in width, from the upper part of the B horizon. Its high clay content results in its being very compact when water content is low. Note the granules of soil clinging to the roots in the A horizon. The roots stretch considerably before breaking when the soil shrinks and cracks during dry weather.

much smaller content of clay. This, with the presence of abundant lime, often in small concretions, made digging much less difficult. The $\mathrm{pH}$ was 7.5. The soil broke up into blocky pieces to a depth of more than 4 feet.

In separating the roots from the soil it was observed that the rhizomes were confined mostly to the first two inches of topsoil. From thcm and from the base of the plants the tough roots, usually a millimeter or less in diameter, penetrated mostly vertically downward. They occurred in large numbers. There were about 515 at a depth of 2 inches in the 36-square-inch cross-section of the monolith. In the mellow soil of the A hor:zon (0-12 in.) the roots wcre found in great masses. They were distinctly fewer in the $\mathrm{B}$ horizon (12-28 in.). Only about 165 main roots entered this layer and the number decreased to 85 at two feet in depth (Figs. 9 and 10). Branching of the main roots was much less pronounced in the $B$ than in the $A$ horizon. While the roots penetrated this compact soil vertically through the columns (probably when they were quite moist), they were also common in the

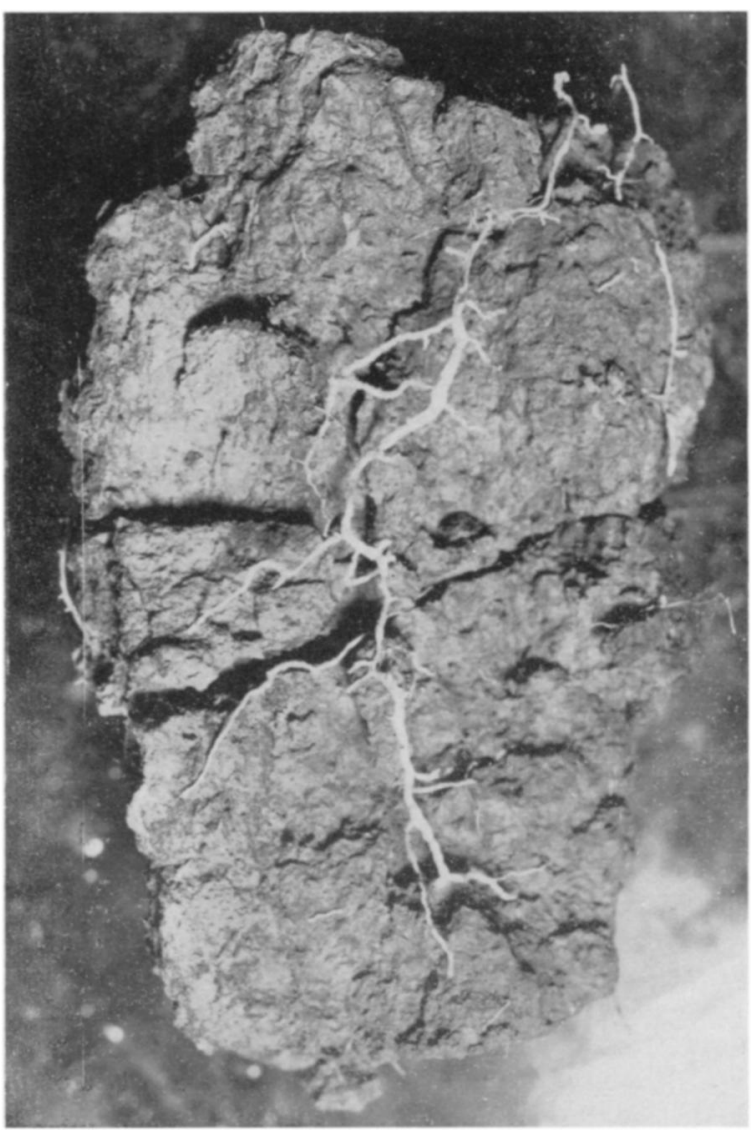

Fig. 11. Portion of a prism of soil about natural size from the lower third of the B horizon. Note the blocky structure. Many main roots grew downward on the surfaces of the prisms and were attached to the soil only by their finer branches.

crevices between them. Here they branched abundantly but mostly in a single plane (Fig. 11). Bundles of 3 or more living roots were often found following previous root channels.

In the mellow, moist, loessal parent material of the $C$ horizon there was a type of root distribution distinctly different from that in the $\mathrm{A}$ and $\mathrm{B}$ horizons. The roots were often flattened on the faces of the small blocks which cleaved in all directions (Fig. 12). Thus, branching occurred in all planes. Although roots were more abundant on the outside of the cloddy masses, many were penetrated by some roots. When this moist, soft loess was washed from the roots, there remained a glistening white mass of material with branches running out at all angles (Fig. 13). Thus, the rooting habits in the three soil horizons were as different as the environment each presented. Some main roots penetrated to greater depths than 48 inches. The weight of the roots in the $B$ horizon (12-28 in.) was only slightly greater than that part of the root system in the portion of the $\mathrm{C}$ horizon (28-48 in.) contained in the monolith. 


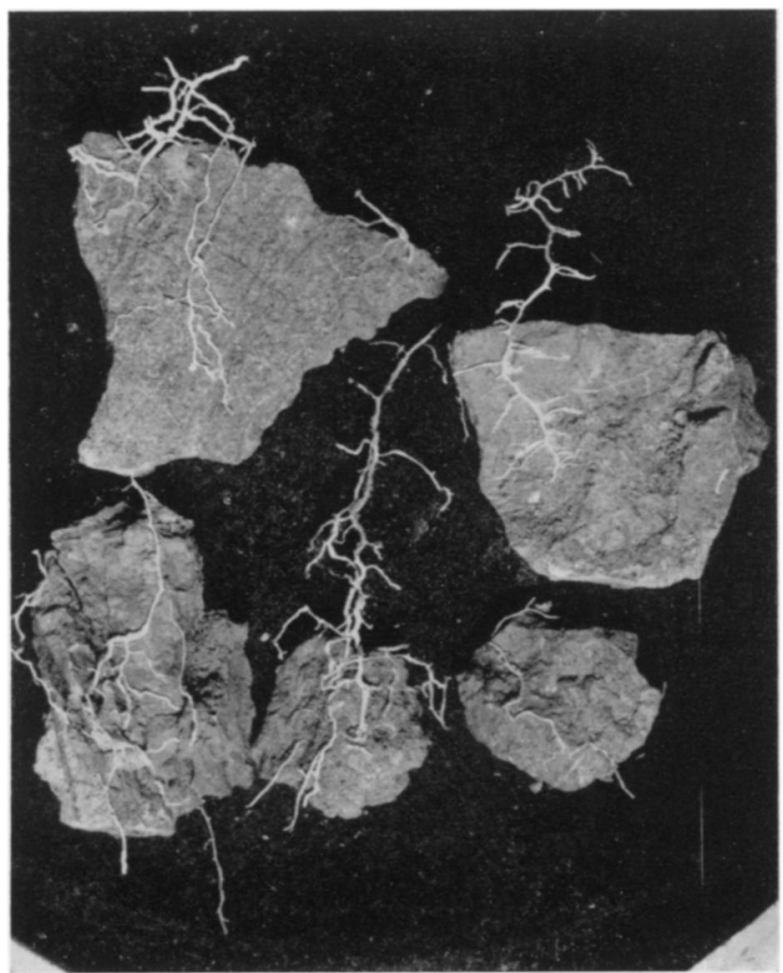

FIG. 12. Details of root patterns about natural size in the $\mathrm{C}$ horizon showing root branching and flattened roots on the platy lumps. Many roots scarcely entered the soil but were compressed and flattened between the lumps of parent material. Portions of roots 2 or more inches long but unattached to the soil were quite abundant.

\section{W estern Wheat Grass in (6) Butler Silt Loam}

A second monolith was taken from a claypan soil (Planosol) near Carleton, Nebraska, 65 miles southwest of Lincoln. Here the mean annual precipitation is an inch less (26.9) than that at Lincoln. The sample was from a small area of Butler silt loam, the surrounding soil type on this nearly level land being Crete silt loam. The area examined was formerly covered with bluestem grasses. But thcse were entirely replaced during the drought by a good stand of western wheat grass (Weaver 1943).

\section{BUTLER SILT LOAM, THIN SURFACE-SOIL FHASE}

This soil has a thinner A horizon than is typical of the Butler soils, and the $A_{2}$ ( 6 to 7.5 inches) has a little more clay than is typical for this horizon. The $\mathrm{A}_{2}$ has an indistinct, leached, gray sprinkling of silt on the exterior of the structure particles showing a tendency toward degradation and leaching as in the $A_{2}$ horizon of more typical Butler soils.

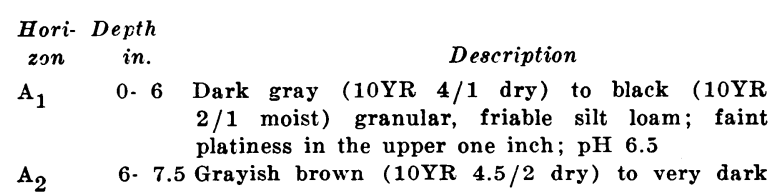

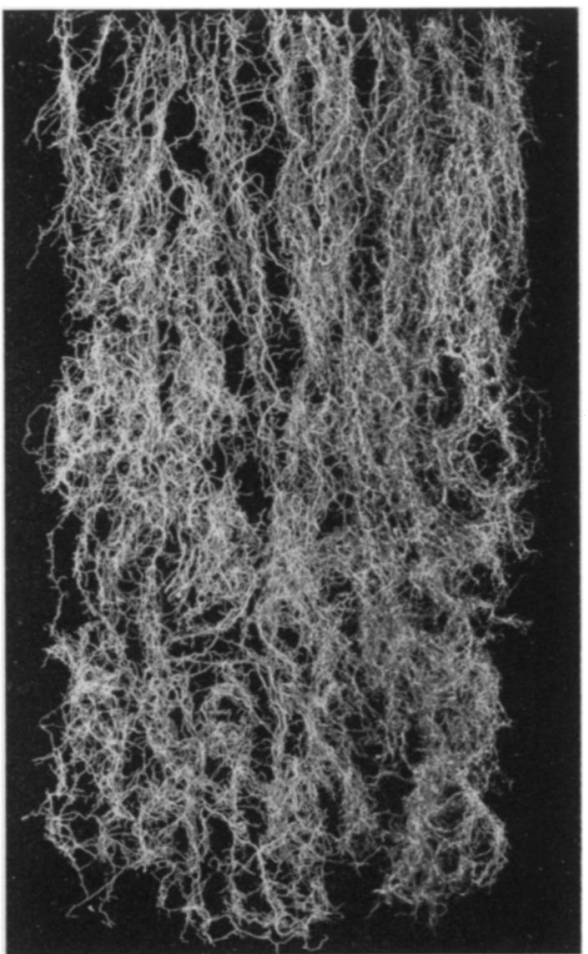

Fig. 13. Main roots of western wheat grass (about 45 in number) and their branches from the upper 20 inches (28 to 48 in. depth) of the $\mathrm{C}$ horizon of (5) Crete silty clay loam. This is a portion of the root system shown in figure 9 .

brown (10YR $2 / 2$ moist) coarse granular, friable silty clay loam; contains a faint sprinkling of gray, leached silt on the structure particles; pH 6.5

$B_{2-1}$ 7.5-18 Dark grayish brown (10YR 4/2 dry) to very dark grayish brown (10YR $2 / 3$ moist) blocky clay; hard when dry; $\mathrm{pH} 7.0$

$B_{2-2} 18.22$ Olive brown $(2.5 Y \quad 4 / 4$ dry $)$ to dark grayish brown (10YR 4/2 moist) light clay; blocky; moderately hard when dry; $\mathrm{pH} 7.5$

$B_{2-3} 22-25$ Light olive brown $(2.5 \mathrm{Y} 5 / 4 \mathrm{dry})$ to brown (10YR $5 / 3$ moist) blocky silty clay; moderately friable; contains an occasional small lime concretion, otherwise not calcarcous; $\mathrm{pH} 7.7$

$\mathrm{B}_{3} \quad 25.28$ Yellowish brown (10YR 5.5/4 dry) to dark yellowish brown (10YR 4.5/4 moist) silty clay or light silty clay; medium blocky; moderately friable; scattering of lime ccncretions; $\mathrm{pH} 7.8$

$\mathrm{C}_{1} \quad 28.36$ Light yellowish brown (10YR 6.5/4 dry) to yellowish brown (10YR $5.5 / 4$ moist) friable silty clay loam; ill-defined blocky structure; concretionary and disseminated lime; $\mathrm{pH} \mathbf{7 . 8}$

The $\mathrm{A}_{1}$ and $\mathrm{A}_{2}$ horizons are moderately plastic, and the remaining horizons are very plastic and sticky when wet.

The monolith was taken in a good stand of western wheat grass only 50 feet from a trench in the big bluestem-little bluestem relict type where two others were obtained. Recent rains had wet the Butler silt loam to a depth of 5 to 6 inches, or nearly through the 7.5-inch A horizon. Exceptions occurred where water entered the large soil cracks and penetrated 


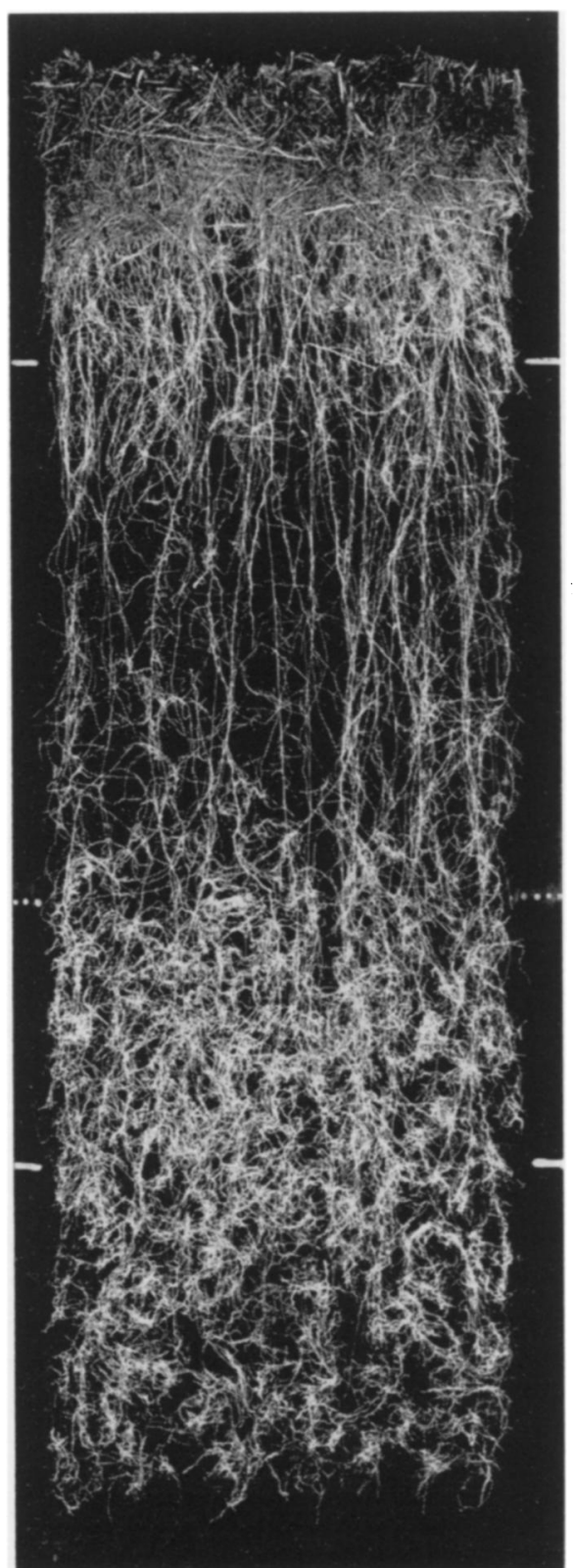

Fig. 14. Root system of western wheat grass from a 3-foot monolith of claypan soil, (6) Butler silt loam, near Carleton, Nebraska, showing the profound differences in the root habit in the three soil horizons. There are far fewer roots in the shallow A horizon (above upper lines) than is normal in mellower soils. Branching in the $B$ horizon (above lower lines) is poor except in the lower third. But, as in the preceding sample, it is pronounced in the mellow, moist soil of the $\mathrm{C}$ horizon. Dots indicate a depth of 20.5 inches.

deeply, in one place to 29 inches. The entire B horizon (7.5-28 in.) was so hard that the soil was removed only with extreme difficulty. The soil was cracked to a depth of about 22 inches. These cracks below 8 in. depth, were as wide as $3 / 8$ inch. The $\mathrm{B}$ horizon broke out in large blocks because of the wide, nearly verti- cal cracks. A pick was constantly employed. The roots penetrated the $\mathrm{B}$ horizon with difficulty and probably (except in cracks) only when the soil was moist. They were nearly always more or less flattened and in the upper half of the horizon more poorly branched than in either the $\mathrm{A}$ or $\mathrm{C}$ horizon (Fig. 14).

At 28 inches depth, the yellowish, less compact, lime-flecked parent material of the $\mathrm{C}$ horizon was encountered. Here, as in the lower third of the $B$ horizon, branching of roots was pronounced; many of the branches were short, flattened, and greatly enlarged. They penetrated the soil in all directions and produced a dense network.

The heavy branching began near the bottom third of the $B$ horizon at 20.5 inches in depth. The weight of the roots in the 13 inches above this depth in the B horizon (7.5 to 20.5 inches) was actually less than that in the 13 inches below this level (20.5 to 33.5 inches). The increase in weight at the greater depth was 36.5 percent. There were only a few roots that penetrated beyond 36 inches.

Aside from the surface 6 inches, the root system was very much lighter than that of the preceding sample, except in the third foot where the oven-dry weights were approximately the same (Figs. 9, 13, and 14).

Root Development in Adjacent Soil

Quite in contrast was the root development of both big bluestem and little bluestem in a heavy (7) Crete silt loam soil only 50 feet distant where wheat grass had not invaded. Here the elevation was slightly less than that of the surrounding Butler soil. The A horizon was 11 inches thick and the $B$ horizon extended to 3 feet.

\section{CRETE SILT IOAM, THICK SOLUM}

The several horizons and subhorizons of this soil are thicker than common for the general run of Crete soils, and no free carbonate of lime occurs in the soil to the depth sampled. ${ }^{1}$ The texture, structure, and consistence of the various horizons are about typical of Crete soils; they are gradational from one to the other. Horizons described as friable in the dry and slightly moist state are plastic and sticky when wet.

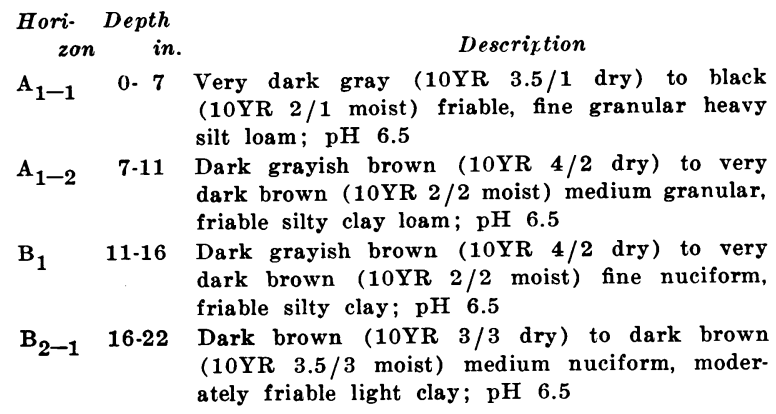

1 The sample is from an area where the parent loess is low in lime. J. C. Maker, Isomarmor. Map of the Peorian loess in Nebraska, 1935-1936 (unpublished). 


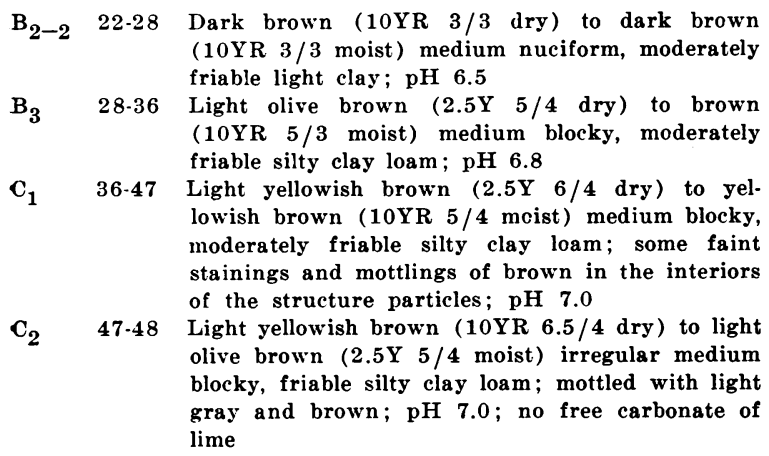

This black granular soil had been uniformly wet by recent rains to a depth of 9.5 inches. In fact, the soil was moist at all depths to 5 feet. No cracking was observed. It was a heavy type of soil, yet the roots of the grasses extended nearly to or somewhat beyond the 4-foot depth of the monoliths (Figs. 15 and 16). The roots were extremely well developed. They were consistently of greater weight in each foot of soil than those in (4) Judson soil at Lincoln, although the growth of tops was somewhat less.

It is important to note that the horizons of Crete soils are more gradational with one another than are those of the planosolic Butler soils, and that the Crete has no A2 horizon above the heavy but well-structured $\mathrm{B}$ horizon.

The (6) Butler silt loam prevailed to the edge of the (7) Crete silt loam with the bluestem grasses. The relict grasses were bounded on three sides by wheat grass or wheat grass and buffalo grass growing in the Butler silt loam. On the remaining side there was cultivated land. By probing with a soil tube, the very compact $B$ horizon was found to occur at 6.5 to 8.5 inches depth in all places surrounding the bluestem prairie. The transition from one soil type to the other was clearly indicated by the change from bluestems to wheat grass; the ecotone where these grasses were mixed was only a yard or two in width. Further examination revealed that the Butler soil formed a rim several rods wide about the patch of bluestems but farther outward gave way to Crete silt loam which was also clothed with western wheat grass. The soil under bluestems probably receives more water than the surrounding area, but the water does not stand long enough to cause a true claypan. This rim of Planosol (true claypan) about it on three sides is not an unusual phenomenon.

\section{Western Wheat Grass in (8) Scott Silty Clay Loam}

There is a large area of Scott soil in a depression about a mile wide, probably an old lagoon, 2.5 miles west of Bruning, which is near Carleton, Nebraska. It is covered largely with native vegetation, much of which is western wheat grass. The wheat grass was of only moderate density and height.

\section{SCOTT SILTY CLAY LOAM}

This sample is a variant of the Scott soils that lacks the well-developed light gray $A_{2}$ horizon. In many

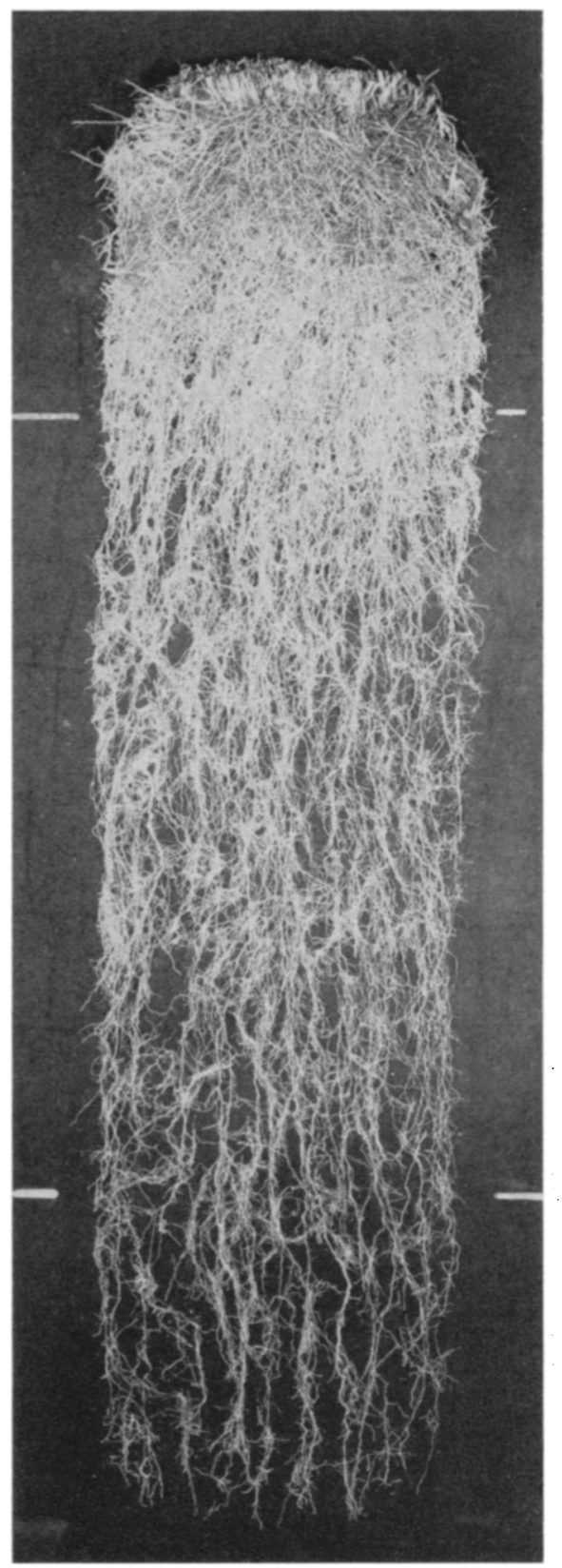

Fig. 15. A very heavy root system of little bluestem from a 4-foot monolith taken only 50 feet from that in figure 14. There is a uniform decrease of roots with depth in this (7) Crete silt loam with a thick solum, although 85 percent of the root-weight is in the A horizon. The longest roots attained a depth of 46 inches.

places free lime carbonate is leached to greater depths in Scott soils.

$$
\begin{aligned}
& \text { Hori- Depth } \\
& \text { zon in. Description } \\
& A_{1} \text { 0- } 5 \text { Dark gray (10YR 4.5/1 dry) to very dark gray }
\end{aligned}
$$


when dry to form large irregular columns; irregular horizental breakage of columns forms large irregular blocks. The lower part of this horizon is gradational in color and texture to the third (C) horizon. A sprinkling of soft iron or manganese concretions ( 1 to $5 \mathrm{~mm}$. in diameter) occurs throughout this horizon; $\mathrm{pH} 6.5$

C 41.48 Light gray (10YR $7 / 2$ dry) to light brownish gray (10YR 6/2 moist) massive silty clay; contains a sprinkling of lime concretion, otherwise not calcareous; $\mathrm{pH} \mathbf{7 . 5}$

All horizons are plastic and sticky when wet.

The top soil, including 2 inches of dust deposit, is only 5 to 6 inches thick. Below this l'es the claypan of the B horizon. It was impossible to remove this layer until a crack was found that had let the water from recent rains infiltrate and thus soften the soil. The tiling spade could not be forced into the soil except by striking the top of the blade repeatedly with a sledge hammer. Many strokes of the hammer were required to sink the spade even a few inches in depth. Numerous cracks were observed in the trench wall, some were a half-inch in width. They resulted from the shrinking of the clay into large blocks and columns, some of which were a foot or more thick. The soil was so compact and heavy that it required seven hours of very hard work by three experienced men, who would have dug a similar trench in ordinary soil in two hours. The roots penetrated the prisms and blocks of soil throughout probably at a time when they were wet or at least very moist. This is quite in contrast to the behavior of the bluestems which in hard soils (but not so compact as this) often leave lumps and clods unpenetrated. Many if indeed not most of the roots were flattened and thickened. The branches were often short. Other roots were of normal circular area in cross-section. The soil seemed to be well threaded by them but no other data could be obtained in digging except as to their presence or absence and abundance. It was difficult to crush the lumps even with a sledge hammer.

In the dark gray, thick B horizon (5-41 in.) the soil was much compacted. It became slightly less difficult to remove at a depth of 35 inches. Lime concretions appeared in the $C$ horizon at a depth of 45 inches. But even here the soil was firmly compacted. In the 4-foot monolith taken between two large cracks, the roots did not extend below 31 inches.

After a long period of soaking and intervals of washing, the root system was secured in its entirety (Fig. 17). In fact, contrary to the expectations of the authors and the soil examiners, when the soil became thoroughly wet and swollen it washed away from the roots quite readily. The primary components were particles of small size. Root branching was especially poor in the upper portion of the claypan. It increased somewhat with depth. It was very pronounced below 20 inches, that is, in the lower half of the second and upper half of the third foot.

Roots in the cracks on each side of the monolith penetrated to a maximum depth of 40 inches. "Dry weather so shrinks and cracks many of the claypans that water penetrates them readily following dry

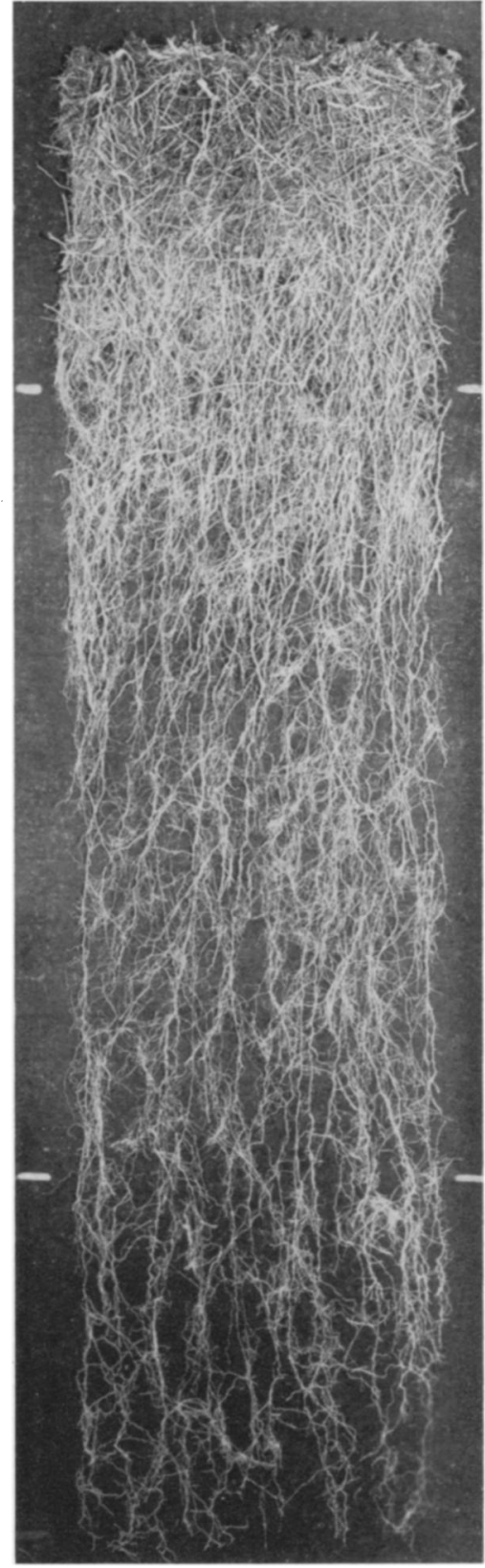

Fig. 16. Roots of big bluestem taken from the same trench as the little bluestem. The roots are most abundant in the A (0-11 in.) horizon despite the fact that the $B$ horizon (11-36 in.) is 25 inches thick. Total weight of these coarser roots was about the same as those of little bluestem (Fig. 15).

weather. Grass roots work their way between the blocky- and prismatic-structured particles into deeper layers of the subsoil in search of moisture, and some of the roots actually pierce the dense blocks and prisms of clay. Such penetration tends to lessen the undesirable physical conditions of the soil. Shrinking and expanding of the clay blocks with changes in moisture have the effect of flattening the roots, but 


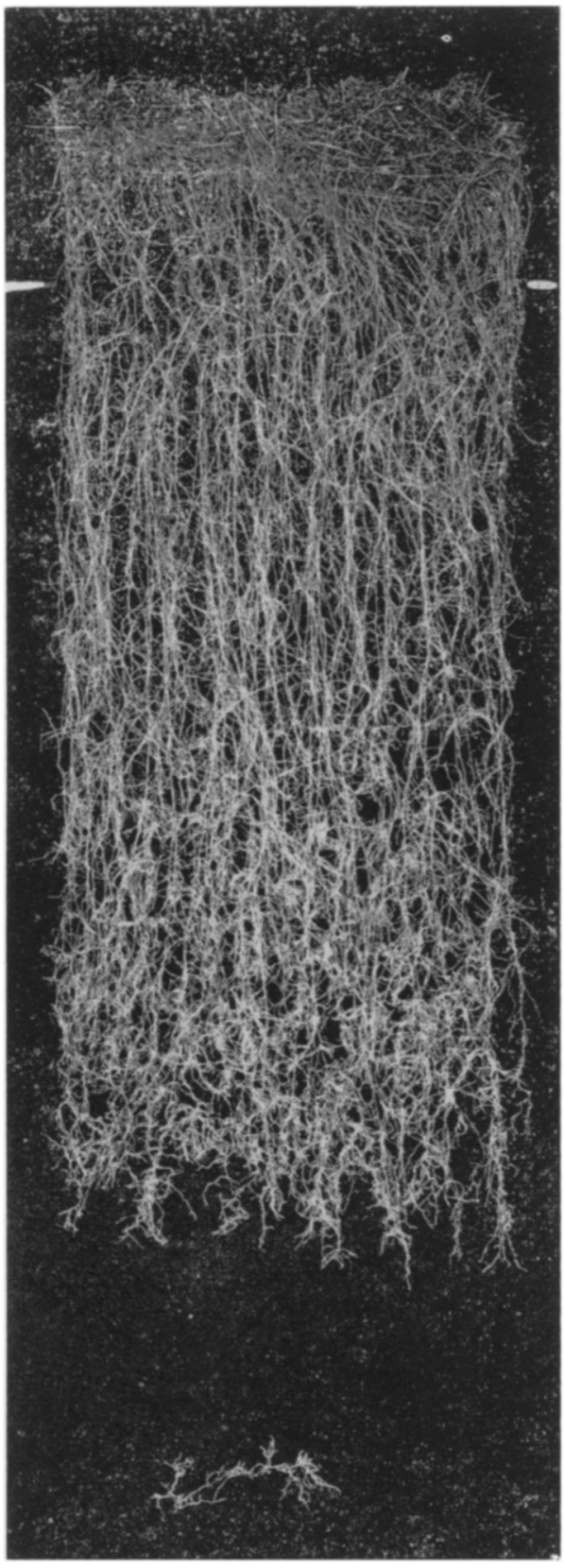

Fig. 17. Root system of western wheat grass washed from a 4-foot monolith of (8) Scott silty clay loam which had a thick elaypan. Roots were not of usual abundance even in the shallow A horizon (0-5 in.). They were sparse and relatively poorly branched in the upper portion of the $\mathrm{B}$ horizon (i.e. 5 to 20 inches depth) but branching increased at greater depths and continued to the root-ends at 31 inches. The isolated root at 37 inches depth is a branch from a root which penetrated deeply in a large crack at the side of the monolith.

this process does not kill them except where extreme shrinkage in dry weather breaks them asunder. Only in soils with subsoil horizons very low in plant nutrients and moisture do the roots fail to penetrate the claypans" (Thorp 1948).
One root entered the monolith at 37 inches depth (Fig. 17). Like the others, it was profusely branched but mostly with relatively short laterals. As in (6) Butler silt loam, the laterals were shorter but heavier than normal. Many were not only flattened but also thickened in all dimensions. The branches ran in all directions, downward, horizontally, or even vertically upward, probably extending into the most penetrable part of the soil mass. Amount of root material was small compared with that from the wheat grass in (5) Crete silty clay loam near Lincoln.

\section{Western Wheat Grass in Rendzina Soil}

Four miles east of Belleville, Kansas, and 45 miles southeast of Carleton, western wheat grass has occupied a well drained lowland, surrounded on three sides by steep slopes, for a long period of time. Before the great drought of 1933 to 1940 this was the only place that wheat grass occurred in this bluestem prairie. It remained as a pure stand during the drought and also during seven years of postdrought, big bluestem being unable to replace it. This soil was presumed to have a claypan.

Upon digging a trench no claypan was found, but the soil had a clayey subsoil in which the blocky and nuciform aggregates were strongly developed and quite stable. Consequently the material was removed from the roots only with extreme difficulty. At 38 inches in depth this heavy soil gave way abruptly to a hard, unweathered limestone which formed a barrier to water penetration in the soil and probably caused it to be very wet and poorly aerated during periods of high rainfall. In this respect it was similar to soil with a claypan, which may explain the absence of the bluestems.

\section{RENDZINA SOIL OF THE CHERNOZEM ZONE; SERIES NAME NOT DETERMINED}

This soil in its morphological aspects is quite typical of Rendzinas of the Chernozem zone. It is developed in local alluvium-colluvium from the surrounding slopes over weathered limestone, plus probably a thin covering of loess. It is mildly calcareous in the upper horizon and strongly calcareous in succeeding horizons. The associated Bloomington soils are normally leached of free carbonates to a depth of one to two feet and are neutral or slightly acid in the surface and upper subsoil layers. The $\mathrm{B}_{1}, \mathrm{~B}_{3}$, and $\mathrm{C}_{1}$ horizones are plastic when wet.

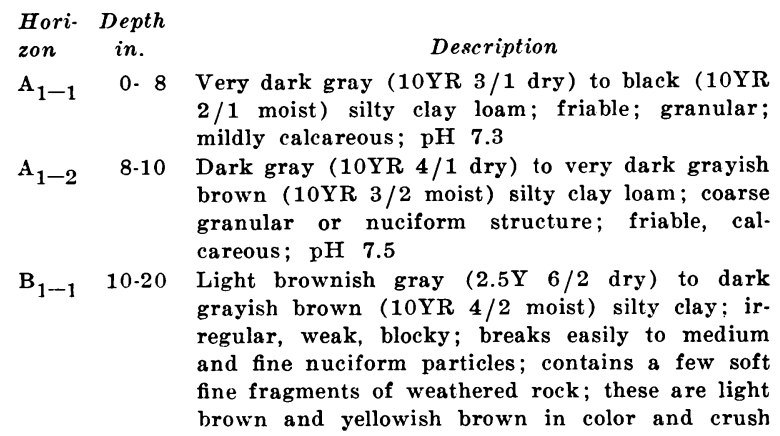
$2 / 1$ moist) silty clay loam; friable; granular; mildly calcareous; $\mathrm{pH} 7.3$

A 1-2 8-10 Dark gray (10YR 4/1 dry) to very dark grayish brown (10YR $3 / 2$ moist) silty clay loam; coarse granular or nuciform structure; friable, calcareous; $\mathrm{pH} \mathbf{7 . 5}$

$B_{1-1} \quad 10-20$ Light brownish gray $(2.5 \mathrm{Y} 6 / 2$ dry $)$ to dark grayish brown (10YR $4 / 2$ moist) silty clay; irregular, weak, blocky; breaks easily to medium and fine nuciform particles; contains a few soft fine fragments of weathered rock; these are light brown and yellowish brown in color and crush 
easily to a powdery very fine sand or silt mass; strongly calcareous; $\mathrm{pH} \mathbf{7 . 5}$

$B_{3} \quad 20.27$ Light gray $(2.5 \mathrm{Y} 7 / 2 \mathrm{dry})$ to light olive brown (2.5Y $3.5 / 4$ moist) silty clay loam; medium blocky; moderately friable; weathered rock frag ments are more numerous than in layer above strongly calcareous; $\mathrm{pH} 7.5$

$\mathrm{C}_{1} \quad$ 27-36 Light gray (10YR 7/3 dry) with yellow mottlings $(2.5 \mathrm{Y} 7 / 6 \mathrm{dry})$ to light brownish gray $(2.5 \mathrm{Y}$ $6 / 2$ moist) with yellow mottlings, silty clay loam friable; shows stratification of alluvial deposition or of weathered stratified bedrock; strata are separated by thin lenses or a sprinkling of fine sand; contains weathered rock fragments as in

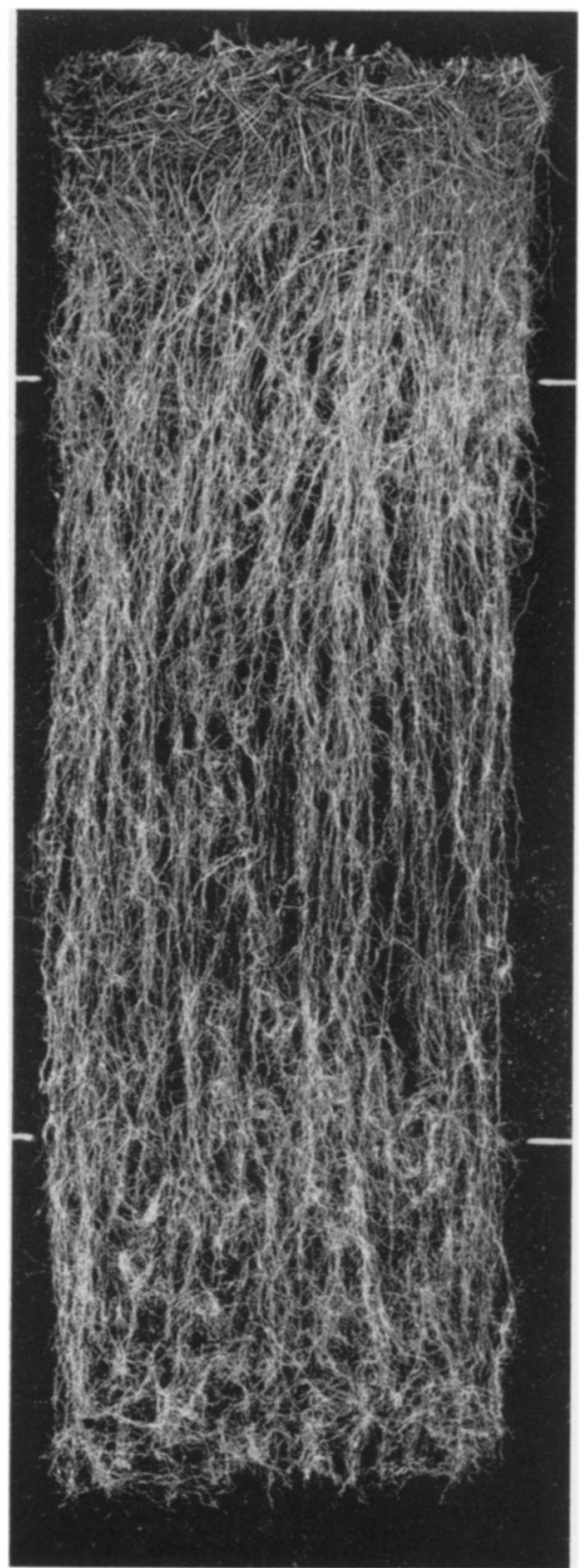

FIG. 18. Three feet of roots of western wheat grass from a monolith of Rendzina soil underlain by unweathered limestone in a ravine. There is no increase in rootweight in the third foot over that of the second, but a great increase in branching. the layer next above; strongly calcareous; $\mathrm{pH}$ 7.5

$\mathrm{C}_{2} \quad 36-38$ This is like the layer next above, except that it contains shell fragments from the weathered limestone

D $\quad 38 \quad$ Limestone bedrock

The general appearance of the root system, which branched profusely in the bottom of the $B$ horizon and especially in the $\mathrm{C}$ horizon (27-38 in.), was similar to the preceding (Fig. 18). There was a distinct thinning of the root mass in the $B$ horizon and a great increase in branching in the $\mathrm{C}$ layer. Here the roots often occurred in small bundles or groups of 5 to 13 . A mat of roots 2 to $3 \mathrm{~mm}$. thick was lifted from the rock in places while many roots were firmly attached to it elsewhere (Fig. 19).

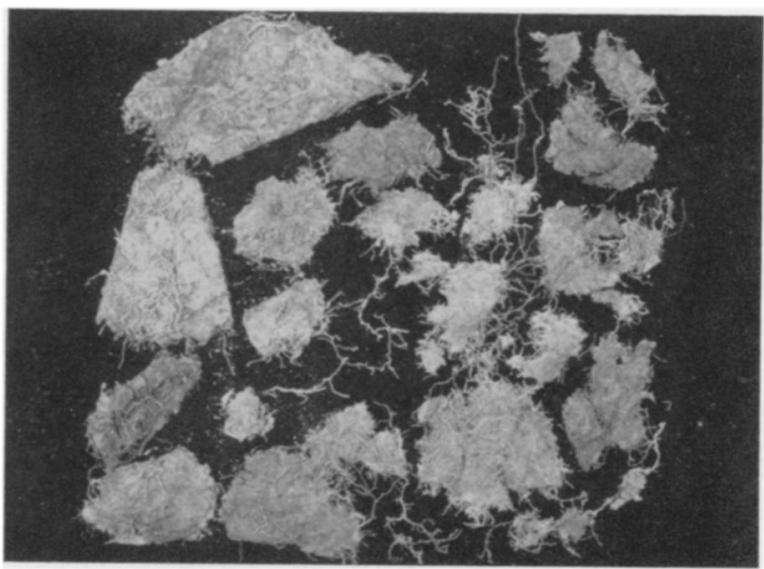

FIG. 19. Roots of western wheat grass matted on the rock (left), and root-mats lying just above it (right). These were taken at a depth of 38 inches in a Rendzina soil.

\section{ROOT DISTRIBUTION IN MELLOW LOESS SOILS}

In central Nebraska there are several thousand square miles of loess hills. Much of this area is range land and is elothed with short grasses, the roots penetrating deeply or more shallowly depending upon the texture, structure, maturity, and stability of the various types of soil. In general the soils are very fine textured, consisting mostly of silt, approximately a third of clay, and smaller percentages of very fine sand. The organic matter usually ranges from 4 to 4.5 percent and the total nitrogen often ranges from 0.13 to 0.20 percent. The soil is highly erosive. Precipitation at Kearney, where these studies were made, is 23.9 inches.

\section{Blue Grama in (10) Hastings Silt Loam}

Roots from the monolith taken on a nearly level hilltop in the Sheen pasture are shown in figure 20. There was a good stand of blue grama in the deep silt loam soil which is a fairly representative sample of Hastings silt loam, a typical Chernozem. It is interesting to note that here there is a typical Chernozem on the smooth hilltop associated closely with the Sherman silt loam, a Chestnut soil on the adjacent 


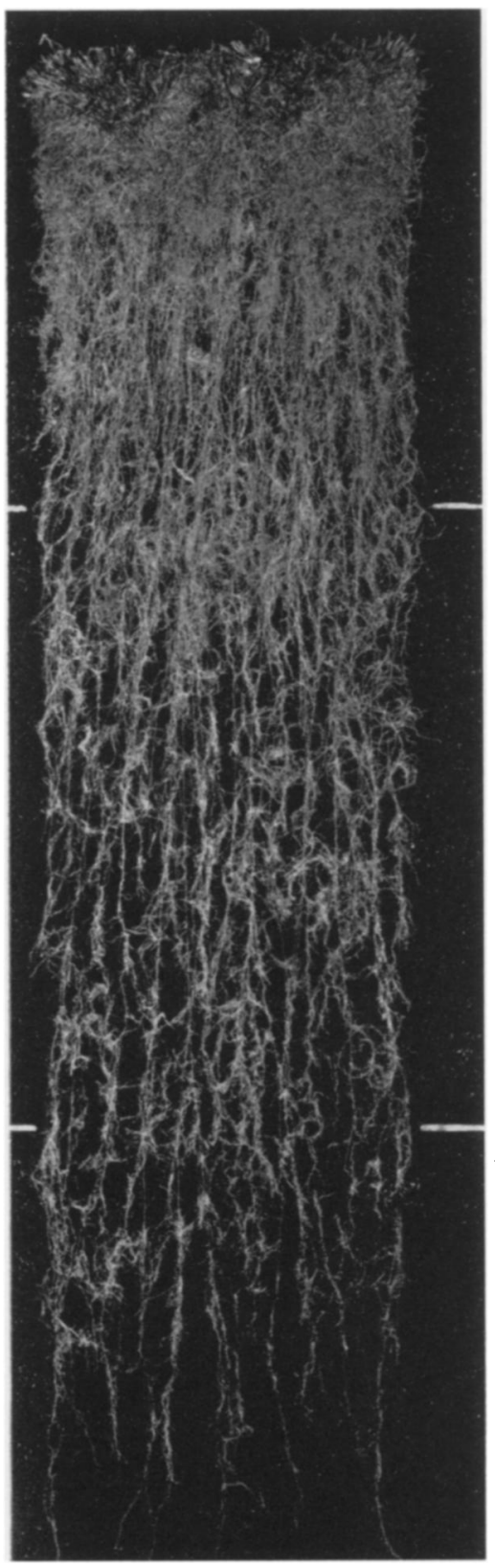

FIG. 20. Upper 4 feet of the root system of blue grama in (10) Hastings silt loam on a loess hill near Kearney. Note the great density of the root mass in the A horizon (0-15 in.). This, when dried, was found to compose 91 percent of the entire root-weight; only about 8 percent was found in the B (15 to 35 in.) horizon. But some absorption also occurred in the $\mathrm{C}$ horizon.

rather steep slope. At least part of the differences between the two soils can be ascribed to differences in moisture relationships brought about by differences in slope gradient. Also important is that the Hastings silt loam shows little or no evidence of a second soil formed from relatively new loess in the upper part of the profile as does the Sherman silt loam to be described.

\section{HASTINGS SILT LOAM}

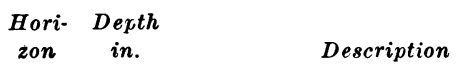

A 0 - 8 Dark gray (10YR 4/1 dry) to black (10YR 2/1 moist) silt loam; soil breaks into thin plates and fine granules; friable; $\mathrm{pH} \mathbf{7 . 0}$

$A_{3}$ 8-15 Very dark grayish brown (10YR 3/1.5 dry) to very dark brown (10YR $2 / 2$ moist) heavy silt loam; granular structure; friable; $\mathrm{pH} 7.0$

$\mathrm{B}_{2} \quad \mathbf{1 5 - 2 5}$ Dark grayish brown (2.5Y 4.5/2 dry) to very dark grayish brown (2.5Y $3.5 / 2$ moist) heavy silty clay loam; fine prismatic aggregates breaking into blocks; plastic; $\mathrm{pH} \mathbf{7 . 3}$

$B_{3}$ 25-35 Light olive brown (2.5Y $\left.5.5 / 4 \mathrm{dry}\right)$ to olive brown (2.5Y 4.5/4 moist) light silty clay loam; blocky structure; moderately friable; pH 7.5

$C_{1} \quad 35.48$ Light yellowish brown $(2.5 Y$ Y.5/4 dry, with white spots) to light olive brown (2.5Y 5.5/4 moist, with white spots) heavy silt loam; massive; friable; calcareous

Roots were especially abundant in the deep A horizon (0-15 in.). At greater depths roots were fewer but they continued to branch profusely to a depth of 4 feet. A few extended beyond the monolith to approximately 5 feet.

\section{Blue Grama in (11) Colby Silut Loam}

Quite in contrast to this excellent development was the much lighter root system obtained from Colby silt loam under approximately the same mean annual rainfall of about 23 inches. The monolith was taken on a slope of only 3 percent gradient in a large prairie 5 miles southeast of Broken Bow, Nebraska.

\section{COLBY SILT LOAM ${ }^{1}$}

The so-called Colby silt loam is typical of the soil as mapped in much of central and western Nebraska, but is leached somewhat deeper and has a slightly thicker dark surface soil than some Colby soils in this state. Much of the Colby soil of Nebraska is essentially the same in texture throughout the profile.

\begin{tabular}{|c|c|c|}
\hline $\begin{array}{c}\text { Hori- } \\
\text { zon }\end{array}$ & $\begin{array}{c}\text { Depth } \\
\text { in. }\end{array}$ & Description \\
\hline$A_{1-1}$ & $0.3 / 4$ & $\begin{array}{l}\text { Grayish brown (10YR } 4 / 2 \text { dry) to dark gray- } \\
\text { ish brown ( } 10 \mathrm{YR} 3 / 2 \text { moist) silt loam; medium } \\
\text { to fine crumb structure; friable; pH } 7.0\end{array}$ \\
\hline$A_{1-2}$ & $3 / 4-4$ & $\begin{array}{l}\text { Grayish brown (10YR } 5 / 2 \text { dry) to grayish } \\
\text { brown (10YR } 4 / 2 \text { moist) silt loam; granular } \\
\text { or crumb structure; friable; pH } 7.0\end{array}$ \\
\hline$A_{1-3}$ & 4-12 & $\begin{array}{l}\text { Grayish brown (10YR } 4.5 / 2 \text { dry) to dark } \\
\text { grayish brown (10YR } 3.5 / 2 \text { moist) heavy silt } \\
\text { loam; granular structure with prismatic cleav- } \\
\text { age; friable when moist, slightly plastic when } \\
\text { wet; pH } 7.0\end{array}$ \\
\hline $\mathbf{B}_{1}$ & $12 \cdot 20$ & $\begin{array}{l}\text { Grayish brown (10YR } 5 / 2 \text { dry) to grayish } \\
\text { brown (10YR } 4 / 2 \text { moist) light silty clay loam; } \\
\text { medium prismatic and nuciform granular struc- } \\
\text { ture; slightly plastic when moist to plastic when } \\
\text { wet; pH } 7.0\end{array}$ \\
\hline $\mathrm{C}_{1}$ & $20-32$ & $\begin{array}{l}\text { Olive brown (2.5Y } 5.5 / 3 \text { dry) to dark olive } \\
\text { brown }(2.5 \mathrm{Y} 4.5 / 3 \text { moist }) \text { silt loam; prismatic } \\
\text { and coarse nuciform structure; friable; pH } 7.5\end{array}$ \\
\hline $\mathrm{C}_{2}$ & $2 \cdot 46$ & $\begin{array}{l}\text { Light olive brown (2.5Y } 6 / 3 \mathrm{dry}) \text { mottled with } \\
\text { yellowish brown (10YR } 5 / 4 \mathrm{dry}) \text { to grayish }\end{array}$ \\
\hline
\end{tabular}

1 This soil has been called Colby silt loam over a wide area in Nebraska, but it is darker colored than the Colby silt loam of eastern Colorado and western Kansas. It resembles closely the Ulysses silt loam, a series recognized tentatively in western Kansas. 
brown ( $2.5 \mathrm{Y} 4.5 / 2$ moist) mottled with yellowish brown (10YR 4/4 moist) silt loam; coarse prismatic structure; friable; calcareous; $\mathrm{pH} \mathbf{8 . 0}$

$c_{3}$ 46-48 Light brownish gray $(2.5 \mathrm{Y} 6 / 2$ dry $)$ mottled white $(2.5 \mathrm{Y} 9 / 2 \mathrm{dry})$ to grayish brown $(2.5 \mathrm{Y}$ 4.5/2 moist) mottled white (2.5Y $8 / 2$ moist) silt loam; coarse prismatic structure grading to massive; very friable; calcareous; $\mathrm{pH} 8.0+$

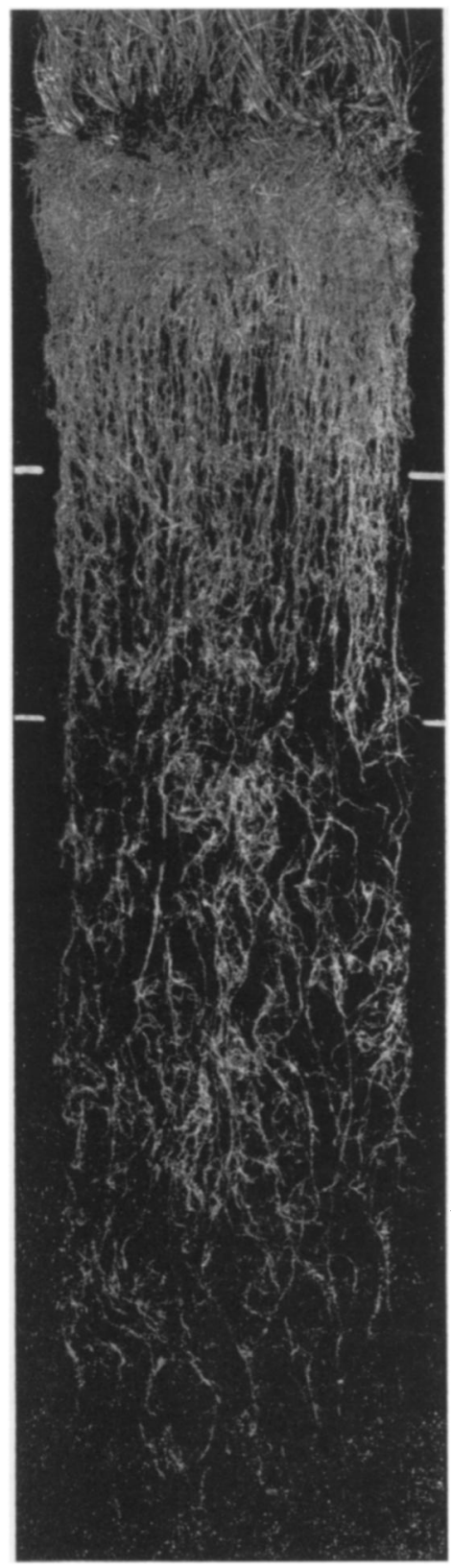

Fig. 21. Four feet of the root system of blue grama in (11) Colby silt loam. There is much less root material at all depths than in the same species growing in the more mature (10) Hastings silt loam, in figure 20.

Even casual examination of figure 21 shows that greatest concentration of roots was in the A horizon (0-12 in.) of this shallow solum. Even this layer was relatively poorly occupied; one-fourth less material was found here than in the first foot in the heavier (10) Hastings silt loam. Differences at greater depth were even more marked. Depth of penetration was approximately 5.5 feet, the roots ending in very moist, limy parent loess.

\section{Buffalo Grass in (12) Holdrege Silt Loam}

The roots in a uniformly thick, pure stand of Buchloe dactyloides were studied on a nearly level upland in the McCan experimental pasture 1 mile northwest of Kearney, Nebraska (Weaver \& Bruner 1948). The soil is Holdrege silt loam. It has about the maximum content of clay in the B horizon for this type but it is definitely within the range of the Holdrege series.

\begin{tabular}{|c|c|c|}
\hline & & \\
\hline $\begin{array}{c}\text { Hori- } \\
\text { zon }\end{array}$ & $\begin{array}{c}\text { Depth } \\
\text { in. }\end{array}$ & Description \\
\hline $\begin{array}{l}\text { Recent } \\
\text { dust ac- } \\
\text { cumula- } \\
\text { tion }\end{array}$ & $0-1$ & $\begin{array}{l}\text { Grayish brown (10YR } 5 / 2 \text { dry) to very dark } \\
\text { grayish brown ( } 10 \mathrm{YR} 3 / 2 \text { moist) silt loam of } \\
\text { fine-crumb structure; friable, dry and moist; } \\
\text { pH } 6.5\end{array}$ \\
\hline$A_{1-1}$ & 1- 6 & $\begin{array}{l}\text { Dark grayish brown (10YR } 4 / 1.5 \text { dry) to very } \\
\text { dark grayish brown (10YR } 3 / 1.5 \text { moist) silt } \\
\text { loam; fine-crumb structure, vertical cleavage; } \\
\text { friable, dry and moist; pH } 6.5\end{array}$ \\
\hline $1-2$ & $6-12$ & $\begin{array}{l}\text { Dark grayish brown (10YR } 4 / 2 \text { dry) to very } \\
\text { dark grayish brown (10YR } 3 / 2 \text { moist) silt } \\
\text { loam; strong, fine to medium granular structure, } \\
\text { vertical cleavage; friable, dry and moist; pH } 6.8\end{array}$ \\
\hline $\mathbf{B}_{1}$ & $12 \cdot 15$ & $\begin{array}{l}\text { Dark grayish brown (10YR } 4 / 2 \text { dry) to very } \\
\text { dark grayish brown (10YR } 3 / 2 \text { moist) light silty } \\
\text { clay loam; prismatic-nuciform-granular (com- } \\
\text { pound) structure with strong vertical cleavage; } \\
\text { friable, dry; slightly plastic, moist to wet; pH } \\
6.8\end{array}$ \\
\hline$B_{2-1}$ & $15 \cdot 22$ & $\begin{array}{l}\text { Grayish brown (10YR } 5 / 2 \text { dry) to dark grayish } \\
\text { brown (10YR } 4 / 2 \text { moist) silty clay loam; pris- } \\
\text { matic-nuciform-granular (compound) structure } \\
\text { with strong vertical cleavage, primary aggregates } \\
1 / 2 \text { to } 3 / 4 \text { inch in diameter; friable, dry; } \\
\text { moderately plastic, moist and wet; pH } 7.0\end{array}$ \\
\hline$B_{2-2}$ & $22-28$ & $\begin{array}{l}\text { Light brownish gray (10YR } 6 / 1.5 \text { dry) to gray- } \\
\text { ish brown (10YR } 5 / 1.5 \text { moist) silty clay loam; } \\
\text { imperfect prismatic-nuciform structure; friable, } \\
\text { dry; moderately plastic, moist and wet; pH } 7.0\end{array}$ \\
\hline $\mathbf{B}_{3}$ & $28-36$ & $\begin{array}{l}\text { Light yellowish brown }(2.5 \mathrm{Y} 6 / 3 \text { dry }) \text { to light } \\
\text { olive brown ( } 2.5 \mathrm{Y} 5 / 3 \text { moist }) \text { heavy silt loam; } \\
\text { imperfect prismatic, weakly nuciform secondary } \\
\text { aggregates; friable, dry; slightly plastic, moist } \\
\text { and wet; pH } 7.5\end{array}$ \\
\hline $\begin{array}{l}\text { Bea } \\
\text { or } \\
\mathrm{C}_{1}\end{array}$ & $36-48$ & $\begin{array}{l}\text { Mottled pale yellow and white }(2.5 \mathrm{Y} 7 / 4,8 / 1 \\
\text { dry) to light yellowish brown }(2.5 \mathrm{Y} 6 / 3 \text { moist }) \\
\text { silt loam; prismatic to massive structure; friable, } \\
\text { moist and dry; pH } 8.0 \text {; soft lime carbonate; lime } \\
\text { concretions }\end{array}$ \\
\hline
\end{tabular}

The roots were traced in the walls of a trench to a depth of 6 feet, where they ended after extending well into the lime layer. But in one end of the trench deep soil was dry and no roots were found beyond 4.5 feet. Those obtained in a monolith 4 feet long are shown in figure 22. Although these fine, tough roots were branched throughout their length, the greatest branching occurred in the A horizon (0-12 in.) and its transition into the $B$ horizon ( $B_{1}$ 12-15 in.). At greater depths they decreased very rapidly in dry weight. The uniformity of distribution is interesting and the depth remarkable for a low-growing grass that was frequently moderately grazed to a height of 2.5 inches. 


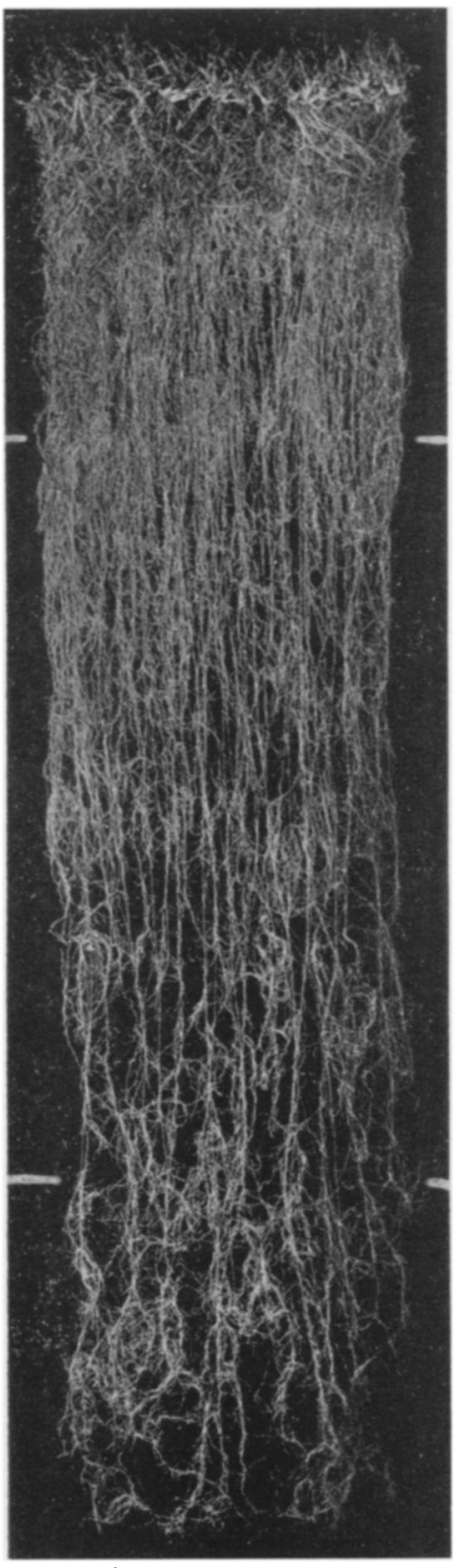

Fig. 22. Root system of buffalo grass (Buchloe dactyloides) taken from Holdrege silt loam on a nearly level upland near Kearney, Nebraska. The roots are from a 4 -foot monolith. There were about 330 main roots at a depth of 6 inches but only 153 at 12 inches depth. At 2,3 , and 4 feet the numbers were 51,30 , and 22 , respectively.

This well developed root system appears very similar to that of blue grama with which this species is often associated in the same type of soil. It differs, however, in two respects. Underground parts in the 0-6 inch layer were 49 percent greater in blue grama in (10) Hastings silt loam. But below 3 feet materials were only half as great as in buffalo grass in (12) Holdrege silt loam.
Buffalo Grass in (13) Wabash Silm Loam

The flat-bottomed valleys between the hills were originally clothed with bluestems, perhaps chiefly big bluestem. During a long period of settlement and grazing by livestock the original vegetation had been replaced by a stand of buffalo grass. This had effectually prevented erosion, at least in the upper part of the valley. The buffalo grass flourished even under constantly close grazing (usually to about 1.5 inches) from early spring until late fall (Weaver \& Bruner 1948). During these years a fill of 12 inches from silty upland soils had been washed in on top of the former soil.

The monolith was taken from bottomland in the MeCan pasture; 1 mile northwest of Kearney. The exact correlation of this soil is not presently known, but it has many characteristics like the Wabash silt loam, developed from recent alluvium, farther east in Nebraska. For practical purposes, it could be grouped with the Wabash silt loam, even though a careful field study may show that another name would be better. The Wabash silt loam has eommonly been classified as an alluvial soil, which means that it is essentially stratified alluvial deposit in which there has been very little soil development. Actually most of the Wabash soils have been in place long enough for much organic matter to accumulate. Furthermore, drainage in Wabash soils is imperfect, and the relatively high water table causes a rather strong mottling and streaking in the lower part of the profile. This would tend to place the soil in the category of Wiesenboden (imperfectly drained meadow) soils. Wabash soils are associated most typically with the black Prairie soils of Iowa and eastern Nebraska. This soil is associated with the Chernozems of central Nebraska.

\begin{tabular}{|c|c|c|}
\hline \multicolumn{3}{|c|}{ 3. WABASH SILT LOAM IN CHERNOZEM AREA } \\
\hline $\begin{array}{c}\text { Hori- } \\
\text { zon }\end{array}$ & $\begin{array}{c}\text { Depth } \\
\text { in. }\end{array}$ & Description \\
\hline (Fill) & $0-12$ & $\begin{array}{l}\text { Grayish brown (10YR } 5 / 2 \text { dry) to very dark } \\
\text { grayish brown (10YR } 3 / 2 \text { moist) light silty clay } \\
\text { loam; laminated; friable; pH } 7.0\end{array}$ \\
\hline$A_{1-1}$ & $12 \cdot 26$ & $\begin{array}{l}\text { Dark gray (10YR } 4 / 1 \text { dry) to black (10YR } 2 / 1 \\
\text { moist) heavy silt loam; medium granular struc- } \\
\text { ture; friable; pH } 7.0\end{array}$ \\
\hline$A_{1-2}$ & $26-36$ & $\begin{array}{l}\text { Grayish brown }(2.5 \mathrm{Y} 5 / 1.5 \text { dry }) \text { to very dark } \\
\text { grayish brown }(2.5 \mathrm{Y} 3 / 1.5 \text { moist }) \text { light silty } \\
\text { clay loam; granular to weakly prismatic; friable; } \\
\text { pH } 6.5\end{array}$ \\
\hline $\mathrm{C}_{1}$ & $36-44$ & $\begin{array}{l}\text { Light yellowish brown }(2.5 \mathrm{Y} 6 / 3 \text { dry }) \text {, streaked } \\
\text { with brown and light gray, to light olive brown } \\
(2.5 \mathrm{Y} 5 / 3 \text { moist }) \text {, also streaked, light silty clay } \\
\text { loam; weakly granular structure; friable; pH } 6.0\end{array}$ \\
\hline $\mathrm{C}_{2}$ & $44-48$ & $\begin{array}{l}\text { Light olive brown }(2.5 \mathrm{Y} / 3 \mathrm{dry}) \text {, streaked with } \\
\text { brown and light gray, to slightly darker colored } \\
\text { moist; silt loam; laminated; friable; pH } 6.0\end{array}$ \\
\hline
\end{tabular}

When the roots were examined in a deep excavation they were found in abundance to 5 feet in depth and some extended to 6.5 feet. Those from a 4-foot monolith are shown in figure 23 .

The mass of roots was especially dense in the 12 inches of fill. But even to a depth of 2.5 feet the root system was remarkably developed. The deep, well drained soil was usually more moist and also wet 


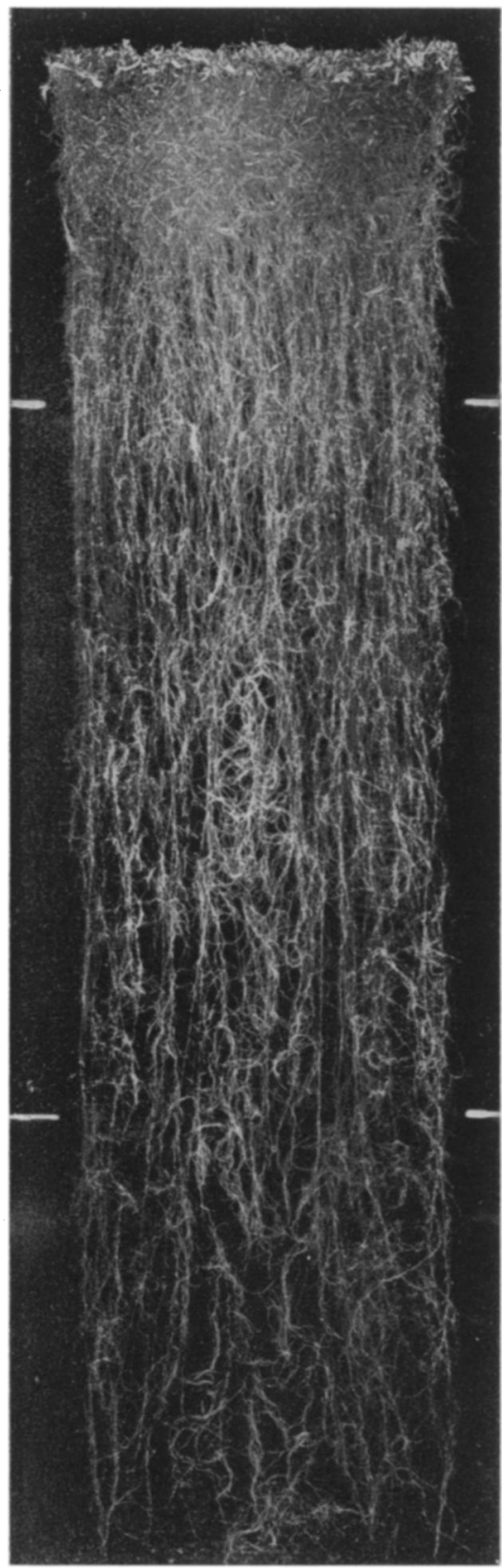

Fic. 23. Four feet of roots of buffalo grass taken from Wabash silt loam in a valley about 300 yards from the trench in Holdrege silt loam on the hilltop. Note how mueh deeper than in figure 22 the massive portion of the root system extends. Upper lines mark the depth of the 12-inch fill; lower ones the depth of the A horizon, 36 inches.

to a greater depth than that of the upland from which snow was blown and runoff water ran down the slopes. Moreover, these loess soils are fairly low in both nitrogen and phosphorus. Undoubtedly supplies of these nutrients were greater in the lowland soils as a result of the soil and organic matter deposited there. Organic phosphorus is most readily available to the growing plant, and this too may have prom:oted greater root development, despite the more constant and closer grazing, than on upland. A comparison of figure 23 with figure 22 clearly reveals a much heavier root system in the (13) Wabash silt loam. Dry weight of underground parts in grams in the first two 6-inch levels and then foot by foot was consistently less in (12) Holdrege silt loam. They were as follows: 15.1 and $17.1 ; 2.5$ and $2.9 ; 2.4$ and $2.6 ; 0.8$ and 1.3 ; 0.6 and 0.7 .

\section{Buffalo Grass in (14) Sherman Silut Loam}

This monolith was taken from a slope in Sheen's pasture 4.5 miles west and 1 mile north of Kearney (Weaver \& Bruner 1948). There was an excellent stand of buffalo grass. The slope had a gradient of 11 percent with a westerly aspect. While this soil occurs in the Chernozem zone, it is near the zone's western edge, and the soil itself has more characteristics like Chestnut soils than like Chernozem soils. Probably this is because the rather steep gradient of the land and the slope toward the west had reduced the effectiveness of the moisture. It appears that the soil as sampled actually has a "double profile." The soil at a depth of 17 inches represents the original surface on which a rather well-developed Chernozem soil was formed. Following the formation of this Chernozem soil, loess was deposited to a depth of about 17 inches and a new soil was formed from this new loess deposit. Hence, there is a succession of $A_{1-1}, A_{1-2}$, and $A_{3}$ horizons underlain by the old $A_{1-1}$ and $A_{1-2}$ horizons that were formed before the material of the upper part of the soil was deposited. This explains the peculiar designations of horizons which appear in the following description. The closest correlative of this soil is the Sherman silt loam, and it is believed that this correlation will be satisfactory.

\section{SHERMAN SILT LOAM}

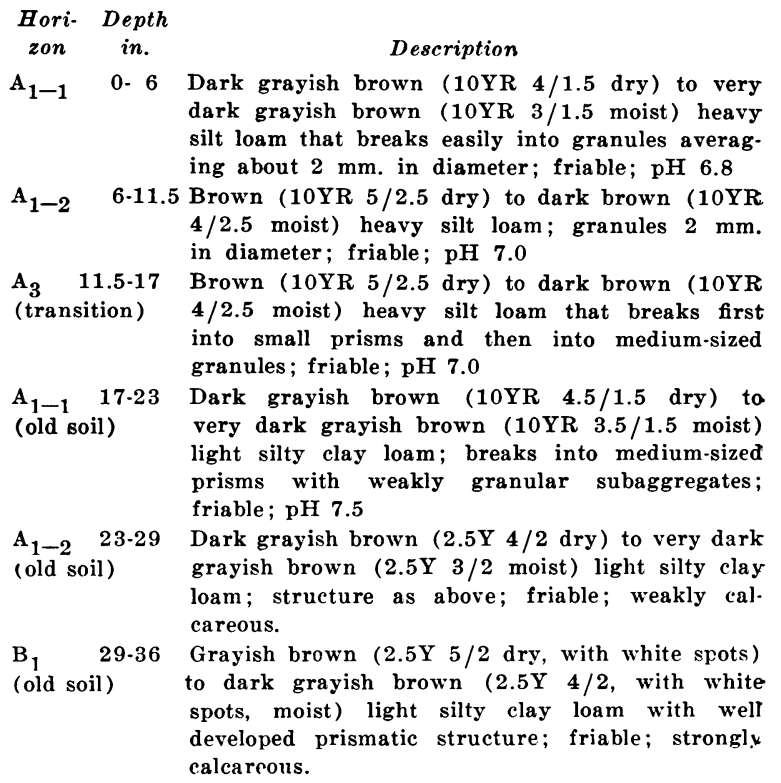


This root system was somewhat better developed at all depths than either of the preceding samples of buffalo grass. In both (12) Holdrege and (13) Wabash silt loam the weight of roots in the second foot was slightly less than that in the second 6-inch layer. But in (14) Sherman silt loam there was a small increase in weight in the second foot. The $A_{1-1}$ horizon of the old soil (17-23 inches depth) is included in the second foot and probably accounts for this increase. Three other samples of roots of buffalo grass in this soil gave similar results. Roots extended far beyond the 3-foot monolith, some reaching a depth of 6 feet.

\section{Various Species in Azonal Soll of the Loess}

In the loess hills of central Nebraska some lowgrade grasslands have resulted from abandoning cultivated land. This land was usually on such steep slopes that it should never have been broken. For many years annual and perennial weeds constitute the bulk of the scanty cover of vegetation. Perennial grasses enter and increase slowly. A part of the pasture $(80$ acres) from which the following monoliths were taken had been broken for raising crops and then abandoned 25 years ago. As a result erosion by wind and water had removed all of the solum ( $\mathrm{A}$ and B horizons) over considerable areas of the steeper slopes. They were now partly clothed with small patches of blue grama, buffalo grass, and western wheat grass alternating with more extensive stands of three-awn grasses (Aristida purpurea and $A$. oligantha), although weeds and certain other species of grasses were common.

Monoliths were taken on a slope of 11 percent in an area mapped as Colby silt loam. There was a very thin, poorly developed new $A_{1}$ horizon only 2 to 3 inches deep. The soil is of loessal parent material, rich in lime throughout which is often in concretions, and with a $\mathrm{pH}$ of 8 . The same light yellow color prevailed from the soil surface to 4 feet in depth. The lime layer began at a depth of 5.5 to 7.5 inches and was still present at 4 feet.

\section{BLUE GRAMA}

The soil around bunches and small patches of blue grama was often eroded several inches below the plant crowns. Sometimes living bunches of this grass extended 7 to 8 inches above the level of the surrounding soil. Although a good stand of blue grama was selected for the monolith, similar blocks of adjoining sod broke up easily as did those of all the other grasses examined. Only a very few roots extended beyond the 3-foot monolith although the soil in each of 5 trenches (except under western wheat grass) was moist to greater depths (Fig. 24). Although the weight of the upper 6 inches of roots of blue grama ( $28.7 \mathrm{gm}$.) exceeded that of the same species in upland Hastings silt loam (22.5 gm.), the remainder of the root system to 3 feet weighed 37 percent less. Moreover, it was 12 to 18 inches shallower.

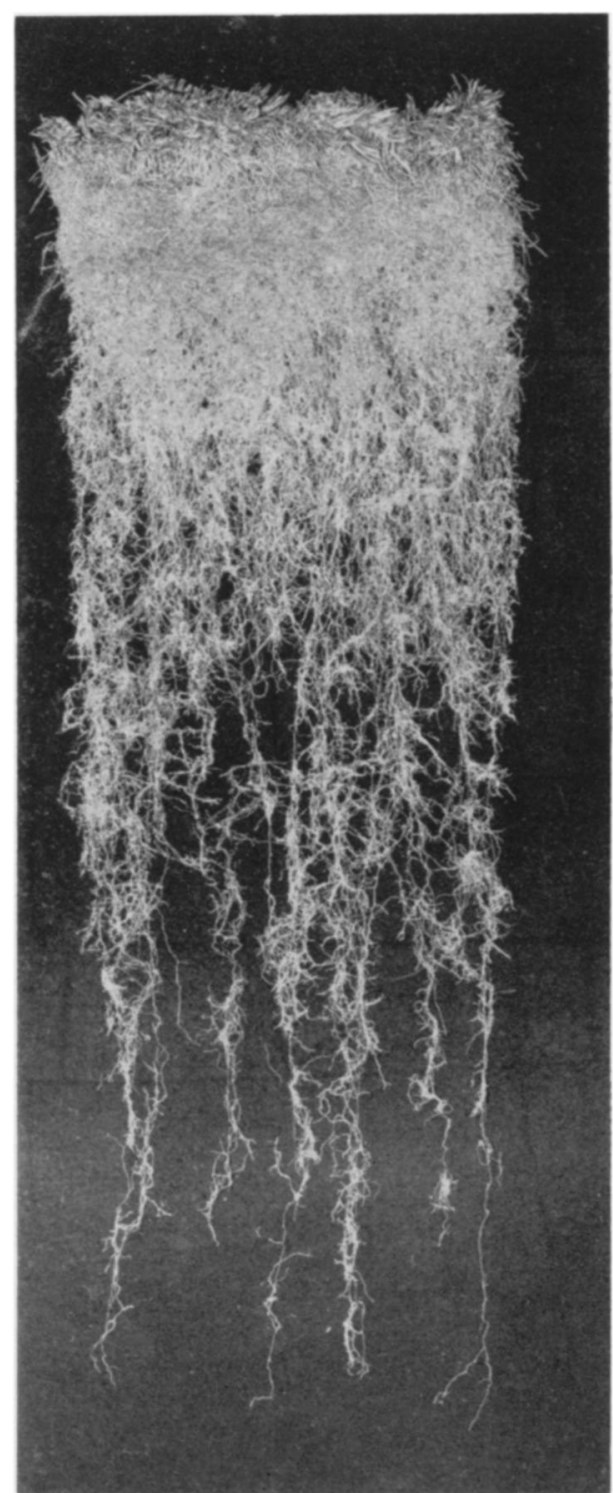

Fig. 24. Roots of blue grama in a 3-foot monolith taken in deeply eroded loess. Nearly all of the roots are concentrated in the surface 12 to 14 inches of soil. The deeper roots appear very different from those taken in mature soil (10, Hastings silt loam) in the same pasture (Fig. 20).

\section{BUFFALO GRASS}

In the patches of buffalo grass the ungrezed midsummer foliage had a height of only 1.5 to 2.5 inches. The stand was only half that on mature soil. Despite the yellow-green color and stunted condition of the foliage the plants had produced flowers and some seed. A mass of roots occurred only in the first foot. They were very thin and poorly developed deeper (Fig. 25). In the surface 6 inches the underground parts weighed only about a fourth as much as those of blue grama. At greater depths the roots were 


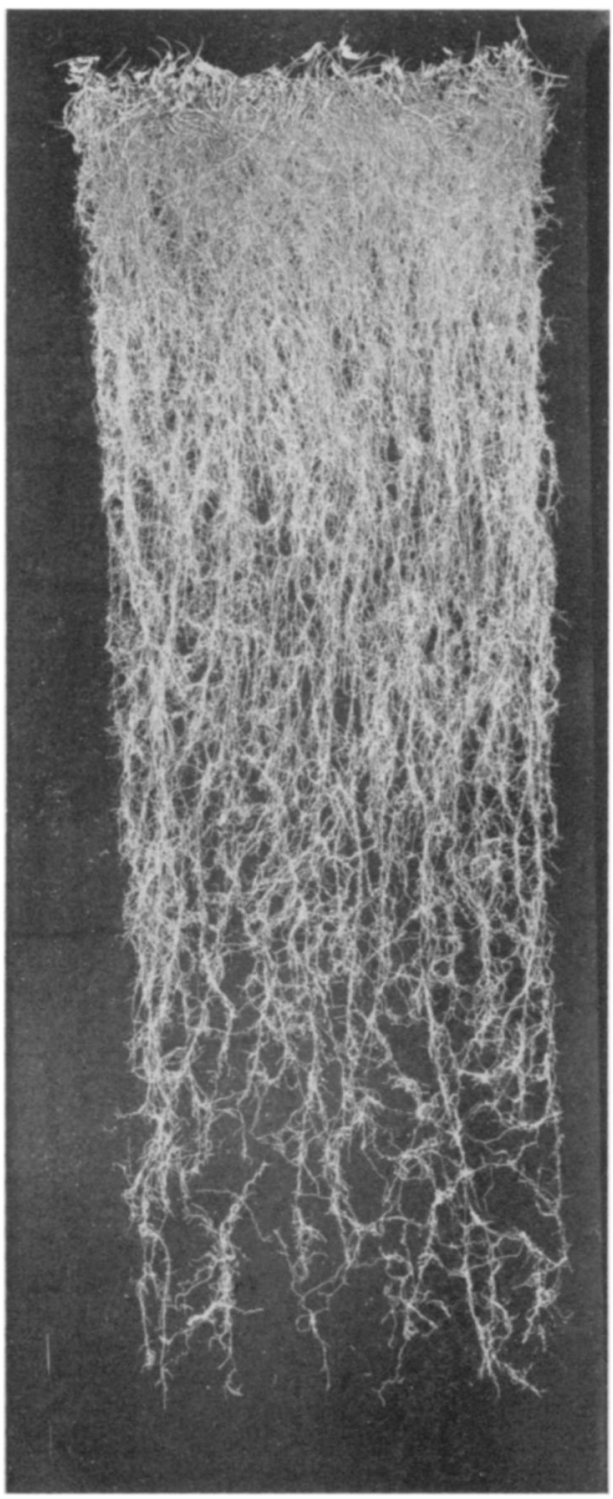

Fig. 25. Root system of buffalo grass to a depth of 3 feet showing the relatively poor development when growing on loess subsoil.

heavier than those of blue grama and they extended a little deeper. But only rarely was a root found below 36 inches.

Comparison was made of this abbreviated root system with that of buffalo grass growing in well developed soil (Fig. 22). The mass of buffalo grass roots in the surface 6 inches was about half that of the same grass in Holdrege silt loam. The total root weight to 3 feet in depth was only slightly more than half as great.

\section{SAND DROPSEED}

Sporobolus cryptandrus grew here in stands about two-thirds as dense as those found on mature soil. The tops were greatly dwarfed. Here also the roots in the monolith were very abundant to 15 inches depth, below which they became much sparser. There were few below 2 feet and only rarely was one found deeper than the 3-foot level. Normally this species has a well developed root system 4 to 5 feet deep.

\section{WESTERN WHEAT GRASS}

Western wheat grass was taken in a monolith only a few yards distant from the preceding trenches and on the same slope. This profusely and deeply rooted species had previously been, studied in the Colby silt loam in another site about half a mile distant

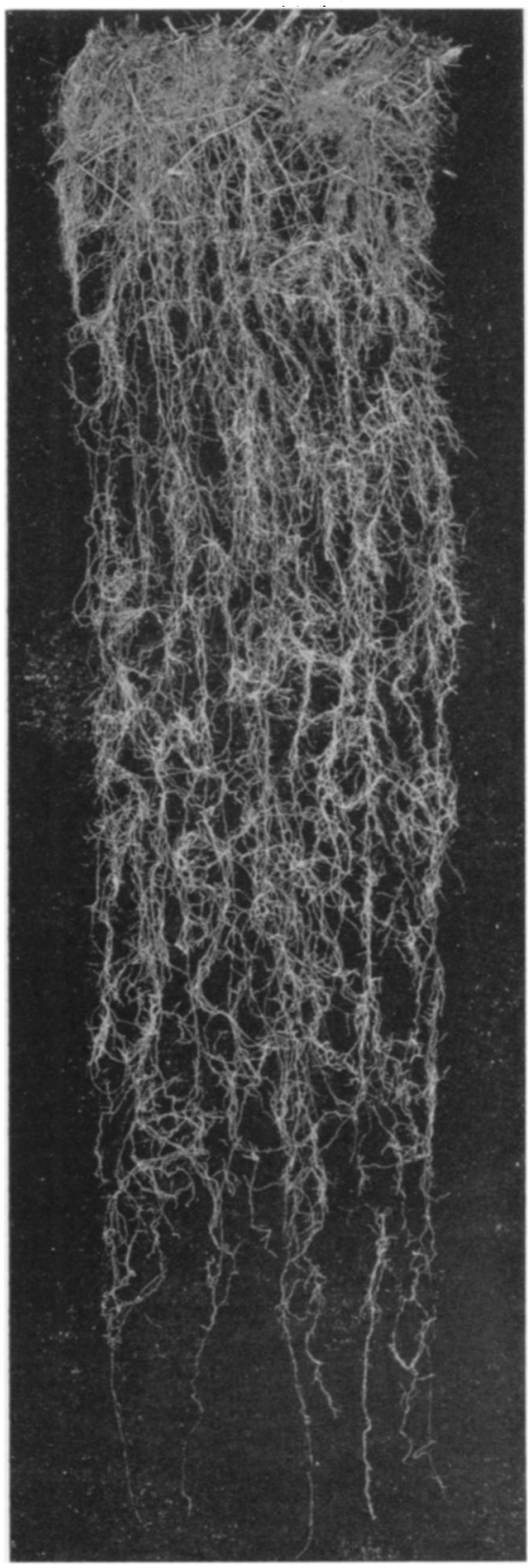

Fig. 26. Roots of western wheat grass from a 4-foot monolith of azonal soil of the loess. Comparison with roots of this species in figure 9 reveals the poor development at all levels in this impoverished, immature soil. 
(Weaver \& Bruner 1948). There the abundant roots penetrated vertically downward, some extending into the moist subsoil to a depth of 10 feet. But on this eroded hillside the stand was only half normal and the plants were dwarfed. The roots were proportionately few. All but 4 or 5 of the deepest were taken in their entirety in the 4-foot monolith (Fig. 26). Depth of penetration seemed not to be hindered by lack of available water, since the soil was moist below 4 feet in all the trenches.

\section{PURPLE THREE-AWN}

A monolith with Aristida purpurea was taken on the same slope. This perennial is extremely common in subseres. As shown in figure 27, the bulk of the roots spread laterally and soon extended beyond the width of the monolith. But some grew downward in a manner similar to that of grasses previously described.

The root habits of this species have been examined by the senior author in several sites on the Great Plains of Colorado. In nearly all it was not unlike that of other grasses in regard to a rather vertical direction of penetration. The depth varied from 2.3 to 3.5 feet. Even in the exceedingly compact Pierre clay at Ardmore, South Dakota, the depth of penetration of most roots was 2.6 feet below the crown of the plant, although some penetrated 6 inches deeper. But at Yuma, Colorado, the plants grew in coarse sand which was firmly compacted. Here the roots all spread widely, even 3 to 4 feet from the crown and practically the entire root system was in the surface 2 feet of soil. In a broad valley, about a mile distant, the compacted sand was somewhat intermixed, at least near the surface, with some black soil and humus. Here the roots had a very wide lateral spread in the shallow soil. Some ran off nearly parallel with the soil surface at depths of only 2 to 6 inches for distances of about 2 feet. The surface 1.5 feet of soil was especially occupied by the coarse but well branched roots. However, about a fourth of the whole root system penetrated rather vertically downward, so that the soil beneath the plant was also well occupied (Weaver 1920). This variation of the root system of purple three-awn with the environment may be a large factor in its success in development on eroded soils.

\section{AMOUNT OF ROOTS IN EACH FOOT OF SOIL}

The actual weight and percentage of the weight of each root system that occurred in each 6 inches or foot of soil are shown in the following tables. For convenience of comparison, each species is discussed separately.

\section{Big Bluestem}

There is a wide range in the weight of underground materials where big bluestem grew in different types of soil. In the surface 6 inches this range is from 16.84 to 53.49 grams (Table 2). In the second 6 inches, where the amounts are invariably much smaller, the range is from 2.02 to 8.20 grams. Without exception, roots in the second foot weighed less than those in the second 6 -inch layer. Here the range in weight is from 1.79 to 7.40 grams. Root-weight in the third foot always shows a sharp decrease over that in the second foot. The weight ranges from 0.56 to 3.70 grams. As little root-weight as 0.17 gram occurs in the fourth foot and no plant produced more than 1.24 grams. In several soil types there were no roots in the fifth foot; the largest amount recorded was 0.51 gram.

By comparing root-weight in upland soil types $(2,5,15)$ it may be seen that the smallest amounts at all depths were in compacted (2) Carrington silty

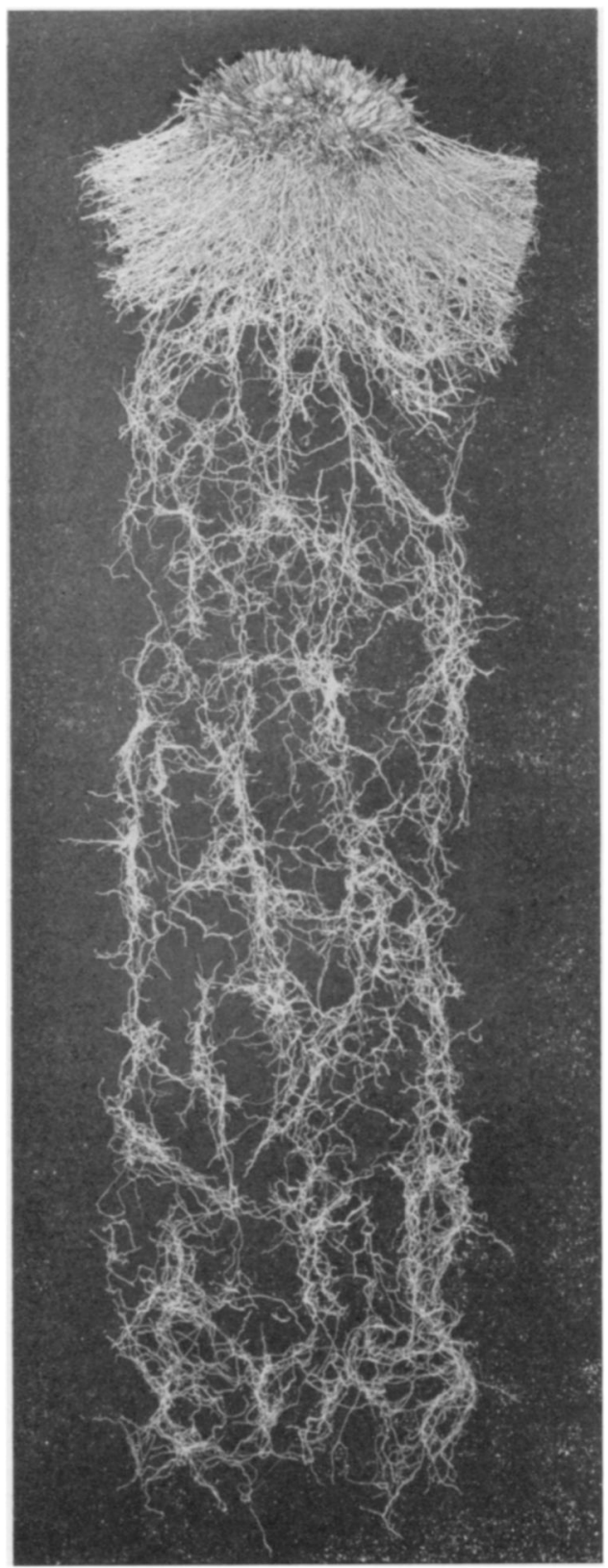

FIG. 27. Portion of the root system of purple threeawn (Aristida purpurea) from a 3 -foot monolith taken in azonal soil. Unlike all of the preceding grasses, most of the roots spread widely in the surface soil. 
TABLE 2. Distribution of root systems at each of the several depths and percentage of roots at each depth.

\begin{tabular}{|c|c|c|c|c|c|c|c|c|c|c|c|c|c|}
\hline Spp. & Depth & \multicolumn{2}{|c|}{$\begin{array}{l}2 \text { Carrington } \\
\text { silty clay loam }\end{array}$} & \multicolumn{2}{|c|}{$\begin{array}{c}5 \text { Crete } \\
\text { silty clay loam }\end{array}$} & \multicolumn{2}{|c|}{$\begin{array}{l}1 \text { Sharpsburg } \\
\text { silty clay loam }\end{array}$} & \multicolumn{2}{|c|}{$\begin{array}{l}3 \text { Wabash } \\
\text { silty clay loam }\end{array}$} & \multicolumn{2}{|c|}{$\begin{array}{l}4 \text { Judson } \\
\text { silt loam }\end{array}$} & \multicolumn{2}{|c|}{$\begin{array}{l}7 \text { Crete } \\
\text { silt loam }\end{array}$} \\
\hline \multirow{3}{*}{$A f^{1}$} & & gm. & $\%$ & gm. & $\%$ & gm. & $\%$ & gm. & $\%$ & gm. & $\%$ & gm. & $\%$ \\
\hline & $\begin{array}{r}0-6 \\
6-12 \\
12-24 \\
24-36 \\
36-48 \\
48-60\end{array}$ & $\begin{array}{r}17.45 \\
2.65 \\
2.34 \\
.57 \\
.17\end{array}$ & $\begin{array}{r}75.3 \\
11.4 \\
10.1 \\
2.5 \\
.7\end{array}$ & $\begin{array}{c}28.70 \\
3.72 \\
2.60 \\
1.19 \\
.46^{*}\end{array}$ & $\begin{array}{r}78.3 \\
10.1 \\
7.1 \\
3.2 \\
1.3\end{array}$ & $\begin{array}{c}33.35 \\
4.49 \\
2.95 \\
1.35 \\
.66 \\
.27^{*}\end{array}$ & $\begin{array}{r}77.5 \\
10.4 \\
6.9 \\
3.1 \\
1.5 \\
.6\end{array}$ & $\begin{array}{r}16.84 \\
2.02 \\
1.79 \\
.56 \\
.19\end{array}$ & $\begin{array}{r}78.7 \\
9.4 \\
8.4 \\
2.6 \\
.9\end{array}$ & $\begin{array}{r}33.69 \\
6.84 \\
5.15 \\
2.17 \\
.85 \\
.51^{*}\end{array}$ & $\begin{array}{r}68.5 \\
13.9 \\
10.5 \\
4.4 \\
1.7 \\
1.0\end{array}$ & $\begin{array}{l}35.78 \\
8.20 \\
7.40 \\
3.70 \\
1.24^{*}\end{array}$ & $\begin{array}{r}63.5 \\
14.6 \\
13.1 \\
6.6 \\
2.2\end{array}$ \\
\hline & Total & 23.18 & & 36.67 & & 43.07 & & 21.40 & & 49.21 & & 56.32 & \\
\hline \multirow[t]{2}{*}{ A sc } & $\begin{array}{r}0-6 \\
6-12 \\
12-24 \\
24-36 \\
36-48 \\
48-60\end{array}$ & \multirow{2}{*}{\multicolumn{2}{|c|}{$\begin{array}{l}\text { P vi } \\
1 \text { Sharps- } \\
\text { burg silty } \\
\text { clay loam } \\
\text { Wt. of upper } \\
5 \text { feet only }\end{array}$}} & $\begin{array}{c}37.20 \\
6.68 \\
7.10 \\
2.86 \\
2.14 \\
1.20^{* *}\end{array}$ & $\begin{array}{r}65.1 \\
11.7 \\
12.4 \\
5.0 \\
3.7 \\
2.1\end{array}$ & $\begin{array}{r}44.60 \\
2.74 \\
2.59 \\
1.20 \\
.75 \\
.12\end{array}$ & $\begin{array}{r}85.8 \\
5.3 \\
5.0 \\
2.3 \\
1.4 \\
.2\end{array}$ & \multirow{2}{*}{\multicolumn{2}{|c|}{$\begin{array}{l}\text { A fu } \\
15 \text { Crete } \\
\text { silty clay } \\
\text { loam }\end{array}$}} & $\begin{array}{c}53.49 \\
5.63 \\
4.19 \\
1.82 \\
1.22 \\
.40^{*}\end{array}$ & $\begin{array}{r}80.2 \\
8.4 \\
6.3 \\
2.7 \\
1.8 \\
.6\end{array}$ & $\begin{array}{r}45.06 \\
5.96 \\
5.26 \\
2.50 \\
.62\end{array}$ & $\begin{array}{r}75.9 \\
10.0 \\
8.9 \\
4.2 \\
1.0\end{array}$ \\
\hline & Total & & & 57.18 & & 52.00 & & & & 66.75 & & 59.40 & \\
\hline $\mathrm{B} \mathrm{cu}$ & $\begin{array}{r}0-6 \\
6-12 \\
12-24 \\
24-36\end{array}$ & \multicolumn{2}{|c|}{$\begin{array}{l}\quad \text { In } \\
16 \text { Carrington } \\
\text { silty clay loam; } \\
\text { rolling phase }\end{array}$} & $\begin{array}{c}24.10 \\
2.50 \\
1.19 \\
.55^{*}\end{array}$ & $\begin{array}{r}85.1 \\
8.8 \\
4.2 \\
1.9\end{array}$ & & & & & $\begin{array}{c}33.17 \\
3.04 \\
2.27 \\
.56^{*}\end{array}$ & $\begin{array}{r}85.0 \\
7.8 \\
5.8 \\
1.4\end{array}$ & & \\
\hline \multirow[t]{2}{*}{ P pr } & $\begin{array}{r}\text { Total } \\
\\
0-6 \\
6-12 \\
12-24 \\
24-36 \\
36-48\end{array}$ & $\begin{array}{r}6.78 \\
1.70 \\
.41\end{array}$ & $\begin{array}{r}76.3 \\
19.1 \\
4.6\end{array}$ & 28.34 & & & & $\begin{array}{r}6.59 \\
1.08 \\
.71 \\
.06\end{array}$ & $\begin{array}{r}78.1 \\
12.8 \\
8.4 \\
.7\end{array}$ & $\begin{array}{r}39.04 \\
\\
22.04 \\
2.95 \\
2.24 \\
.32 \\
.11\end{array}$ & $\begin{array}{r}79.9 \\
10.7 \\
8.1 \\
1.1 \\
.4\end{array}$ & & \\
\hline & Total & 8.89 & & & & & & 8.44 & & 27.66 & & & \\
\hline
\end{tabular}

1A fu is Andropogon furcatus, A sc Andropogon scoparius, P vi Panicum virgatum, B cu Bouteloua curtipendula, and P pr Poa pratensis.

*In this table and those following, an asterisk indicates that a part of the root system, a small fraction of a gram, extended deeper than the level indicated. A double asterisk indicates that the species is deeply rooted and that much of the root system extended beyond the depth at which the monolith was taken.

clay loam. A somewhat heavier root system developed in (5) Crete silty clay loam. The monolith was from a trench only 12 feet from (5) Crete silty clay loam in which western wheat grass was taken. Wheat grass grew at one end of the trench, big bluestem at the other. The soil under wheat grass was very dry at all depths, that under big bluestem was moist. There was no soil shrinking to form cracks under the big bluestem, partly because the soil apparently had less clay. Depth and thickness of the several horizons were identical. This root development is considered by the senior author, who has examined many root systems of this grass, as approximately "normal" for upland (Fig. 28).

A far greater development of underground parts occurred in (15) Crete silty clay loam about 15 miles distant. Like the preceding it was located on a southeast slope. This slope of the 120 -acre prairie had been covered with dust to a depth varying from 1 to 12 inches. The sample taken was a relict bunch of big bluestem. At this time and place the dust deposit was 3.5 inches deep. The profile was examined and the roots were separated from the soil but the description is incomplete. The depths of the $A$ and $B$ horizons were 0-12 and 12-27 inches, respectively. The monolith ended in the $\mathrm{C}$ horizon at a depth of 60 inches. A few roots extended deeper. The soil of the B horizon was almost as heavy as that of (5) Crete silt loam from which western wheat grass was excavated.

Weight of roots in the surface 6 inches of (15) Crete silty clay loam was nearly twice as great as that of the preceding (5) and more than three times as great as that of the (2) first. Differences somewhat less pronounced also occurred in the second 6-inch layer. At greater depths the roots in this soil were heavier and they also extended about a foot deeper. This area had been covered with dust at two or more intervals during the great drought of 1934-40. As a result of this wurial the rhizomes became especially heavy and woody. Normally they grow in the surface 1 to 1.5 inches of soil. Here many were 3 and some 5 inches deep. This unusual growth as a result of dust-burial has been repeatedly observed in this species. The vigorous growth of the rhizomes was reflected, it seems, in the unusual development of roots. They were much larger in diameter than those of the plants just described and were quite as large 


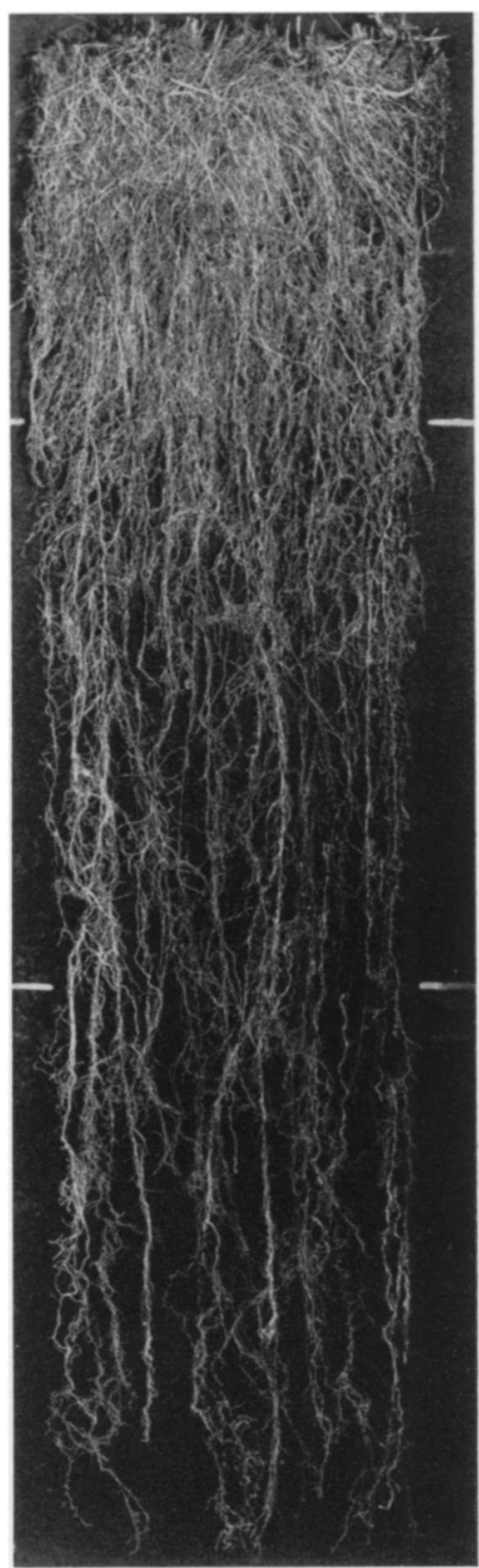

Fig. 28. Root system of big bluestem in (5) Crete silty clay loam without a claypan at Lincoln. The tops were well developed and the weight and distribution of roots is very usual for this species on upland. Note the greatest density of the mass of roots in the A horizon (0-12 in.). The $B$ horizon (12-28 in.) also has a large amount of roots; only a few extended beyond the depth (48 in.) of the monolith.

as those of the best big bluestem grown on lowland. The total root-weight was 66.7 grams, compared with 36.6 grams at the other station in (5) Crete silty clay loam and 23.1 grams in (2) Carrington silty clay loam.

Of the soil types on lowland, the total underground materials in (3) Wabash silty clay loam was only half and often much less than half of that in any other soil (Table 2). Roots in the second 6 inches were only half to a third or even a fourth as heavy as in the other soils. Likewise there was much less material at greater depths. This occurred despite the fact that the tops appeared to be equally well developed in all sites. Root systems in (1) Sharpsburg silty clay loam and (4) Judson silt loam were much more equally developed (Figs. 29 and 8). Those in the latter soil with the deeper A horizon and deeper solum were heavier throughout. Decrease in weight with depth was similar in these two soils. Root-weight in the surface soil was slightly greater in (7) Crete silt loam at Carleton than in the two

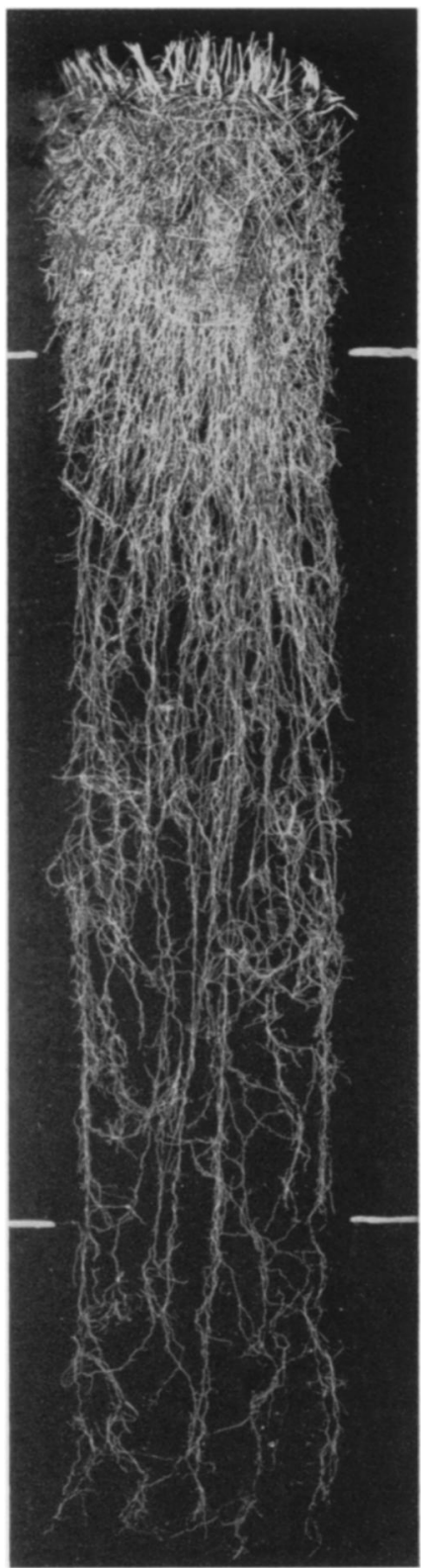

FIG. 29. Root system of big bluestem from a 5-foot monolith of (1) Sharpsburg silty clay loam in a ravine at Lincoln. A few root-ends extended even deeper. 
preceding soils ( 1 and 4 ) at Lincoin, despite the fact that the annual precipitation is an inch less. In this heavy type of silt loam, at the several depths from 6 to 48 inches the roots were $20,44,71$, and 46 percent heavier than in (4) Judson soil near Lincoln. Total root-weight in upland soils, excepting (15) Crete silty clay loam, averaged only 29.9 grams. Root-weight in lowland types averaged 42.5 grams, or 42 percent greater.

The percentage of underground materials in the

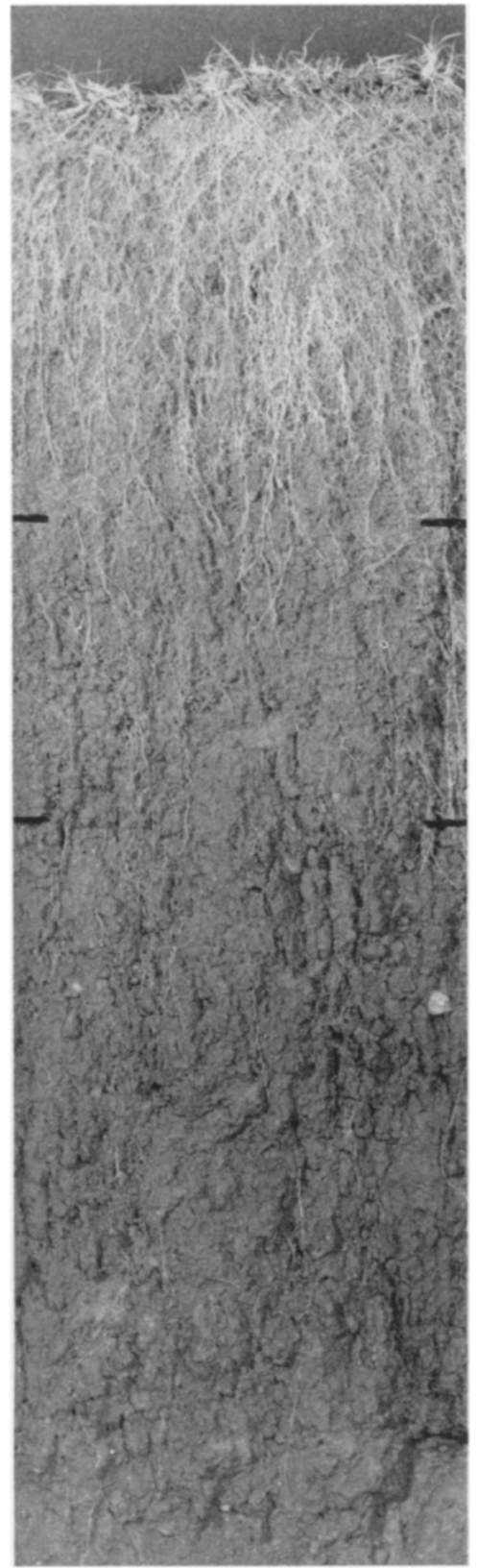

Fig. 30. Monolith of (16) Carrington silty clay loam with the soil partly washed away. Note the concentration of the roots of side-oats grama (Bouteloua curtipendula) (94 percent by weight) in the 12-inch A horizon. Only a few extended deeply. surface 6 inches was somewhat higher in soil types on the upland $(2,5,15)$ where it varied from 75.3 to 80.2. Variation in amount was greater in soil types examined in lowland $(1,3,4,7)$ where 63.5 to 78.7 percent of the underground parts were in the surface 6 inches. Percentage of root-weight in the second 6 inches varied in lowland types from 9.4 to 14.6, and in the second foot from 6.9 to 13.1. It was lower in upland soil types-8.4 to 11.4 and 6.3 to 10.1 percent, respectively.

\section{Little Bluestem}

The greater root development of little bluestem occurred in (7) Crete silt loam at Carleton (Table 2). Although the weight of the upper 6 inches was almost identical with that in (1) Sharpsburg silty clay loam near Lincoln, there were 118, 103, and 108 percent more roots at 6-12, 12-24, and 24-36 inches depth, respectively. Hence the percentage of root distribution at the various depths was also strikingly different. Total root-weights were 52.0. and 59.4 grams.

\section{SWITCHGRASS}

Switchgrass has very coarse roots which may penetrate to depths of 9 to 11 feet (Fig. 1). The roots are much heavier than those of big bluestem from the same trench in (1) Sharpsburg silty clay loam. Moreover, the weight decreases much less rapidly. Roots in the second foot (unlike those of the bluestem) exceeded in amount those in the second 6 inches. Rootweight decreased much less rapidly than in big bluestem in the third and fourth foot. The percentages for this species are not of the entire root system but only of that part above 5 feet. The number of the coarse fibrous roots in the monolith decreased with depth as follows: at 6 inches there were 89 ; at 12 inches, 77 ; then by foot depths, $46,21,16$, and 8 roots, respectively.

\section{Side-oats Grama}

Just as the root-weight of big bluestem was much less in (5) Crete silty clay loam than in (4) Judson silt loam, so too the roots of side-oats grama were lighter in (16) Carrington silty clay loam than in the deep, rich (4) Judson soil (Fig. 30).

16. CARRINGTON SILTY CLAY LOAM, ROLLING PHASE Hori- Depth

zon in. Description

$A_{1} \quad 0.7$ Very dark gray (10YR $3 / 1$ moist) silt loam;

granular; $\mathrm{pH} 6.5$

A 7-12 Dark gray (10YR 4/1 moist) silty clay loam;

$\begin{array}{lll}B_{1} \quad 12-20 & \text { Vranular; } \mathrm{pH} \\ & \text { Very dark gray or }\end{array}$

to $10 \mathrm{YR} 4 / 2$ moist) silty clay logm;

$\mathrm{B}_{2} \quad$ 20-30 Dark grayish brown (2.5 $4 / 2$ moist) silty clay;

The lower inch is calcareous.

Increase in root-weight in (4) Judson soil at the several depths from the surface downward over that in (16) Carrington was 9.07, 0.54, 1.08, and 0.01 grams, respectively. Percentage distribution of weight was about the same in both soil types. Total rootweights were 28.3 and 39.0 grams, respectively. 


\section{KentuCky Bluegrass}

Root-weight of Kentucky bluegrass was much the same and very small in both the upland (2) Carrington silty clay loam and in (3) Wabash silty clay loam of lowland (Table 2). But in (4) Judson silt loam with a 20 -inch $A$ horizon, roots in the first 6 inches were about 230 percent heavier. They averaged 112 percent heavier in the second 6 inches, and 300 percent in the second foot. While roots were confined to the first 2 feet in the first soil type and to 3 in the second, in Judson silt loam some extended into the fourth foot.

\section{Western Wheat Grass}

Amount of roots of western wheat grass in the first 6 inches was about the same (approximately $10 \mathrm{gm}$.) in 3 of the 4 soil types in Table 3 . But it was only 7.2 grams in the most compact soil, (8) Scott silty

TABLE 3. Distribution of root systems at each of the several depths and percentage of roots at each depth.

\begin{tabular}{|c|c|c|c|c|c|c|c|c|c|}
\hline \multirow{2}{*}{$\frac{\text { Spp. }}{A \mathrm{sm}^{1}}$} & \multirow{2}{*}{$\frac{\text { Depth }}{\text { in. }}$} & \multicolumn{2}{|c|}{$\begin{array}{l}5 \text { Crete silty } \\
\text { clay loam }\end{array}$} & \multicolumn{2}{|c|}{$\begin{array}{l}\text { 6 Butler } \\
\text { silt loam }\end{array}$} & \multicolumn{2}{|c|}{$\begin{array}{l}8 \text { Scott silty } \\
\text { clay loam }\end{array}$} & \multicolumn{2}{|c|}{$\begin{array}{c}9 \text { Rendzina } \\
\text { soil }\end{array}$} \\
\hline & & $\begin{array}{l}\text { gm. } \\
9.80\end{array}$ & $\begin{array}{c}\% \\
50.9\end{array}$ & $\begin{array}{c}\text { gm. } \\
10.10\end{array}$ & $\begin{array}{c}\% \\
63.6\end{array}$ & $\begin{array}{l}\text { gm. } \\
7.21\end{array}$ & $\begin{array}{c}\% \\
57.7\end{array}$ & $\begin{array}{l}\mathrm{gm} . \\
9.82\end{array}$ & $\begin{array}{c}\% \\
53.1\end{array}$ \\
\hline & $6-12$ & 2.71 & 14.1 & 1.48 & 9.3 & 1.65 & 13.2 & 3.11 & 16.8 \\
\hline & $12-24$ & 2.60 & 13.5 & 1.99 & 12.5 & 2.58 & 20.7 & 3.15 & 17.0 \\
\hline & $24-36$ & 2.34 & 12.1 & $2.31^{* *}$ & 14.6 & 1.05 & 8.4 & 2.43 & 13.1 \\
\hline & $36-48$ & $1.81^{* *}$ & 9.4 & & & & & & \\
\hline & Total & 19.26 & & 15.88 & & 12.49 & & 18.51 & \\
\hline
\end{tabular}

${ }^{1} \mathrm{~A}$ sm in Agropyron smithii.

clay loam. There was a very striking decrease in rootweight in the second 6 inches in the two soils-(6) Butler and (8) Scott--of the greatest compaction. Also the percentage of decrease in (5) Crete silty clay loam was approximately the same as that in the heavy but less compact (9) Rendzina soil. In the second foot the root-weight was about the same as that in the second 6-inch level in the (5) Crete silty clay loam and (9) Rendzina soil. But it was 34 and 56 percent greater in (6) Butler silt loam and (8) Scott silty clay loam, respectively. Root-weight decreased only a little in the third foot compared with that of the second in (5) Crete silty clay loam, but considerably in (9) Rendzina soil. There was a great decrease in weight in (8) Scott soil, where the root mass was only. 31 inches deep, but in the deeper roots in the (6) Butler type it increased 16 percent over that of the second foot level.

Root-weight below the 0 - to 6 -inch layer was about the same in (5) Crete silty clay loam as in Sharpsburg silty clay loam a half unile distant where there was no elaypan. Here the root-weight was somewhat less than in the Rendzina soil. But the Sharpsburg soil had been covered by two or more inches of dust which adversely affected the original prairie plants and permitted the entrance of wheat grass. Under this condition wheat grass developed extensive rhizomes which, with abundant stem-bases and a good supply of surface roots, increased the weight in the surface 6 inches to more than twice that of either of the other samples.

Percentage of roots in the surface 6 inches was consistently low and often scarceiy more than half of the entire root-weight. It varied from 50.9 to 63.6 , being least in (5) Crete silty clay loam where the roots were longest. The Rendzina soil had the most roots at 6 to 12 inches (16.8 percent). The (8) Scott silty clay loam had the highest percentage of roots (20.7) in the second foot and also the lowest (8.4) in the third foot.

\section{Blue Grama}

There is a striking decrease in the root-weight of blue grama at all levels in (11) Colby silt loam compared with that in (10) Hastings silt loam (Table 4). There is a 25 percent decrease in the weight of underground parts in the surface 6 inches and 28 percent in total root-weight. Weight decreases at 6-12 inches, and at 2,3 , and 4 feet are $48,35,37$, and 24 percent, respectively. But even in the Colby soil there was a much better root development than in the very poor (2) Carrington silty clay loam at Lincoln. There the amount of plant material in the surface 6 inches was 41 percent less, and the entire root-weight only slightly more than half as great as in the Colby soil. The best development of roots was found in (4) Judson silt loam at Lincoln. Here the surface 6 inches contained 31.37 grams of roots compared with 22.55 in the (10) Hastings type and only 16.99 or a little more than half as much in (11) Colby soil. Total root-weights in the three soils were $35.76,28.61$, and 20.60 grams, respectively. But the root-weight in the Hastings type was greater at all depths below 6 inches, and sometimes twice as great as in (4) Judson silt loam. Thus, the increase in total weight of the root system was due to the concentration of material in the surface soil in the Judson type. Even the rootweight in Colby soil was greater in the third and fourth foot.

In the azonal soils of the loess, weight of roots of blue grama between 6 and 36 inches depth was 37 percent less than that of the same species growing in (10) Hastings silt loam. The heavy weight of the first 6 inches was a response to the darker and richer soil held in pedestals under the clumps. This soil was unusually well filled with roots and stem-bases. There was less root-weight in the other grasses which grew 5 or 6 inches lower on the eroding, less fertile soil.

Percentage of roots in loess soils at 0-6 inches was lowest in the best developed soil, (10) Hastings silt loam (78.8). It was higher in (11) Colby silt loam (82.5), and highest in the azonal soil of the loess (88.8). Conversely, the percentage of roots at any greater depth was highest in Hastings soil, less in Colby, but least in the azonal soil. Percentage of roots was the same (about 87.7) at 0-6 inches in (2) Carrington silty clay loam and (4) Judson silt loam at Lincoln, but it was greater at 6-12 inches in Carrington soil. 
TABLE 4. Distribution of root systems at each of the several depths and percentage of roots at each depth.

\begin{tabular}{|c|c|c|c|c|c|c|c|c|c|c|c|c|c|}
\hline \multirow[t]{2}{*}{ Spp. } & \multirow{2}{*}{$\frac{\text { Depth }}{\text { in. }}$} & \multicolumn{2}{|c|}{$\begin{array}{l}10 \text { Hastings } \\
\text { silt loam }\end{array}$} & \multicolumn{2}{|c|}{$\begin{array}{l}11 \text { Colby } \\
\text { silt loam }\end{array}$} & \multicolumn{2}{|c|}{$\begin{array}{l}\text { Azonal } \\
\text { soil }\end{array}$} & \multicolumn{2}{|c|}{$\begin{array}{l}2 \text { Carrington } \\
\text { silty clay loam }\end{array}$} & \multicolumn{2}{|c|}{$\begin{array}{l}4 \text { Judson } \\
\text { silt loam }\end{array}$} & \multicolumn{2}{|c|}{$\begin{array}{c}\text { Azonal soil } \\
\text { (Sand dropseed) }\end{array}$} \\
\hline & & $\mathrm{gm}$. & $\%$ & gm. & $\%$ & gm. & $\%$ & gm. & $\%$ & gm. & $\%$ & gm. & $\%$ \\
\hline \multirow[t]{3}{*}{ B $\mathrm{gr}^{1}$} & \multirow{2}{*}{$\begin{array}{r}0-6 \\
6-12 \\
12-24 \\
24-36 \\
36-48 \\
\text { Total }\end{array}$} & $\begin{array}{r}22.55 \\
2.80 \\
2.05 \\
.92 \\
.29^{*}\end{array}$ & $\begin{array}{r}78.8 \\
9.8 \\
7.2 \\
3.2 \\
\\
1.0\end{array}$ & $\begin{array}{r}16.99 \\
1.47 \\
1.34 \\
.58 \\
\\
.22^{*}\end{array}$ & $\begin{array}{r}82.5 \\
7.1 \\
6.5 \\
2.8 \\
\\
1.1\end{array}$ & $\begin{array}{c}28.75 \\
1.99 \\
1.49 \\
.17^{*}\end{array}$ & $\begin{array}{r}88.8 \\
6.1 \\
4.6 \\
.5\end{array}$ & $\begin{array}{r}10.08 \\
.97 \\
.34 \\
.16\end{array}$ & $\begin{array}{r}87.3 \\
8.4 \\
2.9 \\
1.4\end{array}$ & $\begin{array}{r}31.37 \\
2.39 \\
1.41 \\
.45 \\
\\
.14^{*}\end{array}$ & $\begin{array}{r}87.7 \\
6.7 \\
3.9 \\
1.3 \\
.4\end{array}$ & \multicolumn{2}{|c|}{$\begin{array}{cr}6.32 & 71.1 \\
1.35 & 15.2 \\
.78 & 8.8 \\
.44^{*} & 4.9 \\
\text { (Sporobolus } \\
\text { cryptandrus) }\end{array}$} \\
\hline & & \multicolumn{2}{|l|}{28.61} & \multicolumn{2}{|l|}{20.60} & \multicolumn{2}{|l|}{32.40} & \multicolumn{2}{|l|}{11.55} & \multicolumn{2}{|l|}{35.76} & \multicolumn{2}{|l|}{8.89} \\
\hline & & \multicolumn{2}{|c|}{$\begin{array}{l}12 \text { Holdrege } \\
\text { silt loam }\end{array}$} & \multicolumn{2}{|c|}{$\begin{array}{l}13 \text { Wabash } \\
\text { silt loam (in } \\
\text { Chernozem) }\end{array}$} & \multicolumn{2}{|c|}{$\begin{array}{l}14 \text { Sherman } \\
\text { silt loam }\end{array}$} & \multicolumn{2}{|c|}{ Azonal soil } & & & \multicolumn{2}{|c|}{$\begin{array}{l}\text { Azonal soil } \\
\text { A sm }\end{array}$} \\
\hline \multirow[t]{2}{*}{ B da } & \multirow{2}{*}{$\begin{array}{r}0-6 \\
6-12 \\
12-24 \\
24-36 \\
36-48 \\
\\
\text { Total }\end{array}$} & $\begin{array}{c}15.12 \\
2.47 \\
2.39 \\
.78 \\
.65^{*}\end{array}$ & $\begin{array}{r}70.6 \\
11.5 \\
11.2 \\
3.7 \\
3.0\end{array}$ & $\begin{array}{c}17.09 \\
2.87 \\
2.63 \\
1.28 \\
.67^{*}\end{array}$ & $\begin{array}{r}69.7 \\
11.7 \\
10.7 \\
5.2 \\
2.7\end{array}$ & $\begin{array}{c}18.56 \\
2.97 \\
3.21 \\
1.29 \\
1.00^{*}\end{array}$ & $\begin{array}{r}68.6 \\
11.0 \\
11.9 \\
4.8 \\
3.7\end{array}$ & $\begin{array}{r}7.79 \\
2.04 \\
1.75 \\
.40 \\
.06\end{array}$ & $\begin{array}{r}64.7 \\
17.0 \\
14.5 \\
3.3 \\
.5\end{array}$ & & & $\begin{array}{l}6.37 \\
1.36 \\
2.09 \\
1.27 \\
.23^{*}\end{array}$ & $\begin{array}{r}56.3 \\
12.0 \\
18.5 \\
11.2 \\
2.0\end{array}$ \\
\hline & & 21.41 & & 24.54 & & 27.03 & & 12.04 & & & & 11.32 & \\
\hline
\end{tabular}

${ }^{1} \mathrm{~B} \mathrm{gr}$ is Bouteloua gracilis and B da, Buchloe dactyloides.

\section{Buffalo Grass}

Weight of roots of Buchloe dactyloides was greater at all depths in (13) Wabash silt loam, where there was a fill of 12 inches, than on the higher land where (12) Holdrege silt loam was sampled (Table 4). The increased weight was rather uniformly distributed throughout the root-length. Total root-weights were 24.54 and 21.41 grams, respectively. In (14) Sherman silt loam, with a buried profile where the sample was taken, total root-weight increased to 27.03 grams. This increased weight was only partly in the surface soil. At any depth the weight of roots exceeded that from either of the preceding monoliths. The greater weight in the second-foot level than at 6-12 inches is peculiar to this sample only and seems to reflect more favorable conditions for growth in the A horizon of the buried profile.

Weight of roots in the azonal soil varied from 12.04 grams in buffalo grass to 11.32 in western wheat grass, and was even less (8.89 grams) in sand dropseed. This is only half of the average weight of roots of the first two grasses where they grew in mature loess soils.

Percentage distribution of weight was remarkably uniform in the three soil types. Variations at 0-6 inches were from 68.6 to 70.6. They were even less in the second and third layers, but the (14) Sherman silt loam had the highest percentage of roots in the deeper soil (24 to 48 inches). Percentage of total root-weight in the azonal soil was much less (64.7) at 0-6 inches, but greater at 6-12 inches and in the second foot. A somewhat similar percentage distribution maintained in sand dropseed and in western wheat grass in the eroded soil. The greater weight of the second foot of wheat grass roots than the second 6 inches has been ascertained also in Sharpsburg silty clay loam.

\section{PERCENTAGE OF ROOTS IN EACH MAJOR SOIL HORIZON}

The percentage of the root system of big bluestem which occurred in the $A$ horizon in the several soil types varied almost directly with its depth. As shown in Table 5 , these percentages are in soil type (2) $0-7$ inches, 78.0 ; (7) $0-11$ inches, 75.9 ; $(5,1$, and 15) $0-12$ inches, 88.4 tc 88.6 ; (3) $0-13$ inches, 88.9 ; and (4) 0-20 inches, 89.8. Conversely, the percentag of roots in the B horizon decreased from soils with shallow A horizons to soils with deep A horizons. In the same sequence, the percentages are $18.3,21.9,11.5$ to $7.2,10.2$, and 9.7. Roots in the $\mathrm{C}$ horizon decreased in the same general order-3.7, $2.2,0.6$ to $4.2,0.9$, and 0.5 .

Proportion of the root-weight of little bluestem in the A horizon also varied with its depth, 84.6 percent where it was 11 inches deep (7), but 91.1 where it was an inch deeper (1). The deep B horizons contained nearly all of the remainder; (7) 11-36 inches, 14.3 percent and (1) 12-48 inches, 8.7 percent.

Switchgrass had 76.7 percent of its roots (to 5 feet) in the 12-inch A horizon, 21.2 in the 3-foot thick B horizon, but only 2.1 in horizon D.

Side-oats grama had 97.5 percent of the root-weight in the 20-inch thick A horizon of (4) Judson silt loam and the remainder in the thick $B$ horizon. But in (16) Carrington soil the 12-inch A horizon contained 93.9 percent of the roots. The rest were distributed in the 8-inch $\mathrm{B}$ horizon (3.1 percent) and (3.0 percent) in the $C$ layer.

Kentucky bluegrass in (2) Carrington silty slay 
TABLE 5. Distribution of root systems of grasses in the several soil horizons. The depth of the A and B horizons and depth of the monolith in the $\mathrm{C}$ horizon are indicated in inches.

\begin{tabular}{|c|c|c|c|c|c|c|c|c|c|c|c|c|c|c|c|c|c|c|}
\hline \multirow[t]{2}{*}{ Spp. } & \multirow[t]{2}{*}{ H. } & \multicolumn{3}{|c|}{$\begin{array}{l}1 \text { Sharpsburg } \\
\text { silty clay loam }\end{array}$} & \multicolumn{2}{|l|}{$\begin{array}{l}4 \text { Judson } \\
\text { silt loam }\end{array}$} & \multicolumn{3}{|c|}{$\begin{array}{l}5 \text { Crete silty } \\
\text { clay loam }\end{array}$} & \multicolumn{3}{|c|}{$\begin{array}{l}2 \text { Carrington } \\
\text { silty clay loam }\end{array}$} & \multicolumn{3}{|c|}{$\begin{array}{l}3 \text { Wabash silty } \\
\text { clay loam }\end{array}$} & \multicolumn{3}{|c|}{$\begin{array}{l}7 \text { Crete silt } \\
\text { loam }\end{array}$} \\
\hline & & in. & gm. & $\%$ & in. $\mathrm{gm}$. & $\%$ & in. & gm. & $\%$ & in. & gm. & $\%$ & in. & gm. & $\%$ & in. & gm. & $\%$ \\
\hline $\mathrm{A} \mathrm{fu}$ & $\begin{array}{l}\mathbf{A} \\
\mathbf{B} \\
\mathbf{C}\end{array}$ & $\begin{array}{l}12 \\
48 \\
60\end{array}$ & $\begin{array}{r}37.84 \\
4.96 \\
.27^{*}\end{array}$ & $\begin{array}{r}87.9 \\
11.5 \\
.6\end{array}$ & $\begin{array}{cc}20 & 44.17 \\
53 & 4.79 \\
60 & .25 *\end{array}$ & $\begin{array}{r}89.8 \\
9.7 \\
.5\end{array}$ & $\begin{array}{l}12 \\
28 \\
48\end{array}$ & $\begin{array}{c}32.42 \\
3.07 \\
1.18 *\end{array}$ & $\begin{array}{r}88.4 \\
8.4 \\
3.2\end{array}$ & $\begin{array}{r}7 \\
22 \\
48\end{array}$ & $\begin{array}{r}18.08 \\
4.24 \\
.85\end{array}$ & $\begin{array}{r}78.0 \\
18.3 \\
3.7\end{array}$ & $\begin{array}{l}13 \\
36 \\
48\end{array}$ & $\begin{array}{r}19.03 \\
2.18 \\
.19\end{array}$ & $\begin{array}{r}88.9 \\
10.2 \\
.9\end{array}$ & $\begin{array}{l}11 \\
36 \\
48\end{array}$ & $\begin{array}{c}42.74 \\
12.34 \\
1.24^{*}\end{array}$ & $\begin{array}{r}75.9 \\
21.9 \\
2.2\end{array}$ \\
\hline A sc & $\begin{array}{l}\mathbf{A} \\
\mathbf{B} \\
\mathbf{C}\end{array}$ & $\begin{array}{l}12 \\
48 \\
60\end{array}$ & $\begin{array}{r}47.34 \\
4.54 \\
.12\end{array}$ & $\begin{array}{r}91.1 \\
8.7 \\
.2\end{array}$ & $\begin{array}{l}\mathrm{P} \text { vi } \\
1 \text { Sharpsbur } \\
\text { silty clay loa }\end{array}$ & & $\begin{array}{l}12 \\
48 \\
60\end{array}$ & $\begin{array}{l}43.88 \\
12.10^{* *} \\
1.20^{* *}\end{array}$ & $\begin{array}{r}76.7 \\
21.2 \\
2.1\end{array}$ & & $\begin{array}{l}\text { Crete si } \\
\text { loam }\end{array}$ & & $\begin{array}{l}12 \\
27 \\
60\end{array}$ & $\begin{array}{c}59.12 \\
4.82 \\
2.81^{*}\end{array}$ & \begin{tabular}{r|}
88.6 \\
7.2 \\
4.2
\end{tabular} & $\begin{array}{l}11 \\
36 \\
48\end{array}$ & $\begin{array}{r}50.28 \\
8.50 \\
.62\end{array}$ & $\begin{array}{r}84.6 \\
14.3 \\
1.1\end{array}$ \\
\hline $\mathrm{B} \mathrm{cu}$ & $\begin{array}{l}\text { A } \\
\text { B } \\
\text { C }\end{array}$ & & & & $\begin{array}{rr}20 & 38.08 \\
53 & .96\end{array}$ & $\begin{array}{r}97.5 \\
2.5\end{array}$ & & & & & & & $\begin{array}{l}16( \\
\text { silty } \\
\text { rolli }\end{array}$ & $\begin{array}{l}\text { Carringt } \\
\text { clay lo } \\
\text { ng phas }\end{array}$ & $\begin{array}{l}\text { on } \\
\text { am; } \\
\text { e }\end{array}$ & $\begin{array}{l}12 \\
20 \\
41\end{array}$ & $\begin{array}{r}26.60 \\
.89 \\
.85\end{array}$ & $\begin{array}{r}93.9 \\
3.1 \\
3.0\end{array}$ \\
\hline $\mathrm{P}$ pr & $\begin{array}{l}\mathbf{A} \\
\mathbf{B}\end{array}$ & & & & $\begin{array}{rr}20 & 26.79 \\
53 & .87\end{array}$ & $\begin{array}{r}96.9 \\
3.1\end{array}$ & & & & $\begin{array}{r}7 \\
22\end{array}$ & $\begin{array}{l}7.26 \\
1.63\end{array}$ & $\begin{array}{l}81.7 \\
18.3\end{array}$ & $\begin{array}{l}13 \\
36\end{array}$ & $\begin{array}{r}7.79 \\
.65\end{array}$ & $\begin{array}{r}92.3 \\
7.7\end{array}$ & & & \\
\hline
\end{tabular}

loam had 81.7 percent of its roots in the 7 -inch thick $A$ horizon and the remainder in the $B$ (7-22 in.) horizon. Where the A horizon was 13 inches deep (3, Wabash silty clay loam) 92.3 percent of the roots were in this layer and the remainder in the $B$ horizon (13-36 in.). But as the $A$ horizon became deeper (0-20 in. in 4, Judson silt loam) the percentage of roots in it increased to 96.9 , some of the remaining roots penetrating the thick $B$ layer (20-53 in.) to a depth of 4 feet.

Western wheat grass in the shallow A horizon (0-5 in.) of (8) Scott silty clay loam had the smallest percentage (55.2) of root materials (Table 6). The thickest A horizon (0-12 in.) in (5) Crete silty clay loam contained slightly less (65.0) than that of the shallower topsoil (7.5 in.) of the (6) Butler type. The B horizon of the Scott soil (5-41 in.) contained 44.8 percent of the entire root system, but that of the Butler (7.5-28 in.) only 24.7 percent, the remaining 8.1 percent occurring in the $\mathrm{C}$ horizon. Root distribution in Crete soil was somewhat similar to that in the Butler; the percentage in the $B$ horizon (12-28 in.) was 18.4 and in the $\mathrm{C}, 16.6$. Root distribution in the Rendzina was intermediate to that in the Scott and Butler soils. Percentage of roots in the B horizon was far greater than in any species of grass in the preceding, less compacted soils.

Percentage of roots of blue grama in the A horizon increased directly with the depth of this layer (Table 6). It was practically the same, however, in the

TABLE 6. Distribution of root systems of grasses in the several soil horizons. The depth of the A and B horizons and depth of the monolith in the $C$ horizon are indicated in inches.

\begin{tabular}{|c|c|c|c|c|c|c|c|c|c|c|c|c|c|}
\hline \multirow[t]{2}{*}{ Spp. } & \multirow[t]{2}{*}{ H. } & \multicolumn{3}{|c|}{5 Crete silty clay loam } & \multicolumn{3}{|c|}{6 Butler silt loam } & \multicolumn{3}{|c|}{8 Scott silty clay loam } & \multicolumn{3}{|c|}{9 Rendzina soil } \\
\hline & & in. & gm. & $\%$ & in. & gm. & $\%$ & in. & gm. & $\%$ & in. & gm. & $\%$ \\
\hline \multirow[t]{2}{*}{ A sm } & $\begin{array}{l}\text { A } \\
\mathbf{B} \\
\mathbf{C}\end{array}$ & $\begin{array}{l}12 \\
28 \\
48\end{array}$ & $\begin{array}{l}12.51 \\
3.55 \\
3.20^{* *}\end{array}$ & $\begin{array}{l}65.0 \\
18.4 \\
16.6\end{array}$ & $\begin{array}{r}7.5 \\
28.0 \\
36.0\end{array}$ & $\begin{array}{c}10.67 \\
3.93 \\
1.28\end{array}$ & $\begin{array}{r}67.2 \\
24.7 \\
8.1\end{array}$ & $\begin{array}{r}5 \\
41 \\
48\end{array}$ & $\begin{array}{l}6.89 \\
5.60\end{array}$ & $\begin{array}{l}55.2 \\
44.8\end{array}$ & $\begin{array}{l}10 \\
27 \\
36\end{array}$ & $\begin{array}{r}10.81 \\
5.93 \\
1.77\end{array}$ & $\begin{array}{r}58.4 \\
32.0 \\
9.6\end{array}$ \\
\hline & & \multicolumn{3}{|c|}{$\begin{array}{l}10 \text { Hastings } \\
\text { silt loam }\end{array}$} & \multicolumn{3}{|c|}{$\begin{array}{l}11 \text { Colby } \\
\text { silt loam }\end{array}$} & \multicolumn{3}{|c|}{$\begin{array}{l}2 \text { Carrington } \\
\text { silty clay loam }\end{array}$} & \multicolumn{3}{|c|}{$\begin{array}{l}4 \text { Judson } \\
\text { silt loam }\end{array}$} \\
\hline \multirow[t]{2}{*}{$\mathbf{B}$ gr } & $\begin{array}{l}\mathbf{A} \\
\mathbf{B} \\
\mathbf{C}\end{array}$ & $\begin{array}{l}15 \\
35 \\
48\end{array}$ & $\begin{array}{c}26.04 \\
2.23 \\
.34^{*}\end{array}$ & $\begin{array}{r}91.0 \\
7.8 \\
1.2\end{array}$ & $\begin{array}{l}12 \\
20 \\
48\end{array}$ & $\begin{array}{c}18.46 \\
1.09 \\
1.05^{*}\end{array}$ & $\begin{array}{r}89.6 \\
5.3 \\
5.1\end{array}$ & $\begin{array}{r}7 \\
22 \\
36\end{array}$ & $\begin{array}{r}10.30 \\
1.05 \\
.20\end{array}$ & $\begin{array}{r}89.2 \\
9.1 \\
1.7\end{array}$ & $\begin{array}{l}20 \\
53\end{array}$ & $\begin{array}{r}34.86 \\
.90\end{array}$ & $\begin{array}{r}97.5 \\
2.5\end{array}$ \\
\hline & & \multicolumn{3}{|c|}{$\begin{array}{l}12 \text { Holdrege } \\
\text { silt loam }\end{array}$} & & & \multicolumn{3}{|c|}{$\begin{array}{l}13 \text { Wabash silt loam } \\
\text { (in Chernozem) }\end{array}$} & & \multicolumn{3}{|c|}{$\begin{array}{l}14 \text { Sherman } \\
\text { silt loam }\end{array}$} \\
\hline B da & $\begin{array}{l}\mathbf{A} \\
\mathbf{B} \\
\mathbf{C}\end{array}$ & $\begin{array}{l}12 \\
36 \\
48\end{array}$ & $\begin{array}{r}17.59 \\
3.17 \\
.65^{*}\end{array}$ & $\begin{array}{r}82.2 \\
14.8 \\
3.0\end{array}$ & $\begin{array}{l}\text { Fill } \\
\text { A } \\
\text { C }\end{array}$ & & $\begin{array}{l}12 \\
36 \\
48\end{array}$ & $\begin{array}{l}96 \\
91 \\
67^{*}\end{array}$ & $\begin{array}{r}81.4 \\
15.9 \\
2.7\end{array}$ & $\begin{array}{l}\mathbf{A} \\
\text { Old A } \\
B_{1}\end{array}$ & $\begin{array}{l}17 \\
29 \\
36\end{array}$ & $\begin{array}{c}23.31 \\
2.18 \\
.54^{*}\end{array}$ & $\begin{array}{r}89.5 \\
8.4 \\
2.1\end{array}$ \\
\hline
\end{tabular}


12-inch thick horizon in (11) Colby silt loam and in the 7-inch layer of (2) Carrington silt loam. In both the amount was about 89.5 percent. In the surface 15 inches of (10) Hastings silt loam it increased slightly (to 91.0 percent) but the 20 -inch-deep A horizon of (4) Judson silt loam contained 97.5 percent of the root-weight. From the 8-inch thick B horizon of (11) Colby silt loam, 5.3 percent of the root-weight was recovered. The 15 -inch horizon of (2) Carrington silty clay loam had 9.1 percent. Conversely, the 20-inch thick B horizon of (10) Hastings silt loam had only 7.8 percent of root-weight, while the 33-inch B horizon of (4) Judson silt loam contained only 2.5 percent.

The percentages of roots of buffalo grass in the $A$, $\mathrm{B}$, and $\mathrm{C}$ horizons are shown in Table 6 for (12) Holdrege silt loam only. The (14) Sherman silt loam contains a buried soil; the Wabash silt loam has a 12inch fill. Regardless of these, the upper layer in each soil which is 12 inches thick contains about 82 percent of the root system; the 17-inch A horizon 89.5. Likewise, the deeper second layers have more roots (14.8 to 15.9 percent) than the shallower one in (14) Sherman silt loam which has 8.4 percent.

\section{DISCUSSION}

The well drained and well developed "zonal" soils of the grasslands of Nebraska and Kansas comprise chiefly three great groups-the black "Prairie soils" of the humid grasslands, the "Chernozems" ("black earths") of the subhumid grasslands, and the "Chestnut" (Dark-Brown) soils of the semiarid grasslands. The still lighter colored "Brown soils" occupy only a small total area in southwestern Kansas. Associated with each of the zonal soils are other soils, some young ones with only the beginnings of soil development (azonal soils), some with excessively developed claypan subsoils (Planosols), and others poorly drained and marshy but without claypans (Wiesenboden) of the intrazonal order.

Samples of zonal soils taken near Lincoln are from the boundary between the zones of Prairie and Chernozem soils. Prairie soils typically are nearly black, moderately to strongly acid in reaction, and without an accumulation of calcium (lime) carbonate in the subsoil. The Chernozems are similar to the Prairie soils in color but are nearly neutral in reaction and typically have an accumulation of lime carbonate in their subsoils. Chestnut soils are somewhat lighter-colored and lower in organic matter than the Chernozems.

Soils generally grade into one another without sharp breaks. Hence, some of the samples described in this paper are intermediate between types rather than representing the mode for each type. This caused some difficulty in classifying some of the soils.

Roots were not separated in the surface soil principally because the rhizomes and stem-bases function as roots in the processes of modifying soil structure, adding organic matter to the soil, and in preventing erosion. They are produced at about the same general rate as roots and are no more nor no less resistant to decay than are the absorbing organs (Weaver \& Zink 1946; Weaver 1947). Soil scientists were in agreement with the authors in their decision not to exclude the underground stems and stem-bases from the materials in the topsoil.

It is of interest, however, that the roots alone often constitute the minor part of the weight of underground materials in the surface soil. In one determination on about 3 square feet of each of three species, the roots of big bluestem composed 49.5 percent of the weight of plant materials in the surface 4 inches of soil. Likewise, they composed only 28 percent in both little bluestem and blue grama. Despite this, in big bluestem 43 percent of the entire root system by weight was found in the surface 4 inches of sod after three growing seasons. In little bluestem it was 36 percent, and in blue grama 49. The first foot of soil contained 78 percent of the roots of big bluestem, 69 percent of little bluestem, and 80 percent of the roots of blue grama (Weaver \& Zink 1946).

The 33 monoliths examined were taken in three general areas. One was in the vicinity of Lincoln near the Prairie soil-Chernozem border in eastern Nebraska. A second was 65 to 125 miles southwestward in the Chernozem soil area at Carleton and Bruning, Nebraska, and Belleville, Kansas. The loess hills near Kearney in central Nebraska, also in the general Chernozem soil area, was the source of the third group.

Each monolith was taken for some special reason. The study of big bluestem in many different soils was chiefly due to the fact that since the death by drought of more than 90 percent of little bluestem in eastern Nebraska, big bluestem is the most widely represented predrought dominant of true prairie. An early excavation of both these species in the soil of a single trench (1, Sharpsburg silty clay loam) was for the purpose of a careful comparison of the two root systems.

Further study of big bluestem revealed a reason for its spreading into most soil types of upland as well as lowland. The coarse, deep, but comparatively poorly branched root system typical of deep, well watered, and fertile soils as (7) Crete silt loam (thick solum) and (4) Judson silt loam was greatly modified in less mesic sites. Here the main roots were usually much finer and much better branched, and somewhat more of the root-weight occurred near the surface of the soil. These adjustments of this plastic root system help explain the wide postdrought distribution of this grass, sometimes in somewhat droughty soils like (2) Carrington silty clay loam. But where native vegetation on uplands was kept thinned by repeated deposits of dust (15, Crete silty clay loam), and there was much available space from which to obtain both water and nutrients, a deeper, coarser root system was again maintained.

The root system of little bluestem was much better developed in (7) Crete silt loam with a thick solum than in a semiupland site (1, Sharpsburg silty clay loam). The root system from a third monolith of an 


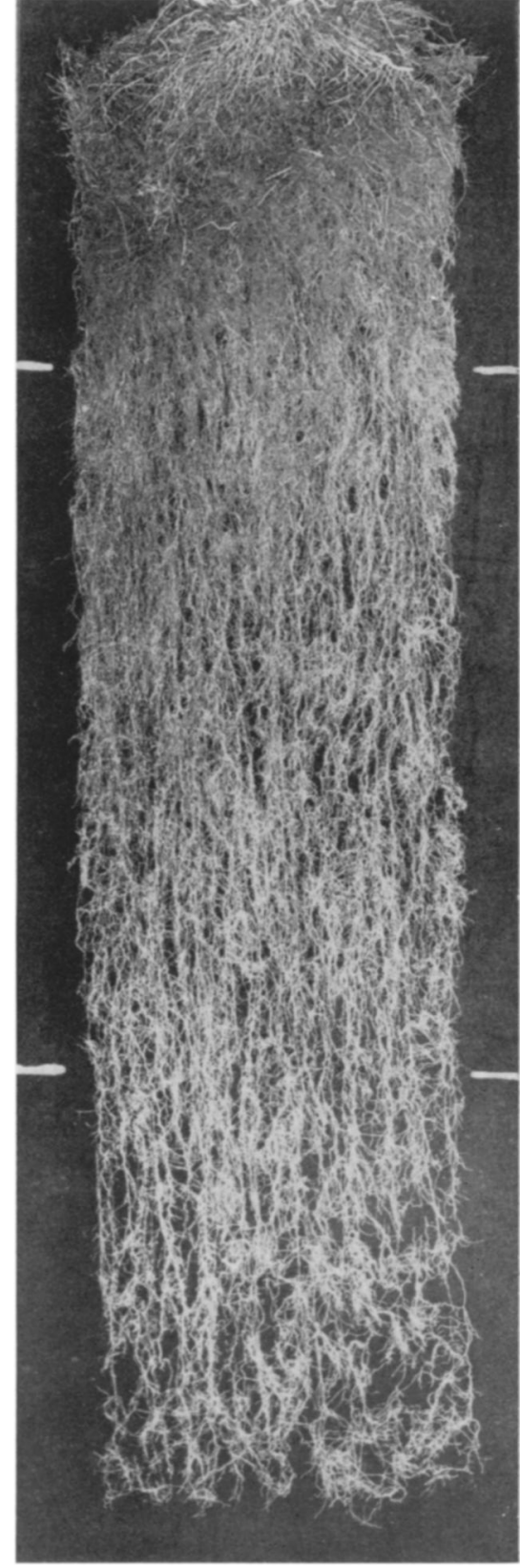

FiG. 31. Root system of little bluestem from a 4-foot monolith of Carrington silty clay loam. The A horizon was 12 inches thick. This dense, well-branched root system is very uniform in appearance throughout the $B$ horizon (12 to 34 in.). Many roots extended more than a foot below the solum into the parent material.

upland soil (Carrington silty clay loam), not weighed but mounted for class use, had finer but more profusely branched roots than either of the preceding (compare Fig. 31 with 1 and 15). Similar differences were found in the roots of blue grama and Kentucky bluegrass (Table 2).

The great invasion of western wheat grass and its almost complete replacement of other native vegeta- tion over vast areas of prairie and pasture occurred during the cycle of drought (1934-40). The difficulty of its replacement by other species and consequently its persistence in many places in pure stands is a problem of great economic importance. Wheat grass lacks the dense mass of fine leaves characteristic of bluestems and most other prairie grasses. Hence, it permits the beating rains to destroy the soft crumblike soil aggregates at the surface. Rapid penetration of water is prevented by puddling of surface soil. Consequently the soil absorbs less of the precipitation, runoff is promoted, and erosion is accelerated. As a result, conditions of drought have been maintained for a long period of time.

Before the drought, western wheat grass was confined largely to certain clay soils and soils with claypans. It now covers many "slick spots" as well as other soils. The root distribution was studied particularly to obtain further information on this problem. It appears now that replacement of wheat grass by more mesic species is occurring gradually on soils that have not degenerated into Planosols, but that wheat grass may persist for a long time or indefinitely where heavy claypans are present.

In the loess hills of central Nebraska a chief type of natural vegetation is short grass. Under grazing this community becomes more and more widely spread and finally excludes all others. Studies on yield and consumption of blue grama and buffalo grass prompted a study of the root system in the various soil types from the light-colored (11) Colby silt loam to the darker (13) Wabash silt loam in the valleys. The effect of extensive erosion of these relatively unstable soils, brought about by overuse of the range or plowing and abandoning the land, was shown everywhere. Root distribution in the resulting azonal soils aided in understanding the decreased yield and the slow development of a new cover of vegetation. This required a number of monoliths besides those in the short grass.

The problem of a buried soil profile and its effect upon root distribution is intriguing. Such profiles occur in many places and often account for abrupt differences in the composition of the vegetation and are definitely known to affect root habits within the species as well. For example, the Loveland loess accumulated rapidly as a thick cover over the region in central Nebraska now known as the Loess Hills and Plains. Its deposition was followed by a relatively long period of weathering and soil development. Thus a dark surface soil with a reddish brown clayey subsoil was developed at the top of the Loveland. This differs greatly in texture and permeability not only from the coarse silt of the middle and lower parts of this loess but also from the lower and middle parts of the yellowish to whitish Peorian loess which was deposited upon a rough topography during later periods of loess accumulation. Under these conditions water from precipitation tends to move downward, 30 to 40 feet where the layer of Peorian loess is thick, with comparative ease until the Peorian- 
Loveland contact is reached. Here permeability is greatly restricted and the groundwater movement is directed laterally toward the valley or canyon sides where it is discharged as seeps or springs. Thus grasses growing on a hillside in soil originating from a thin layer of Peorian loess may extend their roots into the topsoil of the Loveland. Deeper roots, as those of Liatris punctata, Rosa pratincola, or Lygodesmia juncea, may make these contacts at a depth of 10 to 20 feet. The differences in soil compaction, water content, and amount of clay and nutrients, often cause marked differences in root development. Such differences were shown in a small degree by buffalo grass in (14) Sherman silt loam. (See also the grass roots in (2) Carrington silty clay loam.)

Future studies should include chemical analyses of the soil especially in the subhorizons where marked differences in root numbers or branching occur. Water relations and air content of soils at various depths during the growing season, especially in claypan soils, should be ascertained. Perhaps the shorter-lived roots of annual cereal crops react quite differently than those of perennial grasses and tend to develop mostly on the surfaces of the prisms and blocky soil structures. A monolith with a large portion of a well established root system lends itself readily to experimentation on the absorbing capabilities of roots at various levels. When the monolith is taken in an appropriate box, nutrients may be added at any level. Or after the soil and plants have dried and the tops are dead, the degree of new growth from water applied directly at different levels yields information on amount of absorption at different depths. Preliminary studies on the growth of grasses when watered at various depths show that roots absorbing water at a depth of 2 or even 3.5 feet only, produced only a small amount of tops. The amount of absorption decreased directly with the depth at which the soil was supplied with water (Nedrow 1937).

This method is applicable in the study of the soilroot relationships not only of introduced grasses, weedy grasses, and cultivated cereals, but also to many non-grassy species of native and crop plants. The monoliths might be widened and deepened if necessary. The general spreading and depth of roots in all the species here recorded may be found in the early literature already cited.

\section{SUMMARY}

A new method has been devised for obtaining representative samples of entire root systems. It permits the studying of the intimate relations of roots and soils, and of measuring root production quantitatively at various soil levels.

Descriptions have been made of each of 16 soil types from which 11 species of grasses were taken. They include not only the depths of the main soil horizons and the minor subdivisions of each, but also the color, texture, structure, consistence and $\mathrm{pH}$ of soil in each subdivision. Some interrelationships of the soil types are given.

Monoliths of soil 12 inches wide, 3 inches thick, and from 3 to 5 feet in depth were taken from the walls of trenches made in selected pure stands of each species. The 33 monoliths examined were taken in three general areas. One was in the vicinity of Lincoln near the Prairie soil-Chernozem boundary in eastern Nebraska. Another was 65 to 125 miles southwestward in the Chernozem soil area, and the third in the loess hills near Kearney in central Nebraska where both Chernozem and Dark-Brown soils are found.

Roots were obtained from the monolith by a sytsem of soaking and gentle washing. A special technique was used in mounting; lighting for photographing was by electro-flash units, and sectioning was done in such a manner as to obtain the oven-dry weight for each 6 inches or foot in depth as well as for each major horizon.

Kentucky bluegrass (Poa pratensis), blue grama (Bouteloua gracilis), and big bluestem (Andropogon furcatus) were studied in a shallow, compact Carrington silty clay loam, in a young, alluvial Wabash silty clay loam, and in deep, well drained Judson silt loam developed in silty colluvium, a soil type lying between upland soils and alluvial bottomlands. The roots of bluegrass increased in depth from 22 to 36 inches and then to 48 from Carrington to Judson soil type. The bulk of the roots ( 82 percent) were confined to the shallow A horizon (0-7 in.) in the first type. In the second, the massive portion of the root system was slightly less dense but extended more deeply. In Judson soil the deep A horizon (0-20 in.) was filled with a great mass of roots with a total weight more than three times as great as either of the preceding root systems.

Blue grama developed 89 percent of its roots in the shallow A horizon of the Carrington silty clay loam. In the Judson silt loam a great mass of roots grew in the A horizon and extended through the $\mathrm{B}_{1}$ (20-31 in.) as well. The ratio of the weight of the first root system to the second was 1 to 3 .

The normally deep-rooted big bluestem extended only a few of its roots beyond 3 feet in depth in both the Carrington and Wabash soil types. Chief differences were a denser mat of roots in the A horizon and much finer roots with more numerous branches in Carrington soil. The mass of roots penetrated only half as deeply here as in Wabash soil. The dense root system in the A horizon of the Judson soil weighed approximately twice as much as either of the preceding entire root systems. Root depth was 5 feet.

Five monoliths were taken, all with western wheat grass (Agropyron smithii), from intrazonal soils in Prairie and Chernozem areas. The claypan (B horizon) in Crete silty clay loam at Lincoln was at 12-28 inches depth. Roots were abundant, well branched, and easily washed from the mellow, granular topsoil. The blocky prismatic, compacted soil of the B layer was less well penetrated by roots; it was removed with difficulty. Greatest branching and a large proportion of the root system occurred below 28 inches in the mellow, loessal parent material of the $\mathrm{C}$ horizon. 
Butler silt loam in the Chernozem area had a 7.5inch A horizon. The dark colored B horizon (7.5-28 in.) of blocky clay was a barrier to the penetration of both water and roots, at least when dry, except the deep cracks caused by shrinkage during drought. Only in the lower third of the B and especially in the yellowish, less compact $\mathrm{C}$ horizon was branching of roots pronounced. Weight of roots in the 13 inches below the level where good branching began was 36.5 percent greater than in the 13 inches above. This deeper soil apparently received much water through the cracks in the claypan.

Fifty feet distant from the trench in Butler soil, roots of the bluestems were examined in monoliths of Crete silt loam with a thick solum. Here root distribution was quite unlike that of wheat grass. Roots were much heavier, their weight decreased uniformly with depth, and they occupied the soil, which was far more uniform in structure, to a depth of 4 to 4.5 feet.

A distribution of roots similar to that in Butler soil occurred in Scott silty clay loam, only here the claypan at 5 to 41 inches was thicker and even more compact. No roots extended beyond 31 inches, except in deep cracks. Roots penetrated the prisms and blocks of soil (probably when these were moist) which were so hard when dry that they could scarcely be erushed with a sledge hammer. Many branches were short, flattened, and thickened.

A 38-inch deep, well drained Rendzina soil with a clayey subsoil overlaid hard, unweathered limestone. Here the distribution of rocts was similar to that in soils with a claypan; 42 percent were below the 10inch A horizon.

Blue grama was examined in a monolith taken on a loess hill near Kearney in a mature soil, Hastings silt loam. Roots were especially abundant in the A horizon (0-15 in.) but fewer at greater depths. They continued to branch profusely to 4 feet; a few were 5 feet long. But in the immature Colby silt loam in a similar site, although the roots were concentrated in the 12-inch A horizon, even this layer was relatively poorly occupied. Root-weight was 25 percent less at 0-6 inches depth here than in Hastings soil. Differences at greater depths were even more marked, but depth of penetration was 5.5 feet.

Buffalo grass (Buchloe dactyloides) in a mature loess soil, Holdrege silt loam, on upland was remarkably uniform in decrease of roots with depth; some roots were 6 feet long. In a flat-bottomed valley of Wabash silt loam the roots were heavier at all depths than in Holdrege soil; some were 6.5 feet deep.

In Sherman silt loam on a hillside where there was a buried soil profile at 17 inches depth, the root system of buffalo grass was somewhat better developed at all levels than either of the preceding. Unlike roots in the preceding soil types in loess, which decreaser? in weight with depth, here there was an increase in weight in the second foot over that in the second 6 inches, probably due to the buried A horizon of an old soil.

In much eroded loess where the entire solum had been removed, development of several grasses was only about half normal. Root systems of buffalo grass, western wheat grass, and sand dropseed (Sporobolus cryptandrus) weighed only about half as much as roots of the same species in mature Holdrege silt loam. The roct mass was concentrated in the upper 12 inches; a 2- to 3-inch $A_{1}$ horizon was developing.

Weight of roots of big bluestem at 0-6 inches depth ranged from 16.8 to 53.5 grams in the different types of soil. These amounts were 79 and 80 percent, respectively, of the total root weight. In the second 6 inches the range was from 2.0 to 8.2 grams. Roots in the second foot always weighed less than those in the second 6 inches, just as root-weight in the third foot was always less than that in the second. No plant produced more than 1.24 grams of roots in the fourth foot.

Percentage of roots of big bluestem in the surface 6 inches ranged from 75.3 to 80.2 in the three soil types of upland and much less (63.5 to 78.7) in four soil types on lowland. Percentage of roots in the second 6 inches and in the second foot was lower in upland types.

Total root-weight and distribution of root-weight of little bluestem (Andropogon scoparius) were not greatly different from those of big bluestem, except the roots were heavier in the surface soil and the root system was 12 to 18 inches shallower. Total root weight of side-oats grama (Bouteloua curtipendula) varied from 28.3 grams in Carrington silty clay loam to 39.0 in Judson silt loam but percentage distribution of weight was about the same in both soil types.

Roots of bluegrass varied in weight in the surface 6 inches from 6.78 grams in Carrington silty clay loam to 22.04 in Judson silt loam. Total root-weights were 8.89 and 27.66 grams, respectively.

Weight of roots of western wheat grass was low, 7.21 to 10.10 grams. in the surface 6 inches of all the claypan soils. Percentage of root-weight here was also consistently low and often scarcely more than half that of the entire root-weight. There was a striking decrease in weight (to 1.48 and 1.65 grams, respectively) in the second 6 inches in the two soil types (Butler and Scott) of greatest compaction. Weight increased 16 percent in the third foot of Butler soil over that of the second foot.

Roots of blue grama in the upper 6 inches of Colby silt loam were 25 percent lighter, and the total rootweight was 28 percent less than in Hastings silt loam. Likewise root-weight in Carrington silt loam at Lincoln was 41 percent less in the surface 6 inches and total root-weight was only about half that in Colby soil. The heaviest root system was in Judson silt loam, 35.76 grams, compared with 28.61 in Hastings soil, 20.60 in Colby, and 11.55 in Carrington.

Greater root-weight of buffalo grass at all depths was obtained in Wabash silt loam (at Kearney) than in the higher land where Holdrege silt loam was sampled. Total root-weights were 24.54 and 21.41 grams. But in Sherman silt loam, root-weight exceeded that from either of the preceding monoliths at all depths.

Root-weights of buffalo grass and western wheat 
grass in azonal soils of loess were reduced to 12.04 and 11.32 grams respectively, which was about half their weights in mature loess soil, as Holdrege silt loam.

Percentage distribution of weight of roots of buffalo grass was remarkably uniform in the three soil types in loess. Variations were from 68.6 to 70.6 percent at 0 to 6 inches and even less in the second- and thirdfoot depths.

Percentage of roots of big bluestem in the A horizon of the several soil types varied almost directly with its depth from 78.0 in a 7-in. horizon to 89.8 in one 20 inches deep. A similar relationship was found in both little bluestem and side-oats grama. In bluegrass the percentages were $81.7,92.3$, and 96.9 in A horizons 7, 13, and 20 inches deep, respectively.

Western wheat grass in the shallowest (0-5 in.) A horizon had the smallest percentage of roots (55.2). In the deepest (0-12 in.) the root-weight was 65.0 percent.

Percentage of roots of blue grama in the A horizon increased directly with the depth of this layer from 89.2 (0-7 in.) to 97.5 (0-20 in.).

Regardless of a 12-inch fill in Wabash silt loam this layer had nearly the same percentage of roots of buffalo grass (81.4) as the 12-inch A horizon of Holdrege silt loam. But the deeper A horizon (0-17 in.) in Sherman silt loam contained 89.5 percent of the entire root system.

\section{LITERATURE CITED}

Albertson, F. W. 1937. Ecology of mixed prairie in west central Kansas. Ecol. Monog. 7: 481-547.

Hanson, H. C., \& W. Whitman. 1938. Characteristics of major grassland types in western North Dakota. Eeol. Monog. 8: 57-114.

Jean, F. C., \& J. E. Weaver. 1924. Root behavior and crop yield under irrigation. Carnegie Inst. Wash., Pub. 357.

Nedrow, W. W. 1937. Studies on the ecology of roots. Ecology 18: 27-52.

Shively, S. B., \& J. E. Weaver. 1939. Amount of underground plant materials in different grassland climates. Univ. Neb. Cons. and Surv. Div. Bul. 21.
Sperry, T. M. 1935. Root systems in Illinois prairie. Ecology 16: 178-202.

Thorp, J. 1948. How soils develop under grass. Yearbook of Agr. Pp. 55-66. U. S. Dept. Agr.

Weaver, J. E. 1919. The ecological relations of roots. Carnegie Inst. Wash., Pub. 286.

1920. Root development in the grassland formation. Carnegie Inst. Wash., Pub. 292.

1926. Root development of field crops. MeGraw-Hill Book Co., Ine., New York.

1942. Competition of western wheat grass with relict vegetation of prairie. Amer. Jour. Bot. 29: 366-372. 1943. Replacement of true prairie by mixed prairie in eastern Nebraska and Kansas. Ecology $24: 421-434$.

1947. Rate of decomposition of roots and rhizomes of certain range grasses in undisturbed prairie soil. Ecology 28 : 221-240.

Weaver, J. E., \& F. W. Albertson. 1943. Resurvey of grasses, forbs, and underground plant parts at the end of the great drought. Ecol. Monog. 13: 63-117.

Weaver, J. E., \& W. E. Bruner. 1927. Root development of vegetable crops. McGraw-Hill Book Co., Inc., New York.

1948. Prairies and pastures of the dissected loess plains of central Nebraska. Ecol. Monog. 18: 507-549.

Weaver, J. E., \& R. W. Darland. 1947. A method of measuring vigor of range grasses. Ecology 28 : 146-162.

Weaver, J. E., \& W. W. Hansen. 1941. Regeneration of native midwestern pastures under protection. Univ. Neb. Cons. and Surv. Div. Bul. 23.

Weaver, J. E., \& G. W. Harmon. 1935. Quantity of living plant materials in prairie soils in relation to runoff and soil erosion. Univ. Neb. Cons. and Surv. Div. Bul. 8.

Weaver, J. E., V. H. Hougen, \& M. D. Weldon. 1935. Relation of root distribution to organic matter in prairie soil. Bot. Gaz. $96: 389-420$.

Weaver, J. E., F. C. Jean, \& J. W. Crist. 1922. Development and activities of roots of crop plants. Carnegie Inst. Wash., Pub. 316.

Weaver, J. E., \& E. Zink. 1946. Annual inerease of underground materials in three range grasses. Ecology 27: $115-127$

1946a. Length of life of roots of ten species of perennial range and pasture grasses. Plant Physiol. 21: 201-217. 